2013

\title{
Towards a New Democratic Africa: The African Charter on Democracy, Elections and Governance
}

Stacy-Ann Elvy

New YorkLaw School, selvy@nyls.edu

Follow this and additional works at: http://digitalcommons.nyls.edu/fac_other_pubs Part of the Constitutional Law Commons, and the International Law Commons

\section{Recommended Citation}

27 Emory Int'l L. Rev. 41 (2013)

This Article is brought to you for free and open access by the Faculty Scholarship at DigitalCommons@NYLS. It has been accepted for inclusion in Other Publications by an authorized administrator of DigitalCommons@NYLS. 


\title{
TOWARDS A NEW DEMOCRATIC AFRICA: THE AFRICAN CHARTER ON DEMOCRACY, ELECTIONS AND GOVERNANCE
}

\author{
Stacy-Ann Elvy*
}

\begin{abstract}
The African Charter on Democracy, Elections and Governance ("ADC") recently entered into force on February 15, 2012. The main goal of the $A D C$ is the encouragement and promotion of democracy and human rights on the African continent. The ADC is the first binding regional instrument adopted by member states of the African Union ("AU") that attempts to comprehensively address all of the elements necessary for the establishment of liberal democracies. The ADC also contains a number of expansive provisions regarding unconstitutional changes of government. For instance, the ADC is the first legal instrument adopted by member states of the $A U$ that acknowledges that an unconstitutional change of government includes any amendments to the constitution or legal instruments of a member state that infringe on the principles of democratic change of government. Many African heads of state have amended the constitutions of their respective countries to retain power. Additionally, many Latin American and African countries continue to struggle to establish viable long-term liberal democracies. In 2007, the $A U$ and the Organization of American States ("OAS") participated in an inter-regional conference entitled the "OAS-AU Democracy Bridge," aimed at promoting democracy and good governance in the Americas and Africa. Given the express commitment of the $A U$ and the $O A S$ to the promotion of liberal democracies, this Article critiques the ADC by providing a comparative analysis of both the Inter-American Democratic Charter ("ODC") and the $A D C$ and identifies areas in which the ADC may be strengthened. Despite the expansive provisions contained in the ADC and in light of the ineffectiveness of earlier instruments adopted by the $A U$ to promote democracy, this Article contends that in order to take concrete steps toward achieving democracy in
\end{abstract}

* Associate Professor of Law, New York Law School (J.D., Harvard Law School; B.S., Cornell University). I am grateful to Dean Penelope Andrews, Professor Molly Land, Professor Sudha Setty, Professor Bridgette Baldwin, and Professor Cindy Galway Buys for their invaluable comments on this Article. I would also like to thank my research assistants Olivia Weil, Brittney Sharp, and Alexis Barkis. 
Africa, the AU must not only obtain widespread state ratification of the ADCwith the added challenge of using and enforcing its provisions in the face of entrenched practices to the contrary-but the AU must also heed the lessons learned from the OAS' attempts to use the ODC to foster democracy in Latin America.

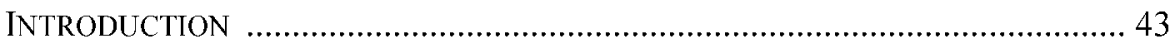

I. THEORIZING DEMOCRACY …............................................. 48

II. THE AU'S PRIOR EFFORTS TO PROMOTE DEMOCRACY IN AFRICA ..... 55

A. African Charter and Constitutive Act ........................................ 55

B. Lomé Declaration .................................................................. 59

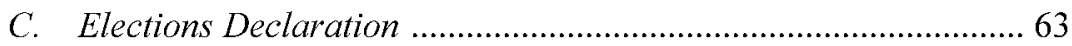

D. Corruption Convention ....................................................... 67

E. NEPAD Democracy Declaration .............................................. 72

F. Colonialism and Democracy in Africa ...................................... 77

III. THE AFRICAN DEMOCRATIC CHARTER AND THE OAS DEMOCRATIC CHARTER ................................................................ 80

A. Comparative Analysis of the OAS Democratic Charter and the African Democratic Charter ................................................ 81

1. Democracy as a Legal Right ......................................... 82

2. Unconstitutional Changes of Government and Sanctions ...... 85

3. Extradition ....................................................................... 94

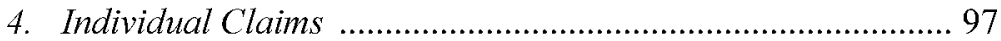

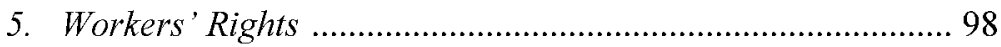

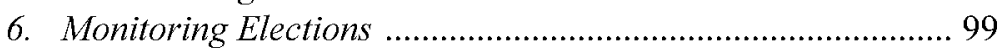

7. General Enforcement Mechanism ..................................... 102

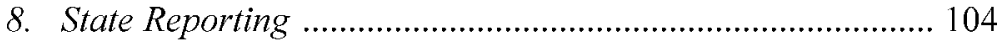

B. The OAS Democratic Charter in Action: Lessons for the AU ... 105

1 Venezuela ...................................................................... 106

2. Honduras .......................................................................... 107

3. Nicaragua ....................................................................... 111

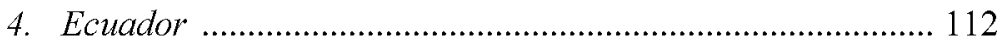

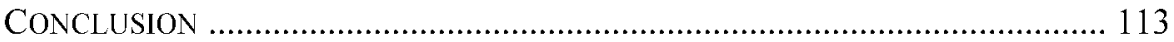




\section{INTRODUCTION}

On January 30, 2007, member states of the African Union ("AU") adopted the African Charter on Democracy, Elections and Governance ("ADC"). However, the ADC only recently entered into force on February 15, 2012. ${ }^{2}$ The main goal of the ADC is the encouragement and promotion of democracy and human rights in Africa. ${ }^{3}$ With the exception of a few A frican countries such as Mauritius, Ghana, South Africa, and Botswana, most African countries generally rank poorly on leading international democracy indices. ${ }^{4}$ Thus, improvement in this area is sorely needed. Zimbabwe is an example of an African country that continues to struggle with achieving a viable democracy. Zimbabwean President Robert Mugabe has controlled Zimbabwe for the last thirty years. ${ }^{5}$ In the 2008 elections Mugabe accused his political opponents, the Movement for Democratic Change, ${ }^{6}$ of treason and Mugabe placed significant restrictions on fundamental human rights that are central to maintaining democratic order, including freedom of expression and freedom of the press.

1 African Charter on Democracy, Elections and Governance arts. 2-4, Jan. 30, 2007, http://www.au.int/ en/sites/default/files/AFRICAN_CHARTER_ON_DEMOCRACY_ELECTIONS_AND_GOVERNANCE.pdf [hereinafter ADC]. This Article uses the term "Africa" to refer to the African countries that are member states of the AU. For a list of AU member countries, see Ratification Status of the ADC, infra note 2.

2 African Union, List of Countries Which Have Signed, Ratified/Acceded to the African Charter on Democracy, Elections and Governance (Jan. 17, 2012), http://www.chr.up.ac.za/images/files/news/news_2012/ african_charter_democracy_governance.pdf [hereinafter Ratification Status of the ADC].

3 ADC, supra note 1.

4 See ECONOMist Intelligence Unit, Democracy Index 2011: Democracy Under Stress 2-8 tbl.2 (2011), available at $\mathrm{http} / /$ www.sida.se/Global/About\%20Sida/Så\%20arbetar\%20vi/EIU_Democracy_Index_ Dec2011.pdf (ranking Mauritius as twenty-fourth, South Africa as twenty-eighth, and Botswana as thirty-third in its worldwide democracy index, with the next highest rank among African states being Mali at sixty-third); see also Arch Puddington, Freedom in the World 2013: Democratic Breakthroughs in the Balance, FreEdom HOUSE 14-18 (2013), http://www.freedomhouse.org/sites/default/files/FIW\%202013\%20Booklet \%20-\%20for $\% 20$ Web.pdf (describing the "Freedom Status" of Ghana, Mauritius, Botswana, and South Africa as "Free" with relatively high ranks in political rights and civil liberties); Daniel Kaufmann \& Aart Kraay, Government Indicators: Where Are We, Where Should We Be Going? 41 fig.2 (World Bank, Policy Research Working Paper No. 4370, 2007), available at http://info.worldbank org/governance/wgi/pdf/wps4370.pdf (showing that Botswana is successfully combating corruption, especially when compared to other African states).

5 See lauren Ploch, Cong. Research Serv., Rl34509, Zimbabwe: 2008 Elections and IMPLICATIONS FOR U.S. POLICY 1 (2008).

6 Our History, Movement fOR Democratic Change (Nov. 19, 2009), http://www.mdc.co.zw/index. php/our-party/our-history.html.

7 LaUren Ploch, Cong. Research Serv, Rl32723, Zimbabwe: Background 19-21 (2010) (describing a campaign of violence staged against the Movement for Democratic Change and its supporters during a 2008 runoff presidential election); see also HUMAN RIGHTS WATCH, WORLD REPORT 2012, at 200-01 (2012), available at http:/www.hrw.org/sites/default/files/reports/wr2012.pdf; PATTI MCCRACKEN, INSULT LAwS: Insulting to Press Freedom 86 (Ronald Koven ed., 2012), available at http://www. freedomhouse. org/sites/default/files/Insult\%20Law\%20Report.pdf. 
Given the lack of democratic practices in most African countries, the following question remains: can the $\mathrm{ADC}$ truly promote democracy in Africa? This Article addresses this question by conducting a comparative analysis of similar instruments in other regions and earlier instruments adopted by the AU to promote democracy.

The ADC contains a number of expansive provisions on unconstitutional changes of government. For instance, the ADC is the first regional instrument adopted by member states of the AU that acknowledges that an unconstitutional change of government includes any amendments to the constitution or legal instruments of a member state that infringe on the principles of democratic change of government. ${ }^{8}$ Many African heads of state have amended the constitutions of their respective countries to keep themselves in power. For example, Cameroonian President Paul Biya has been in power since 1982; because Cameroon's constitution was amended to eliminate a two-term-presidential limit, permitting Biya to continue to run for re-election and remain in power. ${ }^{9}$ Similarly, Chadian President Idriss Déby was elected to a third presidential term after a constitutional referendum eliminated presidential limits, ${ }^{10}$ and Ugandan President Yoweri Museveni was re-elected to a third term after the Ugandan constitution was amended in 2005 to abolish presidential term limits. ${ }^{11}$

Many member states of the AU refused to ratify the ADC because of the charter's expansive provisions regarding the promotion of democracy. ${ }^{12}$ Despite the reluctance on the part of a majority of African states to ratify the ADC, a few brave states have executed and ratified the charter. To date, the

8 ADC, supra note 1, art. 23(5).

9 ORg. For ECON. CO-Operation \& Dev. [OECD], InTERNATIONAL Drivers of CoRruption 44 (2012), available at http://www.oecd.org/development/governance-development/49263997.pdf; Cameroon: Freedom in the World 2012, FREEDOM HOUSE, http://www.freedomhouse.org/report/freedom-world/2012/ cameroon (last visited Mar. 20, 2013).

10 Daniel N. Posner \& Daniel J. Young, The Institutionalization of Political Power in Africa, $18 \mathrm{~J}$. DEMOCRACY 126, 133-34 (2007); Chad: Freedom in the World 2012, FREEDOM HOUSE, http:/www. freedomhouse org/report/freedom-world/2012/chad (last visited Mar. 20, 2013).

11 Posner \& Young, supra note 10, at 133-34; Uganda: Freedom in the World 2012, FreEdom House, http://www.freedomhouse org/report/freedom-world/2012/chad (last visited Mar. 20, 2013).

12 AU Turns down Democracy Charter, BBC News (June 30, 2006), http://news.bbc.co.uk/2/hi/africa/ 5132692.stm. To date, the following countries have not ratified the ADC: Algeria, Angola, Benin, Botswana, Central African Republic, Cape Verde, Cote d'Tvoire, Comoros, Congo, Djibouti, Democratic Republic of Congo, Egypt, Equatorial Guinea, Eritrea, Gabon, Gambia, Kenya, Libya, Liberia, Madagascar, Mali, Malawi, Mozambique, Mauritius, Namibia, Sahrawi Arab Democratic Republic, Senegal, Seychelles, Somalia, Sao Tome \& Principe, Sudan, Swaziland, Tanzania, Togo, Tunisia, Uganda, and Zimbabwe. Ratification Status of the ADC, supra note 2. 
following fifteen member states of the AU have ratified the ADC: Mauritania, Rwanda, Guinea, Ethiopia, Chad, Niger, Sierra Leone, Ghana, Guinea-Bissau, Burkina Faso, South Africa, Nigeria, Lesotho, Zambia, and Cameroon. ${ }^{13}$ The newly effective ADC has the potential to promote democracy, at least in the fifteen states that have ratified the charter. Promotion of democracy in ratifying states may serve as a model to states, such as Zimbabwe, that have long suffered under the leadership of presidents who refuse to relinquish power. ${ }^{14}$

While Cameroon and Burkina Faso have ratified and executed the ADC; both countries are subject to semi-authoritarian rule. ${ }^{15}$ Cameroonian President Paul Biya and Burkinabe President Blaise Camporé have controlled their respective countries for at least twenty years. ${ }^{16}$ In 2013 , Cameroon held its first senatorial elections, but President Biya's party retained "total control of the newly-created 100-seat Senate," winning fifty-six of seventy-contested seats, in addition to the thirty senatorial seats appointed by the president under the constitution. ${ }^{17}$ As such, it is unlikely that mere state ratification of the ADC will lead to true democracy in Cameroon. Ultimately, this Article argues that democracy in Africa will not be achieved simply through the adoption of a new regional instrument. To take concrete steps toward achieving democracy in Africa, the AU must not only obtain widespread state ratification of the ADC - with the added challenge of using and enforcing its provisions in the face of entrenched practices to the contrary-but the $A U$ must also heed the lessons learned from the Organization of American States' ("OAS") attempts to use the Inter-American Democratic Charter ("ODC") to foster democracy in Latin America.

13 Ratification Status of the ADC, supra note 2.

14 PLOCH, supra note 5, at 1; PLOCH, supra note 7, at 23

15 Ratification Status of the ADC, supra note 2; see also BERTELSMANN STIFTUNG, BTI 2012: CAMEROON COUnTRY RePORT 8 (2012), available at $\mathrm{http}: / /$ www.bti-project.org/uploads/tx_jpdownloads/BTI_ 2012_Cameroon.pdf. Mathieu Hilgers, Evolution of Political Regime and Evolution of Popular Political Representations in Burkina Faso, 4 AFr. J. POL. SCI. \& INT'L REL. 350, 350 (2010).

16 Examining the U.S. Policy Response to Entrenched African Leadership: Hearing Before the Subcomm. on African Affairs of the S. Comm. on Foreign Relations, 112th Cong. 39, 43 n.5 (2012) (statement of Christopher Fomunyoh, Senior Associate \& Regional Director for Central and West Africa, National Democratic Institute); see also Burkina Faso: Freedom in the World 2012, FREEDOM House, http://www. freedomhouse org/report/freedom-world/2012/burkina-faso (last visited Mar. 20, 2013); Cameroon: Freedom in the World 2012, supra note 9.

17 Party of Longtime Cameroon Ruler Paul Biya Wins Landslide in Maiden Senate Vote, FOXNEWS.COM, Apr, 30, 2013, http://www.foxnews.com/world/2013/04/30/party-longtime-cameroon-rulerpaul-biya-wins-landslide-in-maiden-senate-vote/\#ixzZ2Si66c7Qp. 
Prior to the adoption of the ADC, AU member states adopted a series of instruments to facilitate the implementation of democratic norms in African states. For instance, both the Constitutive Act of the AU ("Constitutive Act") and the African Charter on Human and Peoples' Rights ("African Charter") contain provisions aimed at promoting good governance and respect for human rights. The Declaration on the Principles Governing Democratic Elections in Africa ("Elections Declaration") and the AU Convention on Preventing and Combating Corruption ("Corruption Convention") aimed to promote free and fair democratic elections and eliminate corruption. All of these instruments eventually failed to lead to widespread democracy in Africa.

In light of the AU's history of adopting instruments that have failed to achieve their true purpose, is the ADC simply another instrument that is doomed to fail? To answer this question and determine the potential efficacy of the ADC, this Article critiques the prior instruments adopted by the AU to promote democracy and identifies the reasons for the ineffectiveness of those instruments. This Article contends that those prior instruments did not successfully achieve widespread democracy in Africa for a number of reasons, including the AU's failure to: (1) include effective enforcement provisions; (2) adequately use enforcement provisions; and (3) obtain widespread state ratification of binding instruments. This Article posits that when compared to prior instruments adopted by the $\mathrm{AU}$ to promote democracy, the ADC has the potential to succeed where these other instruments have failed, subject to effective use and enforcement by the $\mathrm{AU}$.

In 2007, the AU and the OAS participated in an inter-regional conference entitled the "OAS-AU Democracy Bridge," aimed at promoting democracy and good governance in the Americas and Africa. ${ }^{18}$ Given the express commitment of both organizations to the promotion of democracy, this Article critiques the ADC by providing a comparative analysis of both the ODC and the ADC. Through this comparative analysis, this Article identifies several areas in which the $\mathrm{ADC}$ could be strengthened. For instance, this Article argues that the $\mathrm{ADC}$ should be revised to remove the requirement that democratic initiatives must fail prior to the suspension of state membership in

18 Democracy Bridge: Multilateral Regional Efforts for the Promotion and Defense of Democracy in Africa and America, July 10-12, 2007, at 15-16 (2007), available at http://www.oas.org/sap/docs/BRIDGE 20-12-07_completo.pdf; see also Declaration of Intent Between the Commission of the African Union (AUC) and the General Secretariat of the Organization of American States (GS/OAS), AU-OAS, done July 10, 2007, http://www.oas.org/dil/AgreementsPDF/42-2007_Declaration_of_Intent_SG-OEA_Commission_of_the_ African Union.PDF. 
the $\mathrm{AU}$; to establish democracy as a legal right to which all Africans are entitled; to provide guidance to member states on appropriate presidential term limits; to establish the chargeable offenses which may be brought against perpetrators of unconstitutional changes of government; and to establish the right of individuals and NGOs to bring complaints regarding violations of the ADC before the AU, the appropriate African court, or the AU Commission on Human and Peoples' Rights ("AU Human Rights Commission"). It is important to acknowledge that the suggested changes to improve the ADC may not occur quickly, if at all, because some AU member states may be unwilling to support effective enforcement measures or grant additional rights to their citizens. However, the purpose of this Article is to facilitate discussions on what makes for a strong regional instrument on democracy and to chart the course for future work in this area in order to promote democracy in Africa. Moreover, given the recent military coup in Egypt it is evident that in addition to having a solid regional charter on democracy, sufficient local conditions, such as respect for the constitution, the rule of law and minority rights, and the elimination of excessive military power, must exist in order to establish longterm viable democracies in Africa. ${ }^{19}$

This Article also addresses the serious issues encountered by the OAS in its use of the ODC to resolve political crises in Latin America, with the hope that the $A U$ may avoid similar mistakes when using the ADC. For instance, the 2002 Venezuelan crisis, as discussed in Part III, indicates that ratifying member countries may resist the ability of the $\mathrm{AU}$ to dispatch electoral observer missions. The AU must be ready to use the enforcement provisions of the ADC against non-compliant states. The problems encountered by the OAS in its implementation of the ODC also illustrate that the adoption of a democratic charter, without more, will not automatically lead to widespread democracy.

The main goal of the ADC is to promote democracy in A frican countries. ${ }^{20}$ But how does one define and measure democracy? Much has been written on the meaning of the term "democracy." Political scientists have developed

19 Egypt is not bound by the provisions of the ADC because Egypt has not yet ratified the charter. Ratification Status of the ADC, supra note 2. President Mohammed Morsi, who was freely elected in 2012, was removed from power by the Egyptian military in July, 2013. African Union Communique of the 384th Meeting of the Peace and Security Council, paras. 3-6, Doc. PSC/PR/COMM/ (CCCLXXXIV) (Jul. 5, 2013). To date, the AU has labeled the recent crisis in Egypt as an unconstitutional change of government and has suspended Egypt's membership in the AU. $l d$.

20 ADC, supra note 1, arts. 2-4. 
different approaches to defining and measuring democracy and have also recognized the existence of several distinct categories of democracy. This Article contends that the ADC is aimed at establishing liberal democracies with a representative form of government. As such, this Article's critique of the ADC is primarily focused on the ability of the charter - through effective enforcement and use by the AU-to promote liberal democracies in the member states of the AU.

This Article proceeds as follows: Part I of this Article addresses the different approaches to defining democracy and the different types of democracy recognized by political scientists. Part I posits that the AU has elected to promote liberal democracies, as evidenced by the provisions of the ADC, because radical, guided, consociational, and socialist democracies arguably have led to failed African states, human rights will be more adequately protected in strong liberal democracies, and the liberal form of democracy has been the most economically successful form of democratic government. Part II of this Article discusses the AU's earlier efforts to promote democracy in Africa, including the African Charter; the Constitutive Act; the Lomé Declaration adopted by the Organization of African Unity ("OAU"), the predecessor of the AU; the Elections Declaration; the Corruption Convention; and the New Partnership for Africa's Development ("NEPAD") Declaration on Democracy, Political, Economic and Corporate Governance ("NEPAD Democracy Declaration"). Then, this Article analyzes and determines why these prior efforts were unsuccessful in achieving widespread democracy in Africa, and argues that these failures evidence that effective use and enforcement of the ADC is needed to promote democracy. Part III critiques the provisions of the ADC and compares the ADC to the ODC. This Part identifies areas in which the ADC may be strengthened and contends that while the provisions contained in the $\mathrm{ADC}$, combined with effective enforcement by the $\mathrm{AU}$, could lead to the promotion of democracy in Africa, the AU should heed the lessons learned from the OAS' attempts to use the ODC in Latin America. This Article concludes by pointing the way forward.

\section{THEORIZING DEMOCRACY}

Through the adoption of the ADC, the AU has appropriately used a multilayered approach to measuring democracy in Africa. Further, the ADC provides evidence that the $\mathrm{AU}$ has elected to promote liberal democracies with a representative form of government. It is likely that the AU's decision to 
foster liberal democratic ideals will promote the protection of human rights in African countries, provided that the AU effectively enforces the ADC.

According to Charles Tilly, there are four main approaches to defining and measuring democracy. ${ }^{21}$ First, the constitutional approach to democracy focuses on the legal form and structure of the government, as well as the codified laws of a country relating to political activity. ${ }^{22}$ Second, the substantive approach to democracy defines a regime as democratic to the extent that the regime promotes "human welfare, individual freedom, security, equity, social equality, public deliberation, and peaceful conflict resolution." 23 Third, the procedural approach to democracy focuses on governmental actions during elections. ${ }^{24}$ To the extent that governmental elections are noncompetitive, proponents of the procedural approach contend that such governments are not democratic. ${ }^{25}$ Tilly states the Freedom House Democracy Index relies heavily on the procedural approach to democracy in determining whether a country is an electoral democracy. ${ }^{26}$ Fourth, a process-oriented approach to defining democracy focuses on "some minimum set of processes that must be continuously in motion for a situation to quality as democratic."27 According to Tilly, Robert A. Dahl adopted a process-based approach to defining democracy, which focuses on effective participation, voting equality, and the inclusion of adult citizens, among other factors. ${ }^{28}$ Tilly then posits that "a regime is democratic to the degree that political relations between the state and its citizens feature broad, equal, protected and mutually binding consultation." 29

There are drawbacks to adopting a singular approach to defining democracy. For instance, a constitutional approach to defining democracy fails to take into account the potential discrepancies between the rights established

\footnotetext{
21 Charles Tilly, Democracy 7 (2007).

22 Id. ("Within democracies, ... we can distinguish between constitutional monarchies, presidential systems, and parliament-centered arrangements, not to mention such variations as federal versus unitary structures.").

23 Id. at 8.

$24 \mathrm{Id}$

25 Id. ("If elections remain a non-competitive sham[,] . . procedural analysts reject them as criteria for democracy. But if they actually cause significant governmental changes, they signal the procedural presence of democracy.").

26 Id.

27 Id. at 9

28 Id. (quoting ROBERT A. DAHL, ON DEMOCRACY 37-38 (1998))

29 Id. at 13-14 (emphasis omitted). Tilly further states that "[d]emocratization means net movement toward broader, more equal, more protected, and more binding consultation." Id. at 14 .
} 
by the constitution and laws of a country, and the ways in which such rights may be encroached upon by governments in practice. ${ }^{30}$ Similarly, a substantive approach to defining democracy presents a problem concerning tradeoffs among competing principles, such as: "If a given regime is desperately poor but its citizens enjoy rough equality, should we think of it as more democratic than a fairly prosperous but fiercely unequal regime?"31 Given the vastness and cultural diversity of the African continent, a singular approach to measuring and defining democracy is not practical. A comprehensive approach, which combines all four of the approaches described by Tilly, should be used in the African context to evaluate African democracies.

The ADC reflects the AU's adoption of a multi-layered approach to measuring and defining democracy. With respect to the constitutional approach, the ADC contains provisions aimed at ensuring the supremacy of the constitution and discouraging unconstitutional changes of government. ${ }^{32}$ The ADC also requires member states to enact legislation to protect and ensure political participation by citizens. ${ }^{33}$ The ADC also contains provisions that safeguard individual freedoms and social equality, all of which are factors central to a substantive approach to measuring democracy. ${ }^{34}$ With respect to the procedural approach to measuring democracy, the ADC contains a plethora of rules that regulate governmental practices, including competitive elections. ${ }^{35}$

Political scientists have also distinguished between three main theories of public political participation within democracies: direct, deliberative, and representative political participation. Deliberative political participation is characterized by broad, informed, deliberative, and credible public participation by citizens. ${ }^{36}$ Put differently, "Deliberative democracy is a theoretical account of proper democratic decision-making[,] ... hold[ing] that the legitimacy of decisions can be increased if such decisions are preceded by authentic deliberation., ${ }^{, 37}$ Direct political participation refers to a political process through which citizens vote directly on laws rather than simply voting

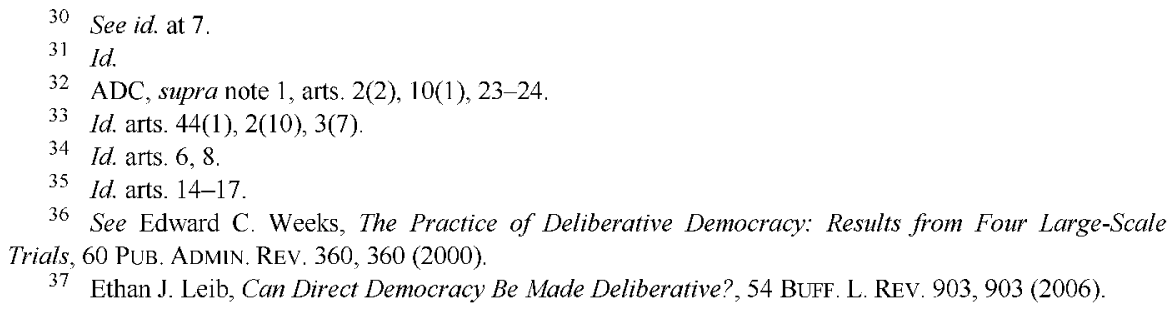


on members of the legislative branch. ${ }^{38}$ In contrast, in a representative form of government:

Citizens ... are twice removed from legislation. First, they do not deliberate and vote directly on legislation. Rather they elect assemblies that enact such legislation in their stead. Second,... citizens do not vote directly for assemblies. Rather they vote for individual candidates, with the candidates receiving the most votes elected. $^{39}$

The OAS has stated that its member states must respect the essential elements of a representative democracy, as well as promote conditions necessary for the exercise and protection of a representative form of government, as required by the ODC. ${ }^{40}$

In addition to the different approaches used to define the term democracy and the different theories used to measure political participation in democracies, Robert Pinkney contends that there are different types of democracies, with the liberal democratic form of government being the most prevalent. $^{41}$

In a liberal democracy, there are "[c]hecks and balances to prevent tyranny of the majority" or powerful minorities, and the state acts as a "[r]eferee" between competing groups. ${ }^{42}$ The main objective of a liberal democracy is the "[r]epresentation and protection of diverse interests," and the rights of citizens are safeguarded by the constitution; however, under a liberal democracy unequal distribution of resources may lead to political domination by the elite. ${ }^{43}$ A representative form of government is an essential aspect of liberal democracies. In fact, it has been argued that representative political

\footnotetext{
38 John G. Matsusaka, Direct Democracy Works, 19 J. ECON. PERSP. 185, 187 (2005).

39 Jean-Pierre Benoit \& Lewis A. Kornhauser, Social Choice in a Representative Democracy, 88 AM. POL. SCI. REV. 185, 185 (1994) (emphasis omitted).

40 C.J.I. Res. 159 (LXXV-O/09), para. 2, O.A.S. Doc. CJI/RES. 159 (LXXV-O/09) (Aug. 11, 2009).

41 Robert Pinkney, Democracy in the Third World 8 tbl.1.1 (2d ed. 2003). Pinkney describes the following five types of democracies: radical democracies, guided democracies, liberal democracies, socialist democracies, and consociational democracies. Id. at 10-15. Some scholars contend that there are instances in which some of the characteristics of each type of democracy may be found in a single country. E.g., SAMUEL Ebow Quatnoo, TRANSITIONS AND CONSOLIDATION OF DEMOCRACY IN AFRTCA 17 (2000). For example, Mauritius contains elements of both liberal and consociational democracies. QUAINoO, supra, at 17.

42 PINKNEY, supra note 41, at 8 tbl.1.1; accord id. at 12

43 Id. at 8-9 tbl.1.1; accord $i d$. at 12. Pinkney posits that most liberal democracies are characterized by wealthy elites who dominate the political process and who are numerically overrepresented in the executive and legislative branches of government. $I d$. at 12
} 
participation is "at the heart of the 'new science of politics' designed to make liberal democracy possible." ${ }^{44}$

At the end of the Cold War, liberal democracy became the main form of democracy and the prestige and value accorded to liberal democratic ideals increased tremendously. ${ }^{45}$ Once the Cold War ended, " $[t]$ he United States, excited by the seeming triumph of Western liberal democracy, asserted [a] new wave of [liberal] democracy before the Organization of American States (O.A.S.) in $1989 \ldots ., 46$ Similarly, Benjamin Barber contends that liberal democracies are the "dominant modern form of democracy, [and such democracies have] informed and guided several of the most successful and enduring governments the world has known, not least among them that of the United States."47

There are elements of representative, direct, and deliberative political participation within the American liberal democratic system. For instance, Ethan Leib contends that "direct democracy exists in twenty-seven states [in the United States] in the form of the referendum and the initiative., 48 Additionally, many have argued that even representative democracies, and therefore liberal democracies, are deliberative in nature to the extent that citizens inform their elected representatives of their interests and views. ${ }^{49}$ It has also been suggested that the OAS attempted to enshrine liberal democratic governance in the Americas through adoption of the ODC. ${ }^{50}$

\footnotetext{
44 Rainer Knopff, Populism and the Politics of Rights: The Dual Attack on Representative Democracy, 31 CANAdian J. POL. SCl, 683, 685 (1998).

45 Andrew Coleman \& Jackson Maogoto, Democracy's Global Quest: A Noble Crusade Wrapped in Dirty Reality?, 28 Suffolk TranSNAT'L L. Rev. 175, 175-77 (2005).

46 Id.

47 Benjamin R. Barber, Strong Democracy: Participatory Politics for a NeW Age 3 (20th anniversary ed. 2003). Despite the dominance of liberal democracies, Barber critiques liberal democracies and posits that because liberal democracies have a perceived monopoly on the future of democracy, liberal democracy limits the "alternatives apparent to those seeking other legitimate forms of politics but leaves Americans themselves with no standard against which to measure their own liberal politics and with no ideal by which to modify them, should they wish to do so." Id.

48 Leib, supra note 37, at 904 (citing Julian N. Eule, Judicial Review of Direct Democracy, 99 Y ALE L.J. 1503 app. A, at $1587-89(1990))$.

49 E.g., Mark Button \& Kevin Mattson, Deliberaive Democracy in Practice: Challenges and Prospects for Civic Deliberation, 31 PoLITY 609, 609 (1999)

50 Ray Walser, Time for U.S. Leadership at the Organization of American States, HERITAGE FOUnD.: WEBMEMO 1 (June 2, 2011), http//thf_media.s3.amazonaws.com/2011/pdf/wm3276.pdf; see also DAVTD P. Forsythe, HuMAN Rights AND COMPARATIVE FOREIGN POLICY 294 (2000) (contending that the Organization of American States ("OAS") has advocated for the establishment of liberal democracies in Latin America without the use of force).
} 
The ADC aims toward establishing liberal democracies with a representative form of government in $\mathrm{AU}$ member states. A representative form of government is a core concept of liberal democracies. ${ }^{51}$ Free and fair periodic elections by universal and equal suffrage, respect for the rule of law, respect for human rights, and political participation by citizens are central elements of all liberal democracies. ${ }^{52}$ The ADC facilitates the promotion of these liberal ideals. For instance, the ADC provides that the objective of the $\mathrm{ADC}$ is to promote "the universal values and principles of democracy and respect for human rights ... [as well as] the necessary conditions to foster citizen participation." ${ }^{53}$ As previously noted, the liberal form of democratic government is the most universally prevalent form of democracy. ${ }^{54}$ The ADC also provides that one of the objectives of the charter is to "[p]romote the holding of regular free and fair elections to institutionalize legitimate authority of representative government as well as democratic change of governments." 55 Checks and balances, separation of power, and equality before the law are also key characteristics of liberal democracies. ${ }^{56}$ The ADC recognizes equal protection as a "fundamental precondition for a just and democratic society." The ADC also obligates member states to guarantee the separation of powers among different branches of government and protect the independence of the judiciary. ${ }^{58}$

African countries have a long history of unsuccessfully experimenting with different forms of democracy. For instance, radical democracies have failed in countries such as Ghana under Kwame Nkrumah's rule, and Guinea under Sékou Touré's rule. ${ }^{59}$ Tanzania in the 1980s may have qualified as a socialist democracy. ${ }^{60}$ Scholars have argued that the consociational form of democracy

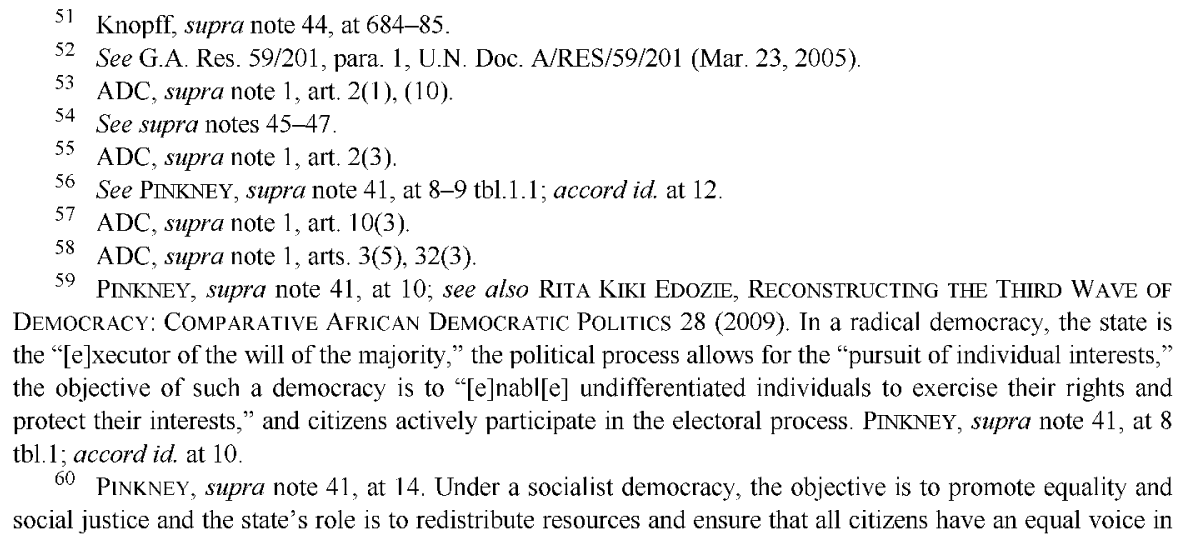
the "[e]xecutor of the will of the majority," the political process allows for the "pursuit of individual interests," the objective of such a democracy is to "[e]nabl[e] undifferentiated individuals to exercise their rights and protect their interests," and citizens actively participate in the electoral process. PINKNEY, supra note 41, at 8

60 PINKNEY, supra note 41, at 14. Under a socialist democracy, the objective is to promote equality and social justice and the state's role is to redistribute resources and ensure that all citizens have an equal voice in tbl. 1 ; accord id. at 10 . 
has been unsuccessful in African countries such as Angola, Liberia, Somalia, and Ethiopia. ${ }^{61}$ Arguably, Zambia under Kenneth Kaunda and Kenya under Daniel Arap Moi serve as examples of failed guided democracies. ${ }^{62}$ The failure of radical, guided, socialist, and consociational governments in Africa provides evidence that these forms of democracy are not viable options, in the longterm, for most African countries. In contrast, Mauritius and Botswana, as liberal democracies, rank highly on a number of international democracy indices $^{63}$ and Mauritius has been acknowledged as having "one of the best records in Africa for democratic practice and institutions . . .., "64

It is likely that the prevalence of A frican countries with failed forms of radical, guided, socialist, and consociational democracies, along with international pressure and the success of liberal democracies have influenced the AU to promote a liberal form of democratic government. Despite the danger of unequal distribution of resources that may be created under a liberal form of democratic government, some scholars contend that "liberal

the political process by decreasing the inequality in resources and wealth. $I$ d. at 8 tbl.1.1; accord id. at 13 . Pinkney posits that coercion may be necessary to achieve the required objectives of a socialist democracy. $I d$ at 13 .

61 E.g., René Lemarchand, Consociationalism and Power Sharing in Africa: Rwanda, Burundi, and the Democratic Republic of the Congo, 106 AFR. AFF. 1, 2 (2007). René Lemarchand contends that most observers would agree that "much of the [African] continent is a graveyard of consociational experiments," but Burundi presents a "promising case" for the success of African consociational democracies. Id. In a consociational democracy, the political process is characterized by diverse interests and identities and the state acts as a referee to prevent intergroup conflict by attempting to unite leaders of all major groups to promote a consensus between diverse groups. PINKNEY, supra note 41, at 14 . Consociational democracies may reinforce social divisions, as they promote citizen participation through the use of constituent groups and group leaders. Id. at 9 tb1.1.1; accord id. at 14. Examples of sustained consociational democracies include Belgium and Holland. Id. at 15 . Scholars have questioned whether a consociational form of democracy is a viable long-term option for African countries, as "[t]he normally accepted requirements of the legitimacy of ruling elites-respect for well-established institutions and procedures, a spirit of compromise, and an overarching sense of national loyalty - may be less strongly developed in third world countries." Id. (citations omitted).

62 QUATNOO, supra note 41, at 19 ("Zambia under Kaunda before it degenerated into the authoritarian mode, experienced the guided form of democracy. ... Under President Moi . . . Kenya can . . be considered as an example of guided democracy, albeit in its worst form."); Richard L. Sklar, Democracy in Africa, in Political Domination in Africa: Reflections on the Limits of Power 20-21, 23-24 (Patrick Chabal ed., 1986). Under a guided democracy the state is the "[e]xecutor of the general will" of the people, the political process is characterized by the "[u]nchecked pursuit of objectives proclaimed by the ruling elite," and citizens" rights to participation in the electoral process are significantly curtailed by the ruling elite. PINKNEY, supra note 41 , at $8-9$ tbl.1.1; accord $i d$. at 11 . According to Pinkney, a guided democracy may suffer from "[t]yranny of the elite" and "borders on authoritarianism." Id. at 9 tbl.1.1, 11; see also EDOzlE, supra note 59, at 35,72 .

63 See supra note 4 and accompanying text; see also EDOZIE, supra note 59, at 25-26.

64 Touria Prayag, A Strong Democracy Addicted to Musical Chairs, Global: The InT'L Briefing, Third Quarter 2012, at 66, http://global-briefing.org/Global/Global_11/Global_Issue_11/index.html\#/68. 
democracy has proved to be the most economically productive and therefore the most attractive to African countries with shattered economies. ${ }^{, 65}$ In fact, the $\mathrm{AU}$ has sought to address the potential economic inequities in African states by obligating member states that have ratified the ADC to ensure "[e]quitable allocation of the nation's wealth and natural resources." Additionally, under a substantive approach to defining democracy, it is essential that an individual's human rights be protected as part of a liberal democracy. ${ }^{67}$ Jack Donnelly contends that "the struggle for liberal democracy is a struggle for human rights ...."68 The establishment of liberal democracies in African countries may facilitate the protection of human rights and economic development on the African continent.

Given the provisions of the ADC aimed at promoting the establishment of liberal democracies, the term "democracy" as used in this Article, will refer to liberal democracy, which is characterized by a representative form of government. Similarly, the following analysis of the prior instruments adopted by the AU focuses on the inability of those instruments to facilitate liberal democratic ideals in AU member states.

\section{THE AU'S PRIOR EFFORTS TO PROMOTE DEMOCRACY IN AFRICA}

\section{A. African Charter and Constitutive Act}

The African Charter was adopted by member states of the OAU in $1981 .{ }^{69}$ The African Charter contains a number of provisions that specifically address fundamental rights necessary for the promotion of democracy. For example, Article 10 provides that an individual has the right to freedom of association

65 QUAINOO, supra note 41, at 20; see also supra note 43 and accompanying text. Some scholars contend that liberal democracies have been economically successful because "liberal democracy has capitalism as its twin." QUAINOO, supra note 41, at 20.

66 ADC, supra note 1, art. 33(6).

67 PINKNEY, supra note 41, at 16 ("In a substantive order, citizens enjoy individual freedom . . . Equity, justice, civil liberties, and human rights prevail."); Jack Donnelly, Human Rights, Democracy, and Development, 21 Hum. RTS. Q. 608, 622 (1999) ("Liberal democracy is tempered or constrained in particular ways, not simply a more fully developed electoral democracy. It may take longer to establish liberal democracies, but that is because they must meet certain substantive, not merely procedural, standards. Furthermore, they must achieve a difficult balancing of democratic and human rights principles.").

68 Donnelly, supra note 67, at 621; accord id. at 620-21 ("Democracy and human rights are not merely compatible but are mutually reinforcing in contemporary liberal democracies only because of a particular resolution of the competing claims of democracy and human rights that gives priority to human rights.").

69 African Charter on Human and Peoples' Rights, adopted June 27, 1981, 1520 U.N.T.S. 217 (entered into force Oct. 21, 1986) [hereinafter African Charter]. 
provided that he or she abides by the law, while Article 11 provides that every individual has the right to assemble freely with others. ${ }^{70}$ Similarly, Article 9 establishes the right of freedom of expression and Article 13 provides that every individual has the right to participate freely in the government of his or her country either directly or through freely chosen representatives in accordance with the provisions of the law. ${ }^{71}$

While the African Charter is a valuable instrument that seeks to protect human rights in Africa, this instrument alone is incapable of achieving widespread democracy in Africa for a number of reasons. ${ }^{72}$ First, rather than focusing exclusively on the promotion of democracy in Africa, the African Charter is focused on establishing fundamental human rights and duties such as the duty of an individual to his or her family and society. ${ }^{73}$ Second, in contrast to the ADC, the African Charter does not create a detailed mechanism for the facilitation of free and fair elections and good governance. ${ }^{74}$ Third, although the African Charter recognizes certain rights that may aid in the promotion of democracy, the African Charter does not expressly acknowledge other rights that are essential to the formation of democracy. For instance, the African Charter does not expressly state that every individual has the right to vote in free and fair democratic elections. ${ }^{75}$ Further, the African Charter does not recognize the "One person, one vote" principle, ${ }^{76}$ which is arguably instrumental to any liberal democracy. ${ }^{77}$

Fourth, while the African Charter recognizes certain human rights as crucial to the establishment of democratic order, a number of these rights are

70 Id. arts. $10-11$.

71 ld. arts. 9(2), 13(1).

72 In some instances the African Union has obtained member state compliance with the human rights and democratic principles contained in the African Charter. See generally Stacy-Ann Elvy, Theories of State Compliance with International Law: Assessing the African Union's Ability to Ensure State Compliance with the African Charter and Constitutive Act, 41 GA. J. INT'L \& COMP. L. 75, 77-128 (2012) (arguing that the AU is successfully providing incentives for its smaller and less powerful member states, such as Guinea-Conakry, to comply with the Constitutive Act of the African Union and the African Charter, but the AU continues to struggle with obtaining the compliance of larger more powerful states such as Kenya, Libya, and Zimbabwe). Despite this relative success, it is unlikely that widespread democracy will occur based solely on the AU's implementation of the African Charter and the Constitutive Act of the African Union.

73 African Charter, supra note 69, art. 27(1).

74 Compare id., with ADC, supra note 1, arts. 17, 18, 44, 56.

75 See African Charter, supra note 69

76 See id.

77 Cf. Jonathan W. Still, Political Equality and Election Systems, 91 ETHICs 375, 376 (1981) (describing political scientists' characterization of political equality as being essential to democracy). 
subject to claw-back clauses. ${ }^{78}$ For example, Article 9 provides that every individual shall have the right to express and disseminate his opinions within the law. ${ }^{79}$ In theory, the right of freedom of expression may be limited by laws enacted by a member state. For example, Article 178 of the Libyan Penal Code, as reported on by Human Rights Watch, provided that individuals who undermine the international reputation of Libya can be sentenced to life in prison. ${ }^{80}$ Prior to Muammar al-Gaddafi's death, the Human Rights Watch World Report for 2011 indicated that Gaddafi had imposed serious restrictions on freedom of expression and freedom of assembly and that Libyans who criticized Gaddafi routinely faced prosecution. ${ }^{81}$ Libyan dissident Jamal al-Haji served four months in prison after he was arrested for complaining about the torture and inhumane conditions that he experienced during his years as a political prisoner. ${ }^{82}$

During the 1990s, the OAU failed to guarantee peace and security on the African continent and many analysts began to question whether the OAU was a suitable organization to address the circumstances faced by Africa at that time. ${ }^{83}$ As a result, the member states of the OAU replaced the OAU with the $\mathrm{AU}$ through the adoption of the Constitutive Act, which entered into force on May 26, 2001. ${ }^{84}$

There are a number of provisions in the Constitutive Act that address the promotion of democracy. For example, Article $3(\mathrm{~g})$ obligates the $\mathrm{AU}$ to "[p]romote democratic principles and institutions, popular participation and

78 See Christof Heyns, The African Regional Human Rights System: The African Charter, 108 PENN ST. L. REV. 679, 687-88 (2004) ("Claw-back clauses seem to recognize the right in question [for individuals] only to the extent that such a right is not infringed upon by national law."). It should be noted that the AU Human Rights Commission has stated that the claw-back clauses must be interpreted in a manner that is consistent with international law and the protection of human rights. $l d$. at 688-89. However, the continued existence of the claw-back clauses in the African Charter signals to African states that the AU may not be serious about protecting human rights See generally Elvy, supra note 72, at 94-99 (discussing claw-back clauses in the African Charter). Additionally, although the AU Human Rights Commission has held that it will liberally construe the claw-back clauses, the decisions of the AU Human Rights Commission are generally non-binding. See id: Heynes, supra at 688-89.

79 African Charter, supra note 69 , art. 9.

80 See HUMAN RIGHTS WATCH, WORLD REPORT 2011, at 564 (2011), available at http:/www.hrw.org/ sites/default/files/reports/wr2011.pdf.

$81 \mathrm{Id}$. at $564-65$.

82 Id. at 564 .

83 See Corinne A.A. Packer \& Donald Rukare, The New African Union and Its Constitutive Act, 96 AM. J. INT'L L. 365, 367 (2002).

84 Constitutive Act of the African Union pmbl., done July 11,2000, 2158 U.N.T.S. 3 (entered into force May 26, 2001) [hereinafter Constitutive Act]. 
good governance. ${ }^{955}$ The Constitutive Act also sets forth a list of fundamental principles in Article 4, including "[r]espect for democratic principles, human rights, the rule of law and good governance," the "condemnation and rejection of impunity and political assassination...," and the "[c]ondemnation and rejection of unconstitutional changes of governments. ${ }^{, 86}$ Article 4(j) gives AU member states the ability to request an AU intervention "in order to restore peace and security," which means that a recognized government can request intervention in its own state in the event of an unconstitutional change of government. $^{87}$

While the Constitutive Act expressly affirms the AU's commitment to democracy in Africa and condemns unconstitutional changes of government, the Constitutive Act contains only general terms reaffirming and encouraging democracy in African states. ${ }^{88}$ Like the African Charter, the Constitutive Act does not specifically provide for a mechanism through which the $\mathrm{AU}$ will promote free and fair elections and good democratic governance in African countries. ${ }^{89}$ The AU's failure to include such a mechanism in the Constitutive Act may have contributed to the current dearth of liberal democracies in Africa. Perhaps AU member states failed to include such a mechanism because the main purpose of the Constitutive Act was not to specifically promote democracy, but to establish a new organization, the AU, which would succeed where the OAU had failed. ${ }^{90}$ However, despite the purpose behind the adoption of the Constitutive Act, it is surprising that the AU did not ensure that the Constitutive Act adequately addressed the issue of promoting democracy in Africa because Africa has always struggled with the lack of democracy.

The Constitutive Act also provides for the imposition of sanctions against a member state whose government has usurped power through unconstitutional means. Article 30 explains that "[g]overnments which shall come to power through unconstitutional means shall not be allowed to participate in the activities of the Union." ${ }^{91}$ Lastly, Article 4(h) of the Constitutive Act confers on the AU the right to intervene, even by military means, in a member state "in respect of grave circumstances, namely war crimes, genocide and crimes

85 Constitutive Act, supra note 84 , art. 3(g); Packer \& Rukare, supra note 83 , at 371 .

86 Constitutive Act, supra note 84, art. 4(m), (o) (p).

87 Id. art. 4(j)

88 See id. pmbl, art. $4(\mathrm{~m})$

89 See Constitutive Act, supra note 84; African Charter, supra note 69.

90 See Constitutive Act, supra note 84 , pmbl. The majority of the Constitutive Act is concerned with establishing the organs of the $\mathrm{AU}$ and defining their function. See id. arts. 5-22.

91 ld. art. 30 . 
against humanity." $" 92$ In theory, this provision enables the AU to take military action to address unconstitutional changes of government that involve war crimes, crimes against humanity, or genocide, and restore constitutional order within a state. The terms "unconstitutional means" and "unconstitutional changes of governments" are not defined in the Constitutive Act. ${ }^{93}$ However, Article 7(1)(g) of the Protocol Relating to the Establishment of the Peace and Security Council of the African Union ("AU PSC Protocol") grants the Peace and Security Council ("PSC") the power to "institute sanctions whenever an unconstitutional change of Government takes place in a Member State, as provided for in the Lomé Declaration." "T4 The provisions of the Lomé Declaration, discussed below, define an unconstitutional change of government.

\section{B. Lomé Declaration}

The formation and endurance of democracy is essential to avoid repeated episodes of armed conflicts and human rights violations. The charter establishing the OAU did not contain a specific reference to the promotion of democracy in Africa. Many of the provisions of the OAU Charter focused on the elimination of colonialism in Africa and non-interference in the internal affairs of individual African countries. ${ }^{95}$ During the Cold War, the noninterference clause was used by African heads of state to prevent the OAU and other international organizations from holding African leaders responsible for human rights abuses, including suppressing free and democratic elections. For example, the OAU was unable to intervene in Uganda during ldi Amin's eightyear rule, which led to the massacre of over 300,000 Ugandans. ${ }^{96}$

The OAU expressed its opposition to unconstitutional changes of government in May 1997 ("Harare Decision") by condemning the coup d'état that occurred in Sierra Leone and encouraging its member states and the international community "to refrain from recognizing the new regime ...."97 Then, two years later in Algiers ("Algiers Decision"), the OAU signaled its

92 Id. art. 4(h).

93 See id.

94 Protocol Relating to the Establishment of the Peace and Security Council of the African Union art. $7(1)(g)$, adopted July 9, 2002, http:/www.au.int/en/sites/default/files/Protocol_peace_and_security.pdf [hereinafter AU PSC Protocol].

95 OAU Charter arts. II-III, http//www.au.int/en/sites/default/files/OAU Charter 1963.pdf.

96 Olusola Ojo \& Amadu Sesay, The O.A.U. and Human Rights: Prospects for the 1980s and Beyond, 8 Hum. RTS. Q. 89,91, 93 (1986).

97 OAU C.M. Dec. 357 (LXVI), paras. (a)-(b), O.A.U. Doc. CM/2004 (LXVI)-C (May 28-31, 1997). 
continued opposition to unconstitutional changes of government by referencing the principles of the Universal Declaration of Democracy, ${ }^{98}$ and by calling for the restoration of constitutional order in all African countries that had been subject to a military coup since the Harare Decision. ${ }^{99}$ While the Harare Decision and the Algiers Decision constituted a step in the right direction for the OAU in terms of promoting democracy, the Harare Decision and the Algiers Decision ${ }^{100}$ did not establish a general policy that the OAU would follow in the event of an unconstitutional change of government in any African country, as both decisions were established in response to unconstitutional changes of government that occurred in specific countries. ${ }^{101}$ Furthermore, neither decision established an enforcement mechanism that could be utilized against the perpetrators of unconstitutional changes of government.

In a further effort to promote democracy in Africa, the OAU adopted the Declaration on the Framework for an OAU Response to Unconstitutional Changes in Government ("Lomé Declaration") in July 2000. ${ }^{102}$ Taken together, the Harare Decision, the Algiers Decision, and the Lomé Declaration established an official framework for the OAU's response to unconstitutional changes of government in Africa. By adopting the Lomé Declaration, the OAU recognized that rather than relying on past decisions made by the OAU's Assembly or Council of Ministers in response to unconstitutional changes of government in specific countries, the OAU needed to provide a solid framework and a general policy that would clearly articulate the principles of democratic governance to which each member state must adhere. ${ }^{103}$ The OAU specifically addressed the impact of coup d'états on democracy in Africa in the Lomé Declaration. ${ }^{104}$ The OAU's recognition and condemnation of coup d'états in the Lomé Declaration was significant because of the prevalence of such coups in Africa at that time. ${ }^{105}$ However, condemning coup d'états is but

\footnotetext{
98 OAU A.H.G. Dec. 141 (XXXV), paras. 3-5, O.A.U. Doc. AHG/Dec. 141 (XXXV) (July 12-14, 1999).

99 OAU A.H.G. Dec. 142 (XXXV), para. 1, O.A.U. Doc. AHG/Dec.142 (XXXV) (July 12-14, 1999).

100 The Algiers Decision was adopted in response to military coups that occurred in Comoros, Congo Brazzaville, Guinea Bissau, and Niger. Eki Yemisi Omorogbe, A Club of Incumbents? The African Union and Coups d'État, 44 VAnd. J. Transnat'L L. 123, 127 (2011).

101 See supra notes $97-100$ and accompanying text.

102 Declaration on the Framework for an OAU Response to Unconstitutional Changes of Government, OAU A.H.G. Decl. 5 (XXXVI), O.A.U. Doc. AHG/Decl.5 (XXXVI) (July 10-12, 2000) [hereinafter Lomé Declaration].

103 Id.

104 Id.

105 Paul D. Williams, The African Union's Emerging Security Culture: Options for U.S. Policymakers, Center For StRATEGIC \& INT'L STUd. (July 13, 2007), http://csis.org/publication/african-unions-emergingsecurity-culture-options-us-policymakers; see also Omorogbe, supra note 100, at 128.
} 
the first step toward the promotion of the democracy. In fact, condemning a coup d'état does not necessarily promote democracy if the government that was overthrown and that seeks to be reinstated came to power through undemocratic means.

As part of the OAU's response to coup d'états and other unconstitutional changes of government, the OAU first had to determine what governmental or political actions would constitute an unconstitutional change of government, which was ultimately defined in the Lomé Declaration to include the following:
i). military coup d'etat against a democratically elected Government;
ii). intervention by mercenaries to replace a democratically elected Government;
iii). replacement of democratically elected Governments by armed dissident groups and rebel movements;
iv). the refusal by an incumbent Government to relinquish power to the winning party after free, fair and regular
elections.

Unfortunately, the Lomé Declaration was not successful in aiding the OAU in its efforts to promote democracy in African countries. In 2006, a ministerial meeting of the $A U$ reviewed the Lomé Declaration and its effectiveness. ${ }^{107}$ The AU Commissioner for Political Affairs, Julia D. Joiner, explained that the Lomé Declaration had not prevented unconstitutional changes in Africa, and that it must be reviewed with a goal toward addressing the problem of unconstitutional changes of government in African countries. ${ }^{108}$ The Lomé Declaration was ineffective for a number of reasons. First, unlike the ADC, the Lomé Declaration was a non-binding resolution of the $\mathrm{OAU}$, and therefore, member states of the OAU were not legally obligated to adhere to the principles espoused in the Lomé Declaration. ${ }^{109}$ Second, in contrast to the

\footnotetext{
106 Lomé Declaration, supra note 102.

107 Press Release, African Union, African Charter on Democracy, Elections and Governance, The Focus of a Meeting of Experts at the Headquarters of the AUC in Addis Ababa, A.U. Press Release 12/2006 (Mar. 31, 2006) [hereinafter Press Release on the ADC].

108 Ministers Discuss Draft Charter on Governance in Africa, PANAPRESS (Apr. 6, 2006), http://www. panapress.com/Ministers-discuss-draft-Charter-on-governance-in-Africa-13-580653-18-lang2-index.html; see also African Union, Draft Charter on Democracy, Elections and Governance: Explanatory Note, http:/ www.africa-union.org/root/au/conferences/past/2006/april/pa/apr7/meeting.htm (last visited Mar. 20, 2013).

109 See A.U. Assemb., Rules of Procedure of the Assembly of the Union, r. 33(1)(c) (July 9-10, 2002) [hereinafter AU Assembly Rules of Procedure], available at http://www.africa-union.org/rule prot/rules
} 
ADC, the Lomé Declaration failed to set out a road map for the promotion of democracy in countries that were ruled by long-serving dictators. ${ }^{110}$ Third, the definition of an unconstitutional change of government in the Lomé Declaration hinged on mercenaries, rebels, armed groups, or the military being used to remove a democratically elected government. ${ }^{111}$ Therefore, if a military coup d'état occurred in an African country to remove an undemocratically elected government the coup d'état would not technically qualify as an "unconstitutional change" under the Lomé Declaration. ${ }^{12}$ While removing an undemocratic government through any means necessary sounds great in theory, it does not necessarily facilitate the promotion of democracy. The leaders of a military coup d'état who removed an undemocratic government would have achieved control of the government through undemocratic means, and in many instances were likely to insist on retaining power, like their predecessors, by continuing to utilize similar undemocratic means. The OAU failed to address this problem in the Lomé Declaration.

Moreover, the enforcement mechanism and procedures described in the Lomé Declaration were woefully inadequate. For example, the Lomé Declaration established a six-month period after the suspension of the country from OAU activities for the imposition of targeted sanctions. ${ }^{13}$ Timely imposing targeted sanctions has been recognized as a tool that can be used to deter non-compliance. ${ }^{114}$ Why wait six months to impose sanctions if it is evident in the fourth month that the rebels, military, or armed groups do not intend to restore constitutional order or are facilitating the mass killing of civilians? Additionally, during this six-month period, the Lomé Declaration provided that the OAU was to use "discreet moral pressure" on the perpetrators of the unconstitutional change of government to engender cooperation with the

\footnotetext{
Assembly.pdf (indicating that declarations of the Assembly are non-binding). Compare ADC, supra note 1, arts. 47-49, with Lomé Declaration, supra note 102.

110 Compare ADC, supra note 1, arts. 12, 17, 44, with Lomé Declaration, supra note 102.

111 See AU Assembly Rules of Procedure, supra note 109, r. 37(2)-(3); Lomé Declaration, supra note 102.

112 See Lomé Declaration, supra note 102 (agreeing that a "military coup d'etat against a democratically elected Government" constituted an unconstitutional change of government) (emphasis added).

113 The Lomé Declaration provides "[a]t the expiration of the six months suspension period, a range of limited and targeted sanctions against the regime that stubbornly refuses to restore constitutional order should be instituted, in addition to the suspension from participation in the OAU Policy Organs." Lome Declaration, supra note 102

114 See generally Nikolay Marinov, Do Economic Sanctions Destabilize Country Leaders?, 49 AM. J. POL. SCI. 564, 564 (2005) (concluding that targeted economic sanctions would likely be able to coerce and destabilize foreign leaders)
} 
OAU and to facilitate the restoration of constitutional order. ${ }^{115}$ The term "discreet moral pressure" was not specifically defined in the Lomé Declaration $^{116}$ and it is highly unlikely that armed rebels and mercenaries would respond better to "discreet moral pressure" than targeted sanctions. The failure of the Lomé Declaration evidences that inadequate drafting, the lack of an effective enforcement mechanism, and ineffective utilization impedes the ability of a regional instrument to facilitate democratization.

\section{Elections Declaration}

The Elections Declaration was adopted by member states of the OAU in 2002. ${ }^{117}$ The goal of the Elections Declaration was to establish standards for monitoring free and fair elections in African countries, thereby facilitating the establishment of democracy and democratic institutions across Africa. ${ }^{118}$ The Elections Declaration, like the Lomé Declaration, is a non-binding declaration of the OAU, meaning that member states of the OAU were not legally bound by the provisions of the Elections Declaration. ${ }^{119}$ However, the Elections Declaration is particularly important because it evidences the OAU's intent to foster democracy in Africa. With the Elections Declaration, the OAU recognized the importance of democratic elections as the basis for the authority of all governments and established principles for holding democratic elections. ${ }^{120}$

The Elections Declaration required member states, among other things, to take all steps necessary to ensure implementation of the democratic principles

\footnotetext{
115 Lomé Declaration, supra note 102.

116 See id.

117 OAU/AU Declaration on the Principles Governing Democratic Elections in Africa, OAU A.H.G. Decl. 1 (XXXVIII), O.A.U. Doc. AHG/Decl. 1 (XXXVIII) (July 8, 2002) [hereinafter Elections Declaration].

118 Id. arts. I, II (2), (4).

119 Jakkie Cilliers, Peace, Security and Democracy in Africa?: A Summary of Outcomes from the 2002 OAU/AU Summits in Durban, INST. FOR SECURITY STUD. 13 (Aug. 2002), http:/www. issafrica.org/uploads/ PAPER60.2.PDF; see also AU Assembly Rules of Procedure, supra note 109, r. 33(1)(c).

120 According to the Elections Declaration, democratic elections were to be conducted:
}
a) freely and fairly;
b) under democratic constitutions and in compliance with supportive legal instruments;
c) under a system of separation of powers that ensures in particular, the independence of the judiciary;
d) at regular intervals, as provided for in National Constitutions;
e) by impartial, all-inclusive competent accountable electoral institutions staffed by well-trained personnel and equipped with adequate logistics 
established by the Elections Declaration, including, but not limited to, guaranteeing the civil liberties of all citizens such as "freedom of movement, assembly, association, expression, and campaigning as well as access to the media...."121 The Elections Declaration also reaffirmed a number of the democratic rights recognized by the African Charter. For instance, the Elections Declaration provides that "[e]very citizen shall have the right to participate freely in the government of his or her country, either directly or through freely elected representatives in accordance with the provisions of the law." 22 However, in comparison to the African Charter, which does not specifically recognize an individual's right to vote, ${ }^{123}$ the Elections Declaration recognizes this right and provides that "[e]very citizen has the right to fully participate in the electoral processes of the country, including the right to vote or be voted for, according to the laws of the country and as guaranteed by the [c]onstitution [of the applicable country], without any kind of discrimination." 24 Similarly, the ADC recognizes universal suffrage as an inalienable right. ${ }^{125}$

While the Elections Declaration is more expansive because it specifically recognizes the right to vote, the Elections Declaration contains a claw-back clause similar to the clauses found in the African Charter. The Elections Declaration makes the right to vote subject to the laws of the applicable country. ${ }^{126}$ Similarly, the African Charter provides that a citizen's right to participate freely in his or her government must be exercised "in accordance with the provisions of the law." 127 As previously noted, claw-back clauses can be used by abusive governments to limit the rights recognized by the African Charter and the Elections Declaration. ${ }^{128}$ The ADC does not contain similar claw-back provisions. ${ }^{129}$

\footnotetext{
121 Id. art. III(d); accord id. art. III.

122 Id. art. IV(1)

123 African Charter, supra note 69, art. 13(1). Article 13(1) of the African Charter provides that "[e]very citizen shall have the right to participate freely in the government of his country, either directly or through freely chosen representatives in accordance with the provisions of the law." Id.

124 Elections Declaration, supra note 117 , art IV(2).

125 ADC, supra note 1 , art. 4(2)

126 Elections Declaration, supra note 117, art. IV(2). While the Elections Declaration contemplated the monitoring of elections by the OAU, the Elections Declaration failed to include provisions that specifically addressed the consequences that would be faced by countries that failed to implement the democratic principles contained in the Elections Declaration. Elections Declaration, supra note 117, art. V.

127 African Charter, supra note 69, art. 13(1).

128 Supra note 78.

129 See ADC, supra note 1
} 
The Elections Declaration called for the establishment of a unit that would be responsible for the implementation of the democratic principles contained in the Elections Declaration. ${ }^{130}$ The Executive Council of the AU established the Democracy and Electoral Assistance Unit ("DEAU") in 2006. ${ }^{131}$ The DEAU is responsible for coordinating and implementing the AU's goal of promoting democracy via democratic elections in Africa, including observing and monitoring elections and providing electoral assistance. ${ }^{132}$ The DEAU has struggled with understaffing and the AU scaled back the status of the DEAU from what was initially recommended by an AU feasibility study. ${ }^{133}$ In 2009 and 2010, the DEAU monitored elections in Ethiopia, Sudan, Sao Tome, Burundi, Guinea, Togo, Gabon, Guinea-Bissau, Mauritania, Republic of Congo, Malawi, South Africa, and Algeria. ${ }^{134}$

In 2010, the DEAU observed elections in Ethiopia and concluded that the Ethiopian elections generally complied with the democratic principles set forth in the Elections Declaration. ${ }^{135}$ The DEAU also observed elections in Sudan in 2010 and observed that there was a need to ensure a level playing field for all political parties and candidates in elections. ${ }^{136}$

Despite the DEAU's observation of elections in a number of African countries, the effectiveness and utility of the DEAU is debateable given the fact that some of the elections observed by the DEAU have led to the election of heads of state under questionable circumstances. This lack of efficacy may have been due to the AU's under-use of the DEAU. The 2010 Sudan election

\footnotetext{
130 See Elections Declaration, supra note 117, art. VI(d) ("[A] Democratization and Election Monitoring Unit ... will also discharge issues on good governance.").

131 Decision on the Establishment and Organization of a Democracy and Electoral Assistance Unit and Fund, AU E.C. Dec. 300 (IX), A.U. Doc. EX.CL/272 (IX) (June 25-29, 2006).

132 Id. para 3(ii).

133 Carl W. Dundas, THE LAG OF THE 21 ST Century Democratic Elections: IN THE AFriCAN Union Member States 382-83 (2011); Jana Widdifield, Helping Africa, DU TODAY (Sept. 2008), http://blogs.du. edu/today/magazine/helping-africa. In 2010, the DEAU and the Pan-African Parliament elected to merge their election-monitoring efforts. DUNDAS, supra, at 383 n.187.

134 See Election Declarations 2009-2010, AFr. UNION ELECTIONS ASSISTANCE UNT, http:/www africaunion.org/root/AU/AUC/Departments/PA/ELECTION_UNIT/AU_Election_Unit_Declarations.htm (last visited Aug. 13, 2012).

135 Preliminary Statement of the AU Observer Mission on the Ethiopia Legislative Elections of 23 May 2010, (May 26, 2010), http://Www.africa-union.org/root/AU/AUC/Departments/PA/ELECTION_UNIT/AU_ Election_Unit_Declarations.htm (follow the "PRELIMINARY STATEMENT OF THE AFRICAN UNION OBSERVER MISSION ON THE ETHIOPIA LEGISLATIVE ELECTONS OF 23 May, 2010" hyperlink).

136 Preliminary Statement of the AU Observer Mission to the Sudan Elections 11-15 April 2010, (Apr. 18, 2010), http://www.africa-union.org/root/AU/AUC/Departments/PA/ELECTION_UNIT/AU_Election_Unit_ Declarations.htm (follow the "EN" hyperlink next to "PRELIMINARY STATEMENT OF THE AFRICAN UNION OBSERVER MISSION TO THE SUDAN ELECTIONS, 11 - 15 APRIL 2010”).
} 
led to the election of Omar al-Bashir, ${ }^{137}$ who has been indicted by the International Criminal Court ("ICC") for war crimes committed in Darfur, and the AU continues to oppose the ICC's prosecution of al-Bashir. ${ }^{138}$ Similarly, in the 2010 elections in Burundi, which were observed by the DEAU, incumbent President Pierre Nkurunziza was the only presidential candidate on the ballot. ${ }^{139}$ President Nkurunziza came to power in Burundi in $2005 .^{140}$ In connection with the 2010 Ethiopian elections, the Ethiopian government enacted anti-terrorism laws that gave broad powers to law enforcement officers and established harsh criminal penalties that could be applied to suppress the

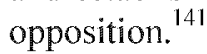

The adoption of the Elections Declaration and the establishment of the DEAU underscored the AU's commitment and attempts to promote democracy through free and fair elections. However, the impact, if any, that the DEAU has had on the promotion of free and fair elections in African countries, is unclear, in light of its under-use. Additionally, the Elections Declaration simply established general principles for the establishment of free and fair elections, but failed to create an enforcement mechanism. ${ }^{142}$ The failure of the Elections Declaration to achieve widespread democracy in Africa illustrates that democracy cannot be achieved simply by the adoption of a new regional instrument.

\section{Corruption Convention}

Transparency and accountability in public administration is central to the establishment of liberal democracies. ${ }^{143}$ Dr. Edward Hoseah, a board member on the AU Advisory Board on Corruption, acknowledged that "[o]n [a] yearly basis Africa loses more than [\$]148 billion due to the practice [of corruption],

\footnotetext{
137 Jeffrey Gettleman, Sudan's President Wins Election as Couniry Nears Vote To Split, N.Y. TIMES, Apr. 27,2010 , at $\mathrm{A} 12$

138 Ethiopia To Host African Union Summit After Omar al-Bashir Malawi Row, BBC News (June 12, 2012), http://www.bbc.co uk/news/world-africa-18407396.

139 See Burundi Elections, BBC World SERviCE (June 28, 2010, 3:52 PM), http://www.bbc.co.uk/ worldservice/africa/2010/06/100628_burundielexnew.shtml; see also Election Declarations 2009-2010, see supra note 134.

140 Burundi, CIA - WORLD FACTBOOK, https://www.cia.gov/library/publications/the-world-factbook/geos/ by.html (last updated Mar. 26, 2013); Elections in Burundi, AFR. ELECTIONS DATABASE, http:// africanelections.tripod.com/bi.html (last updated May 8, 2011).

141 HuMAN RIgHTS WATch, WORLD REPORT 2010, at 119 (2010), available at http:/www.hrw.org/ sites/default/files/reports/wr2010.pdf.

142 See supra Part II.C.

143 See G.A. Res. 59/201, supra note 52.
} 
and perpetuators of corruption are taking... money from the continent to banks based in the developed world."144 Recognizing that corruption is rampant in African governments and that corruption seriously hinders the establishment of democratic institutions and economic development in African countries, member states of the AU adopted the Corruption Convention, ${ }^{145}$ which entered into force on August 5, 2006. ${ }^{146}$ Unlike the Lomé Declaration and Elections Declaration, which are non-binding instruments, the Corruption Convention is binding on member states that have ratified it. ${ }^{147}$

The Corruption Convention establishes a number of principles aimed at combating corruption and promoting democracy in Africa. The Corruption Convention provides that state parties must: condemn and reject acts of corruption; respect human rights, as well as democratic principles and institutions; and ensure socio-economic development by promoting social justice. $^{148}$

The Corruption Convention establishes the Advisory Board on Corruption ("ABC"), which is responsible for the promotion of the anti-corruption

144 Lusekelo Philemon, Graft Cosiing Africa Dearly, IPPMEDIA (June 19, 2012), http:/www. ippmedia.com/frontend/index.php?1=42768 (quoting Dr. Edward Hoseah) (internal quotation marks omitted).

145 African Union Convention on Preventing and Combating Corruption, adopted July 11, 2003, http:/www.au.int/en/sites/default/files/AFRICAN_UNION_CONVENTION_PREVENTING_COMBATING _CORRUPTION.pdf [hereinafter Corruption Convention]; see also AU Assemb. Dec. 27 (II), para. 2, A.U. Doc. Assembly/AU/Dec.27 (II) (July 10-12, 2003).

146 African Union, List of Countries Which Have Signed, Ratified/Acceded to the African Convention on Preventing and Combating Corruption, http:/Www.africa-union.org/root/au/Documents/Treaties/List/African $\% 20$ Convention $\% 20$ on $\% 20$ Combating\%20Corruption.pdf (last updated Mar. 1, 2013) [hereinafter Ratification Status of the Corruption Convention]

147 Corruption Convention, supra note 145, art. 23(3); supra text accompanying notes 109, 119.

148 Corruption Convention, supra note 145 , art. 3. Member states of the OAS have adopted the InterAmerican Convention Against Corruption ("OAS Anti-Corruption Convention"). Inter-American Convention Against Corruption, opened for signature Mar. 29, 1996, S. TREATY DOC. No. 105-39 (1998) [hereinafter OAS Anti-Corruption Convention]. The OAS Anti-Corruption Convention obligates ratifying states to take steps to eliminate corruption in their respective countries. OAS Anti-Corruption Convention, supra, arts. XXII, XXV. Certain acts of corruption are similarly defined in both the OAS Anti-Corruption Convention and the AU Corruption Convention. Compare Corruption Convention, supra note 145, art. 4(1)(a)-(c), with OAS AntiCorruption Convention, supra, art. VI(1)(a)-(c). However, when compared to the OAS Anti-Corruption Convention, the AU Corruption Convention more broadly defines acts of corruption. For example, the AU Corruption Convention defines corruption not only as acts of corruption committed by public officials, but also as acts committed by anyone claiming to "exert any improper influence over the decision making of any person performing functions in the public or private sector ...," even if the alleged influence does not lead to the intended result. Corruption Convention, supra note 145, art. 4(1)(a), (f). The OAS Anti-Corruption Convention does not contain a similar definition of acts of corruption. OAS Anti-Corruption Convention, supra, arts. VI(1), XI(1) 
principles contained in the Convention. ${ }^{149}$ The advisory board is also responsible for submitting reports to the $\mathrm{AU}$ on the status of each member state's compliance with the Corruption Convention. ${ }^{150}$ There was a three-year gap between the date that the Corruption Convention entered into force and the date that the first advisory board was created. The first advisory board on corruption was established in $2009,{ }^{151}$ and as previously noted, the Corruption Convention entered into force on August 5, 2006. ${ }^{152}$ A new advisory board was elected on January 31, 2011 for a period of two years in accordance with the Corruption Convention. ${ }^{153}$ The ability of the ABC to fulfill its mandate to eradicate corruption has been hindered by a lack of financial and material resources ${ }^{154}$ and the short two-year term that is given to elected board members. ${ }^{155}$ In its 2011-2015 Strategic Plan, the ABC acknowledged that the "two-year term of office for Board members is too short to ensure continuity on shared vision in the achievement of the Board's mandate." of March 1, 2013, only thirty-four of the fifty-four member states of the AU have actually ratified the Corruption Convention. ${ }^{157}$ The ABC's mandate and reach, therefore, extends only to the thirty-four countries that have ratified the Corruption Convention, which poses a significant obstacle in combatting corruption in all African countries. The lack of state ratifications, lack of financial resources, and the short two-year term for board members, evidence that inadequately drafted legal instruments and inadequate utilization of regional instruments may impede efforts to promote democracy.

The Corruption Convention is notable for its imposition of a state-reporting requirement. ${ }^{158}$ However, this state-reporting requirement suffers from the

149 Corruption Convention, supra note 145 , art. 22(1), (5)(a), (d).

150 Id. art. 22(5)(h).

151 AU Advisory Board of Corruption, 2011-2015 Strategic Plan 7, 23 (June 2011), http:/au.int/SP/ ANTICOR/resources/documents/2011-2015-strategic-plan (follow the hyperlink "AU ABC Strategic Plan 2011-2015 (EN) ${ }^{37}$ ) [hereinafter Strategic Plan].

152 See supra text accompanying note 146

153 Corruption Convention, supra note 145, art. 22(4); Strategic Plan, supra note 151, at 7.

154 Strategic Plan, supra note 151, at 20.

155 See id. at $20-21$

$156 \mathrm{Id}$. at 21

157 Ratification Status Corruption Convention, supra note 146. The OAS has been more successful at obtaining a higher ratio of member state ratifications. As of 2012, thirty-three of the thirty-five member states of the OAS have ratified the OAS Anti-Corruption Convention. Organization of American States, Signatories and Ratifications: B-58: Inter-American Convention Against Corruption, http:/www.oas.org/juridico/english/ Sigs/b-58.html (last visited Mar. 20, 2013).

158 Corruption Convention, supra note 145, art. 22(7). While Article X of the OAS Anti-Corruption Convention requires state parties to notify the OAS once the state has enacted legislation to comply with the requirements of the convention, the OAS Anti-Corruption Convention does not specifically require state 
same problem as the state reporting requirements set forth in the African Charter. The Corruption Convention provides that after the initial report, which is to be submitted by state parties within one year of the Corruption Convention entering into force, each state party must report to the $\mathrm{ABC}$ on the status of their compliance with the convention at least once a year. ${ }^{159}$ Similarly, the African Charter provides that each member state must submit to the AU every two years a report on the measures taken by the state to ensure compliance with the principles set forth in the African Charter. ${ }^{160}$ However, neither the Corruption Convention nor the African Charter specifically addresses the consequences that will be faced by state parties that fail to satisfy these reporting requirements. Such consequences could include the issuance of economic and political sanctions against non-compliant member states or the suspension of participation in the AU until the reports have been submitted.

Technically the AU Human Rights Commission and the $\mathrm{ABC}$ have the power to report state non-compliance to the Assembly ${ }^{161}$ or the Executive Council. ${ }^{162}$ The Assembly then has the ability to decide whether to sanction a state for failure to act in compliance with the decision and policies of the AU pursuant to the terms of the Constitutive Act. ${ }^{163}$ However, despite the Assembly's powers under the Constitutive Act, the inability of the AU to obtain member state compliance with the state reporting procedures under the

parties to submit annual reports to the OAS on the status of compliance with the principles of the convention. OAS Anti-Corruption Convention, supra note 148, art. X. It should be noted that on June 4, 2001, the OAS General Assembly adopted The Mechanism for Follow-Up on the Implementation of the Inter-American Convention against Corruption ("MESICIC"), which established an inter-governmental body that is responsible for helping state parties in their efforts to implement the OAS Corruption Convention. OAS A.G. Res. 1784 (XXXI-O/01), O.A.S. Doc. AG/RES. 1784 (XXXI-O/01) (June 5, 2001). The MESICIC also reviews reports and answers questionnaires submitted by State Parties addressing the compliance status of such states with the OAS Corruption Convention. OAS A.G. Res. 1784 (XXXI-O/01), supra, app. I, para. 7(b); see also OAS Dep't of Legal Cooperation, Frequently Asked Questions, http://www.oas.org/juridico/ english/faq_ac.htm (last visited Mar. 20, 2013).

159 Corruption Convention, supra note 145, art. 22(7).

160 African Charter, supra note 69 , art. 62.

161 Afr. Comm'n on Human \& People's Rights [ACHPR], Rules of Procedure of the African Commission on Human and Peoples' Rights of 2010, rr. 76-78 (Aug. 18, 2010), http:/www.achpr.org/files/instruments/ rules-of-procedure-2010/rules_of_procedure_2010_en.pdf. The AU Human Rights Commission does not have the power to render binding decisions. See African Charter, supra note 69 , arts. $47,52,58$. The AU Human Rights Commission acknowledges that "[t]he mandate of the Commission is quasi-judicial and as such, its final recommendations are not in themselves legally binding on the States concerned." ACHPR, Communications Procedure, http://www.achpr.org/communications/procedure (last visited Aug. 14, 2012). However, the Assembly retains the power to act on decisions of the AU Human Rights Commission. See African Charter, supra note 69, arts. 52-54, 58-59.

162 Corruption Convention, supra note 145, art. 22(h)

163 Constitutive Act, supra note 84, art. 23(2). 
African Charter has been well documented. ${ }^{164}$ For example, according to the AU Human Rights Commission's website, as of March 2013, there are twelve member states who have never submitted state reports and only six of the fiftyfour member states are up to date on all of their reports. ${ }^{165}$ If the AU continues to adopt a similar position in its implementation of the state reporting requirements under the Corruption Convention, member states will have no incentive to comply with these reporting requirements, and the AU will likely face the same state reporting problems that it currently faces under the African Charter. The ability of the AU to combat corruption and promote democracy is, at least in part, dependent on the AU's ability to obtain information on the extent of corruption in African countries. These state reporting problems illustrate that effective use and enforcement of regional instruments is necessary to engender state compliance and combat latent problems that prevent the establishment of viable democracies.

Despite widespread corruption in Africa, there are a few countries in Africa that appear to be winning the fight against corruption. In 2010, Botswana, Cape Verde, Rwanda, and Mauritius were ranked by the World Bank among the least corrupt African countries. ${ }^{166}$ These countries should serve as a reminder to other African countries that it is possible to successfully combat corruption. The success of these four countries in combating corruption appears to be due to the adoption of strong internal anti-corruption measures ${ }^{167}$

164 Takele Soboka Bulto, Beyond the Promises: Resuscitating the State Reporting Procedure Under the African Charter on Human and Peoples' Rights, 12 BUFF. HuM. RTS. L. REV. 57, 69-72 (2006). For a detailed discussion of the state reporting requirements under the African Charter, see $i d$. at $69-91$.

165 ACHPR, State Reports and Concluding Observations, http:/www achpr.org/states/reports-andconcluding-observations (last visited Aug. 13, 2012) [hereinafter State Reports and Concluding Observations].

166 World Map: Control of Comuption (2010), WORLDWIDE GOVERNANCE INDICATORS, http//info worldbank.org/governance/wgi/worldmap_start.asp?allcountries=1 (select "Control of Corruption" in the dropdown menu under "1 Select Indicator"; then select the "2010" radio button under "2 Select Year"; then select the button "Submit Choices") (last visited Mar. 20, 2013). Rwanda had a percentile rank of 70.8 , Mauritius had a percentile rank of 73.2, while Cape Verde had a percentile rank of 74.6, and Botswana, which is the least corrupt African country, had a percentile rank of 80.4. Statistical Table: Control of Corruption, Comparison Across Several Countries, Worldwide Governance IndiCATors, http://info.worldbank.org/ governance/wgi/mc_countries asp (select "Control of Corruption" in the dropdown menu under "I Select Indicator"; then select "Sub-Saharan Africa" radio button under "2 Select Region"; then select the boxes labeled "Rwanda," "Mauritius," "Cape Verde," and "Botswana"; then select button labeled "Submit Choices"; then select "Year" in the dropdown menu under "2 Select Comparator"; then select "2010" under "3 Select Year"; then select "Table" icon) (last visited Mar. 20, 2013); see also THE WORLd BANK, AFricA DEVELOPMENT INDICATORS 2010, at 15 tbl.4 (2010), available at http:/siteresources.worldbank.org/ AFRICAEXT/Resources/english_essay_adi2010.pdf.

167 See, e.g., Rwanda National Police and the Drive Against Comption, RWANDA NAT'L POLICE (Feb. 12, 2013), http://www.police.gov.rw/content/rwanda-national-police-and-drive-against-corruption. 
rather than the efforts of the $\mathrm{ABC}$ in implementing the Corruption Convention. Further, it should be noted that these four countries have not completely eradicated corruption; however, when compared to other African countries, these four countries are doing significantly better on the issue of corruption. As of July 8, 2010, Botswana and Cape Verde have not signed or ratified the Corruption Convention, while Mauritius has signed but has not ratified the convention. ${ }^{168}$ In contrast, Rwanda signed the Corruption Convention on December 19, 2003, and ratified it on June 25, 2004. ${ }^{169}$ The ABC should encourage Botswana, Cape Verde, and Mauritius to ratify the Corruption Convention to set an example for other African states and to further develop and share best practices.

The Corruption Convention provides that in electing the members of the $\mathrm{ABC}$, the $\mathrm{AU}$ must ensure adequate gender representation and equitable geographical representation. ${ }^{170}$ Rather than focusing on geographic representation in selecting $\mathrm{ABC}$ members, the World Bank corruption rankings (or the rankings of other well respected international institutions) should be factored into the election requirements for $\mathrm{ABC}$ members. Countries, such as Rwanda, that have a low indicator or ranking for corruption should have a representative on the $\mathrm{ABC}$. Representatives from such countries may provide invaluable guidance to the $\mathrm{ABC}$ on eliminating corruption. In addition to enacting laws to combat corruption after the 1994 genocide, Rwanda has actively prosecuted political leaders and civil servants who have engaged in acts of corruption ${ }^{171}$ and has established a number of institutions to combat corruption, such as the Office of the Ombudsman and the Anti-Corruption Unit. ${ }^{172}$ Rwanda also actively participates in NEPAD's peer review program, a mechanism that ensures that the policies and practices of African countries incorporate certain political, economic, and democratic principles. ${ }^{173}$ The steps taken by Rwanda to combat corruption-related issues should be noted by the $\mathrm{ABC}$.

\footnotetext{
168 Ratification Status Corruption Convention, supra note 146

169 Id.

170 Corruption Convention, supra note 145, art. 22(2).

171 Marie Chêne, Transparency Int'I, U4 Expert Answer: Overview of Corruption in Rwanda, U4 ANTICORRUPTION ResourCE CENTRE 4-5 (Apr. 16, 2008), http://www.u4.no/publications/overview-of-corruptionin-rwanda/downloadasset $/ 370$.

$172 I d$. at 5-6.

$173 \mathrm{ld}$.
} 


\section{E. NEPAD Democracy Declaration}

With the support of the European Union, NEPAD was established in 2001 by African states in Abuja, Nigeria. ${ }^{174}$ The central goals of the newly created NEPAD were to promote peace, security, and human rights, and to foster the creation of democratic institutions throughout the African continent. ${ }^{175}$ South Africa, Nigeria, Algeria, Egypt, and Senegal were the five principal founding member countries of NEPAD. ${ }^{176}$

After NEPAD was created, member states of the AU adopted the NEPAD Democracy Declaration in an effort to foster economic development and eliminate poverty via the promotion of democracy. ${ }^{177}$ Like the Lomé Declaration and the Elections Declaration, the NEPAD Democracy Declaration is a non-binding legal instrument, and therefore member states are not legally obligated to comply with the provisions of the NEPAD Democracy Declaration. ${ }^{178}$ The NEPAD Democracy Declaration acknowledges that in order to achieve socio-economic development in Africa, the AU must promote democracy and good political governance in African states. ${ }^{179}$ The NEPAD Democracy Declaration specifically reaffirms the AU's commitment to the promotion of democracy and the protection of human rights associated with democracy, including, but not limited to, equality of all citizens before the law, the right to form and join political parties and trade unions, and the inalienable

174 See U.N. Economic Comm'n for Afr., The New Partnership for Africa's Development (NEPAD) 59 (Oct. 2001), http://www.uneca.org/nepad/Media-Dialogue/NEPAD_Framework_Document.pdf [hereinafter NEPAD]

175 Id. para. 49. It has been argued that the document establishing NEPAD is a non-binding instrument. See Renee Ngamau, The Role of NEPAD in African Economic Regulation and Integration, 10 LAw \& Bus. REV. AM. 515, 520-21, 536 (2004) (arguing that NEPAD strategy moves away from the traditional hard law binds of treaties encapsulated in regional economic communities and other economic initiatives, towards a soft law mechanism); see also Serges Alain Djoyou Kamga, Human Rights in Africa: Prospects for the Realisation of the Right to Development Under the New Partnership for Africa's Development 255-56 (June 2011) (L.L.D. thesis, University of Pretoria), available at http://upetd.up.ac.za/thesis/available/etd-01252012$082319 /$ unrestricted/05chapter5.pdf.

176 History, NEPAD, http://www.nepad.org/history (last visited Aug. 13, 2012).

177 See Declaration on Democracy, Political, Economic and Corporate Governance, Annex I, O.A.U. Doc. AHG/235 (XXXVIII) (July 8, 2002) [hereinafter NEPAD Democracy Declaration]. While the NEPAD Democracy Declaration addresses not only democracy and political governance but also economic and corporate governance and socioeconomic development, this Article focuses on the democracy and political good governance provisions of the NEPAD Democracy Declaration. See id.

178 INT'L FED'N FOR HUMAN RTGHTS, A HUMAN RIGHTS APPROACH TO THE NEW PARTNERSHIP FOR Africa's Development (NEPAD) AND the African PeER REVIEW Mechanism (APRM) 47 (2004), available at http://www.fidh.org/IMG//pdf/NEPAD_ANGL_cadre.pdf.

179 NEPAD Democracy Declaration, supra note 177 , paras. 5-6. 
right of the individual to participate in free and fair elections. ${ }^{180}$ The NEPAD Democracy Declaration established an action plan that would, among other things: revise the national constitutions of African countries to reflect democratic principles and accountable governance; promote free and fair political representation; ensure adherence by African countries to the AU's position on unconstitutional changes of government and decisions by the AU aimed at promoting democracy, peace, and security; create oversight bodies in each African country that would ensure free and fair elections; and increase public awareness of the human rights and democratic principles contained in the African Charter. ${ }^{181}$

Despite the laudable goals and action plan set forth in the NEPAD Democracy Declaration, the declaration fails to make any specific reference to enforcement. How will the AU handle recalcitrant member states that refuse to implement the action plan? The NEPAD Democracy Declaration is silent on this issue, except for a reference to the African Peer Review Mechanism ("APRM"). ${ }^{182}$ Perhaps the AU failed to provide additional guidance on the issue of enforcement in the NEPAD Democracy Declaration because of the non-binding nature of the declaration. It is likely that state compliance will be obtained when compliance is in a state's best interest.

The APRM is responsible for reviewing the progress of African states in adopting and implementing the goals of NEPAD as well as addressing ongoing problems with state compliance. ${ }^{183}$ However, states are required to separately accede to the APRM. ${ }^{184}$ Thus, countries have the option of acceding to NEPAD but not the APRM. While the inclusion of the APRM in the NEPAD development process is notable, the separate voluntary accession requirement of the APRM potentially hinders the ability of the APRM to promote good governance across the African continent. For example, as of January 29,2011 , only thirty of the fifty-four member states of the AU have

180 Id. para. 7

181 Id. paras. $12-14$

$182 \mathrm{Id}$. paras. 6, 28 .

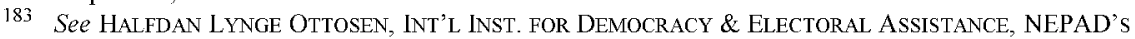
Contribution to Democracy and Good Governance in Africa 7 (2010), available at http://www.idea. int/resources/analysis/upload/Ottosen_low_2.pdf.; see also The New Partnership for Africa's Development (NEPAD): The African Peer Review Mechanism Assembly (APRM), Annex II, OAU Doc. AHG/235 (XXXVIII) (July 8, 2002) [hereinafter APRM Declaration].

184 See APRM Declaration, supra note 183, para. 4. 
voluntarily acceded to the APRM. ${ }^{185}$ The NEPAD Democracy Declaration acknowledges that the APRM seeks to promote compliance with the democratic principles and goals contained in the NEPAD Democracy Declaration. ${ }^{186}$ If the APRM is to be instrumental in promoting the democratic principles contained in the NEPAD Democracy Declaration, it is critical that all member states of the AU be required to accede to the APRM.

Additionally, the APRM is only effective to the extent that it is actually being utilized by member states. As previously noted, thirty member states of the $\mathrm{AU}$ have acceded to the APRM; however, during the period between January 2006 and January 2011, only fourteen of these thirty states were actually peer reviewed by the APRM. ${ }^{187}$ The declaration establishing the APRM ("APRM Declaration") provides that after the initial country review, which must be carried out within eighteen months of a country becoming a member of the APRM process, countries must submit to a periodic review process that takes place every two-to-four years. ${ }^{188}$ Thus, perhaps the fact that only fourteen member countries were peer reviewed during the five year period between January 2006 and January 2011 is due in part to the peer-review time period established in the APRM Declaration. The APRM Declaration also provides that the APRM may conduct country reviews if there are early signs of impending political or economic crises. ${ }^{189}$ However, despite the fact that Egypt has faced political turmoil since 2010, the APRM website acknowledges that "[n]ot much has happened to the country's APRM process in recent times" and notes that "Egypt has not yet received an Advance Mission." ${ }^{5190}$ It is likely that the APRM's failure to take appropriate actions in Egypt are due in part to the AU's lack of political will.

185 The following African states participate in the APRM as of January 29, 2011 : Algeria, Angola, Benin, Burkina Faso, Cameroon, Congo, Djibouti, Egypt, Ethiopia, Gabon, Ghana, Kenya, Lesotho, Liberia, Malawi, Mali, Mauritania, Mauritius, Mozambique, Nigeria, Rwanda, Sao Tome \& Principe, Senegal, Sierra Leone, South Africa, Sudan, Tanzania, Togo, Uganda, and Zambia. African Peer Review Mechanism (APRM), NEPAD, http:/www.nepad.org/economicandcorporategovernance/african-peer-review-mechanism/about/ (last visited Aug. 13, 2012).

186 See NEPAD Democracy Declaration, supra note 177, para. 28.

187 The following fourteen African countries have been peer reviewed by the APRM between January 2006 and January 2011: Ghana, Rwanda, Kenya, South Africa, Algeria, Benin, Uganda, Nigeria, Burkina Faso, Mali, Mozambique, Lesotho, Mauritius, and Ethiopia. African Peer Review Mechanism (APRM), supra note 185 .

188 See APRM Declaration, supra note 183 , para. 13

189 ld.

190 Country Overview: Egypt, AFR. PEER REV. MECHANISM, http://aprm-au.org/knowledge-network/egypt (last visited Aug. 14, 2012) (emphasis omitted). 
The APRM Declaration, like the NEPAD Democracy Declaration, is unclear on the issue of enforcement. ${ }^{191}$ What happens if the APRM recommends that a country adopt certain measures as contemplated in the APRM Declaration to ensure compliance with the democratic principles or good governance goals and the country fails to comply? The NEPAD Democracy Declaration and the APRM Declaration do not address the issue of enforcement. $^{192}$ Both the APRM Declaration and the NEPAD Democracy Declaration should include an enforcement mechanism. The mechanism at the very least should refer non-compliant countries to the Assembly of the AU, the supreme organ of the $A U$, which has the power to issue sanctions or prevent a non-compliant state from participating in the $A U$ pursuant to the terms of the Constitutive Act. ${ }^{193}$

It should be noted that pursuant to the governance structure of NEPAD, the NEPAD Heads of State and Government Orientation Committee ("HSGOC") reports to the AU Assembly and makes recommendations for adoption by the AU Assembly. ${ }^{194}$ Thus, technically, if a recommendation has been made by the HSGOC with respect to a non-compliant state, the AU Assembly has the power to review the recommendation and decide whether to enforce it. However, the NEPAD Democracy Declaration arguably contemplates that it is the responsibility of the APRM and not the HSGOC to promote the NEPAD Democracy Declaration. Further, even if the HSGOC is responsible for the promotion of the NEPAD Democracy Declaration, the fact still remains that neither the NEPAD Declaration nor the APRM Declaration specifically

191 Supra note 182; see also APRM Declaration, supra note 183. It should be noted that in describing the peer review process, the APRM Declaration provides that six months after a report generated by the APRM has been considered by the heads of state and government of participating member countries, it should be formally and publicly tabled in key regional and sub-regional structures such as the Pan-African Parliament, the AU Human Rights Commission, the PSC, and the Economic, Social and Cultural Council of the AU. APRM Declaration, supra note 183, para. 24. Perhaps this language is intended to mean that once the APRM makes a recommendation and a country fails to comply, the recommendation can be submitted for approval to the AU and other key regional structures. Similarly, the APRM Declaration indicates that the heads of state and government of the participating member countries may place a non-compliant country on notice of its intentions to proceed with appropriate measures. Id. para. 23. However, "appropriate measures" are not defined in the APRM Declaration. See id. Therefore, it is unclear what power, if any, participating heads of state and governments have to hold non-compliant states accountable

192 See APRM Declaration, supra note 183; NEPAD Democracy Declaration, supra note 177. The NEPAD Democracy Declaration states that member states must enforce the rule of law, equality of all citizens, individual and collective freedoms, and equality for all. NEPAD Democracy Declaration, supra note 177, para.

7. However, the NEPAD Democracy Declaration does not establish enforcement measures.

193 See Rules of Procedure of the Assembly of the AU, supra note 109, r. 4(g).

194 See NEPAD Governance Structures, NEPAD, http://www.nepad org/nepad-governance-structures-0 (last visited Aug. 14, 2012). 
establishes an enforcement mechanism or references the power of the AU Assembly to sanction member states and exclude states from participation in the AU. ${ }^{195}$

Despite the existence of the NEPAD Democracy Declaration, Africa continues to struggle with the lack of true democracy. For example, Angolan President José Eduardo Dos Santos, Congolese President Denis Sassou Nguesso, and Zimbabwean President Robert Mugabe still control their respective countries after years of being in power. ${ }^{196}$ These leaders have perpetuated their own power by creating "fictional democracies" which appear to incorporate certain aspects of democracies, such as a dual-party system and competing political parties, but a full democracy is never truly achieved. ${ }^{197}$ NEPAD's inability to achieve widespread democracy in Africa is due in part to the non-binding nature of the NEPAD Democracy Declaration and the APRM Declaration, the under-use of the APRM, and the lack of enforcement measures, in the APRM Declaration and the NEPAD Democracy Declaration. ${ }^{198}$ Therefore, when a democracy declaration is inadequately drafted, fails to include an effective enforcement mechanism, and is underused, it is highly unlikely that the adoption of such a declaration would lead to widespread democracy.

The African Charter, Constitutive Act, Lomé Declaration, Elections Declaration, Corruption Convention, and the NEPAD Democracy Declaration each represent prior efforts by the AU and its predecessor the OAU to promote democracy in Africa. While some African countries, such as Mauritius, have been able to achieve a viable democracy, most African countries continue to struggle with establishing democracy. ${ }^{199}$ In fact, many African countries such

195 See supra Part II.E.

196 Isaac Esipisu, Will 20/2 See More Strong Men of Africa Leave Office?, REuTERS: AFr. NEWS BLOG (Dec. 30, 2011), http://blogs.reuters.com/africanews/2011/12/30/will-2012-see-more-strong-men-of-africaleave-office/

197 See Angola: Freedom in the World 2012, FREEDOM HousE, http://www freedomhouse org/report/ freedom-world/2012/angola (last updated Mar. 20, 2013); Congo, Republic of (Brazzaville): Freedom in the World 2012, FREEDOM HOUSE, http:/www freedomhouse org/report/freedom-world/2012/congo-republicbrazzaville (last updated Mar. 20, 2013); Zimbabwe: Freedom in the World 2012, FREEDOM HouSE, http:// www. freedomhouse.org/report/freedom-world/2012/zimbabwe (last updated Mar. 20, 2013).

198 In February 2010, the AU revised the governance structure of NEPAD. See NEPAD Governance Structures, supra note 194. The NEPAD secretariat was transformed into an implementation agency and the NEPAD Planning and Coordinating Agency with the AU Commission now has supervisory authority over this agency. $1 d$. The NEPAD Heads of State and Government Implementation Committee was transformed into the NEPAD Heads of State and Government Orientation Committee. Id.

199 See African Democracy: A Glass Half-Full, ECONOMIST, Mar. 31-Apr. 6, 2012, at 57, 57. 
as Zambia are democratic but continue to face serious challenges, while other countries such as Cameroon and Burkina Faso are subject to authoritarian rule. $^{200}$

As indicated by the foregoing discussion, the earlier instruments adopted by the AU member states to promote democracy failed to lead to the widespread establishment of liberal democracies in Africa. This is due to the fact that many of these instruments: (1) failed to include effective enforcement provisions; (2) were non-binding - and the instruments that were binding were not ratified by all member states; (3) were inadequately drafted; and/or (4) were under-used by the AU. The failure of these previous instruments illustrate that adequately drafted regional instruments, widespread state ratification, effective enforcement provisions, and sound use of binding regional instruments are needed to foster liberal democracies. Additionally, many of these earlier instruments were adopted in a piecemeal manner to address separate and specific issues related to democracy. For instance, the Elections Declaration applies only to elections, the Corruption Convention is primarily focused on the elimination of corruption, and the Lomé Declaration was aimed at eliminating unconstitutional changes of government. ${ }^{201}$ Additionally, none of these earlier instruments attempted to address all of the elements central to establishing a liberal democracy in one legally binding document. ${ }^{202}$ The ADC is unique because not only does it reflect the AU's most current efforts to foster democracy in Africa, but the ADC is also the first binding regional instrument adopted by $\mathrm{AU}$ member states that attempts to comprehensively address all of the elements necessary for the establishment of liberal democracies.

\section{F. Colonialism and Democracy in Africa}

Arguably, the failure of the AU's previous efforts to promote democracy in Africa is due in part to the history of colonialism in Africa. The history of European colonialism in Africa has contributed to the dearth of viable democratic African countries. For example, many suggest that colonialism has had a negative impact on the development and growth rate of former African

\footnotetext{
$200 \mathrm{Id}$. at 57 illus.

201 Corruption Convention, supra note 145, arts. 2-3; Elections Declaration, supra note 117, art. 2; Lomé Declaration, supra note 102.

202 See discussion of the central elements of liberal democracy supra Part I.
} 
colonies. $^{203}$ Former colonial powers generally ruled Africa through indirect rule. ${ }^{204}$ Under indirect rule, the colonial power selected one indigenous group to rule over its colony, and this led to artificial distinctions among indigenous groups; that is, the privileged/ruling indigenous group and all other nonprivileged indigenous groups. ${ }^{205}$ The colonial power then instructed the privileged indigenous group to direct the resources of the colony to the colonial power and, in many instances, the resources of the non-privileged indigenous group were consumed and exploited for the benefit of the colonial power. ${ }^{206}$ Once the colonial power granted independence to African colonies, the privileged indigenous group normally retained political power. ${ }^{207}$ In Rwanda and Burundi, the Tutsis were the privileged indigenous group appointed by Germany and Belgium during colonialism, and the Tutsis continued to control the government of Burundi after independence. ${ }^{208}$ Some have suggested that the history of political disputes in Rwanda between the Tutsis and the Hutus, the non-privileged group during colonial rule, and the continued political instability in Burundi are directly related to the policies imposed by former colonial powers. ${ }^{209}$

The policies adopted by former colonial powers: exploited the resources of African countries; created artificial distinctions among indigenous groups; which ultimately created distrust and animosity between these groups; and have had a long lasting negative impact on the political development of African countries. ${ }^{210}$ Political instability in African countries has also been attributed to the artificial geographic boundaries created by colonial powers. ${ }^{21}$ Such boundaries were established by colonial powers "with little regard for the

203 See Nobuhiro Mizuno \& Ryosuke Okazawa, Colonial Experience and Postcolonial Underdevelopment in Africa, 141 Pub. CHOICE 405, 405 (2009).

$204 \mathrm{Id}$. at 406.

$205 \mathrm{Id}$.

$206 I d$.

207 See id.

208 Id. at 416.

$209 \mathrm{Id}$.

$210 I d$. at $405,417-18$. On the other hand, Neve Gordon contends that "colonialism has served as a crucial component in the historical processes through which modern democracies were created and sustained" particularly within the Israeli context. Neve Gordon, Democracy and Colonialism, PROJECT MUSE - THEORY \& EVENT: VOLUME 13, ISSUE 2 (2010), http://muse.jhu.edu/journals/theory_and_event/v013/13.2.gordon.html. In contrast, a 2004 study concluded that a history of colonialism negatively impacts the prospect of democratic survival in former colonies. Michael Bernhard, Christopher Reenock \& Timothy Nordstrom, The Legacy of Western Overseas Colonialism on Democratic Survival, 48 INT'L STUD. Q, 225, 245 (2004).

211 Tayyab Mahmud, Colonial Cartographies, Postcolonial Borders, and Enduring Failures of International Law: The Unending Wars Along the Afghanistan-Pakistan Frontier, 36 BROOK. J. INT'L L. 1, 50 (2010). 
history, culture, or geography of [a] region, often split cultural units or placed divergent cultural identities within a common boundary."212 Additionally, issues of good governance in Africa are also directly related to poor economic development in African countries. ${ }^{213}$ Therefore, notwithstanding the failure of the AU's prior efforts to promote democracy in Africa through the adoption of various instruments as discussed above, the history of colonialism in Africa has seriously impeded the ability of the AU to achieve widespread democracy in African countries.

Despite the effects of colonialism in Africa and the AU's prior failed efforts, countries such as Botswana and Mauritius have proven that sustainable liberal democracies can be achieved in Africa. ${ }^{214}$ Ghana also serves as an example that democratic stability can be achieved in Africa. ${ }^{215}$ In many instances, the death of a president can lead to a coup as was the case in Guinea in 2008 and Togo in 2005; however, after the death of Ghana's democratically elected president John Atta Mills on July 24, 2012, the vice president, John Mahama, was immediately sworn in as president in accordance with Ghana's constitution. ${ }^{216}$ Mahama was subsequently elected president in December 2012 in an election that was deemed free and fair by the African regional community. ${ }^{217}$ The ADC reflects the AU's commitment to the promotion of liberal democracies. Combined with effective enforcement, use, and the resolution of local conditions that may hinder democratic development, the $\mathrm{ADC}$ has the potential to facilitate the creation of liberal democracies in Africa. Part III provides a comparative analysis of the ADC and the ODC.

212 Id.

213 Mizuno \& Okazawa, supra note 203, at 409

214 See supra notes 4, 63-64 and accompanying text.

215 See generally Janai S. Nelson, Fair Measure of the Right To Vote: A Comparative Perspective on Voting Rights Enforcement in a Maturing Democracy, 18 CARDOZO J. INT'L \& COMP. L. 425 (2010) (arguing that Ghana is a maturing democracy that has successfully resolved problems related to the under-enforcement of the constitutional right to vote)

216 Francis Kokutse \& Krista Larson, John Mahama, Ghana VP, Sworn In Hours After President's Death, HuFFINGTON POST (July 24, 2012, 6:21 PM), http:/www huffingtonpost.com/2012/07/24/john-mahamaghana-vp-sworn-in_n_1700339.html.

217 Ghana Election: John Mahama Declared Winner, BBC NEws (Dec. 10, 2012), http:/www.bbc.co.uk/ news/world-africa-20661599. It should be noted that the opposition in Ghana contested the election. Id. 


\section{THE AFRICAN DEMOCRATIC CHARTER AND THE OAS DEMOCRATIC CHARTER}

Compared to the European and Inter-American human rights regimes, the African human rights regime is the youngest and least developed of the three. $^{218}$ The potential lessons learned by these older regimes in adopting similar legal instruments may be useful to the AU. ${ }^{219}$ Moreover, the AU has faced severe criticism regarding its efficacy in promoting democracy and protecting human rights. Comparing the regional instruments of the OAS and the AU may be helpful in identifying areas in which the AU is excelling and areas in which more work is needed. The OAS has also expressed its support for deepened cooperation between the $\mathrm{AU}$ and the OAS to "encourage the adoption of regional democracy charters and cooperative initiatives and . . to support their implementation ...."220 Additionally, senior officials of the AU and OAS attended a democracy forum in 2007 to address multilateral regional efforts for the promotion and defense of democracy in Africa and the Americas. ${ }^{221}$ The OAS and the AU continue to struggle to achieve democracy in Latin America and Africa, respectively. In light of the commitment toward cooperation between the AU and the OAS and the continued problems that both organizations face with respect to promoting democracy, a comparative analysis of the ODC and the ADC is particularly useful in identifying areas in which the ADC may be strengthened.

The comparative analysis that follows identifies the following changes which should be made to the ADC: (1) democracy should be established as a legal right; (2) the ADC should provide guidance to member states on appropriate presidential term limits; (3) the ADC should be amended to remove the requirement that democratic initiatives must fail prior to the suspension of state membership in the AU; (4) the ADC should establish the specific chargeable offenses which may be brought against perpetrators of unconstitutional changes of government and identify the African court that has jurisdiction to hear such cases; (5) the ADC should authorize sanctions where

218 Henry J. Steiner et al., International Human Rights in Context: Law, Politics, Morals 504 (3d ed. 2008).

219 This Article does not address the instruments adopted by the European Union to promote democracy in Europe because of the historical and current political differences between many European and African countries. In contrast, many Latin American countries have a similar history of colonialism and continue to struggle to achieve economic and political stability.

220 Support for Enhanced Interregional Cooperation with the African Union, OAS A.G. Res. 2419 (XXXVIII-O/08), para. 1, O.A.S. Doc. OEA/Ser.P/XXXVII-O.2 (Vol. 1) (June 3, 2008).

221 Id. pmbl.; see also supra text accompanying note 18 . 
subversive tactics harm the democratic process of a state but do not rise to the level of an unconstitutional change of government; (6) the AU must provide guidance on the level of proof that is necessary to demonstrate that a member state instigated an unconstitutional change of government; (7) the ADC should be revised to clearly establish the right of individuals and NGOs to bring complaints regarding violations of the $\mathrm{ADC}$ before the $\mathrm{AU}$, the appropriate African court, or the AU Human Rights Commission; (8) the ADC should be amended to specifically acknowledge workers' rights, labor rights, and the rights established by the U.N. International Labor Organization Declaration on Fundamental Principles and Rights at Work ("ILO Declaration"); (9) the ADC should articulate the DEAU's role in conducting electoral observer missions and provide that electoral observer missions will be conducted by leading experts and national electoral bodies from African countries that rank highly on international democracy indices such as Ghana, Rwanda, and Mauritius; (10) the ADC should be amended to establish the specific disciplinary measures that the AU will impose for violations of the general provisions of the ADC such as a state's obligation to promote gender equality; and (11) the ADC should authorize member states to combine the required ADC state reports with state reports that must be made under other $\mathrm{AU}$ instruments.

\section{A. Comparative Analysis of the OAS Democratic Charter and the African Democratic Charter}

Both the ODC and the ADC were adopted to promote liberal democracies in Africa and the Americas. AU Commissioner for Political Affairs, Julia D. Joiner, explained at a ministerial meeting of the AU in April 2006 that the ADC, at the time still in the draft stage, would be a regional instrument that reflects the will and commitment of the AU to "consolidate the rule of law and democracy, [and] promot[e] good governance, lasting peace and sustainable development." 222

The OAS member states adopted the ODC to "strengthen and preserve representative democracy in the hemisphere." ${ }^{223}$ As is the case with the ADC,

222 AU Ministers Meet To Review Lome Declaration, PEOPLE's DAILY ONLINE (Apr. 7, 2006), http:// english.peopledaily.com.cn/200604/07/eng20060407_256578.html.

223 Democracy Promotion \& Human Rights, U.S. PERMANENT Mission ORG. AM. STATES, http://www. usoas.usmission.gov/democracy.html (last visited June 18, 2012); see also OAS, Tenth Anniversary of the Inter-American Democratic Charter, http//www.oas.org/en/democratic-charter/ (last visited Aug. 14, 2012). At the 2003 Dialogue for Democracy Conference facilitated by the U.S. Secretary of State, representatives of the AU and the OAS met to address the ODC and the promotion of democracy in Africa and the Americas. See Dialogue on Democracy List of Participants, U.S. DEPT. ST. ARCHIVE (June 12, 2003), 
the essential objectives of the ODC include: (1) "respect for human rights and fundamental freedoms"; (2) "periodic, free, and fair elections"; (3) "[t]ransparency in government activities"; (4) "respect for social rights"; (5) "exercise of power in accordance with the rule of law"; (6) "the pluralistic system of political parties and organizations"; (7) "the separation of powers and independence among the branches of government"; (8) "elimination of all forms of discrimination"; and (9) "the right and responsibility of all citizens to participate in decisions relating to their own development." 224

\section{Democracy as a Legal Right}

The ODC clearly establishes democracy as a legal right to which every individual living in the Americas is entitled. ${ }^{225}$ More specifically, Article 1 states, "[t]he peoples of the Americas have a right to democracy and their governments have an obligation to promote and defend it." ${ }^{226}$ While one of the objectives of the ADC is to promote adherence to principles of democracy and respect for human rights, ${ }^{227}$ the $\mathrm{ADC}$, unlike the $\mathrm{ODC}$, does not go so far as to specifically recognize democracy as a legal right to which every African citizen is entitled. 228

The ODC establishes obligations on member states to promote and observe democratic principles, while simultaneously establishing the right of citizens of the Americas to live in democratic countries, as well as "the right and responsibility of all citizens to participate in decisions relating to their own development. ${ }^{, 229}$ In contrast, the ADC simply creates obligations on member states rather than focusing on the rights of African citizens. For example, the following key phrases appear repeatedly in the narrative of the ADC: "State

http:/2001-2009.state.gov/g/drl/r1s/21477.htm; Dialogue on Democracy Summation of Best Practices and Key ldeas, U.S. DEPT. ST. ARCHIVE (June 18, 2003), http:/2001-2009.state.gov/g/drl/rls/21692.htm.

224 Compare Inter-American Democratic Charter, arts. 3-4, 6, 9, adopted Sept. 11, 2001, 40 I.L.M. 1289 [hereinafter $\mathrm{ODC}]$, with $\mathrm{ADC}$, supra note 1, art. 3.

225 ODC, supra note 224 , art. 1. For a detailed discussion of democracy as a legal right under the ODC, see Enrique Lagos \& Timothy D. Rudy, In Defense of Democracy, 35 U. MIAMI INTER-AM. L. REV. 283 (2004). See also John W. Graham, FOCAL, A Magna Carta for the Americas The Inter-American Democratic Charter: Genesis, Challenges and Canadian Connections (2002), available at http://epe.lac-bac.gc.ca/100/200/300/cdn_foundation_americas/policy_paper-e/2002/02-09/iad_charter.pdf.

226 ODC, supra note 224 , art. 1.

227 ADC, supra note 1, art. 2(1)

228 Compare ODC, supra note 224, art. 1, with ADC, supra note 1, art. 2(1). It should be noted that while the ADC does not explicitly recognize democracy as a legal right. Article 4(2) of the ADC provides that state parties are obligated to "recognize popular participation through universal suffrage as the inalienable right of the people." ADC, supra note 1, art. 4(2)

229 ODC, supra note 224 , arts. 1,6 . 
Parties shall"; "State Parties undertake"; "State Parties re-affirm"; "State Parties may"; and "State Parties agree."230 This overreliance on the obligations of state parties represents a "top-down" approach to promoting democracy.

In contrast, a "bottom-up" approach to democracy would focus on granting rights to African citizens and facilitating the exercise of such rights. Given the fact that the $\mathrm{ADC}$ has been described by the $\mathrm{AU}$ as an instrument that is intended to promote long lasting security and democracy, ${ }^{231}$ it is interesting that democracy was not established as a legal right and additional fundamental human rights were not recognized or clearly re-articulated in the $A D C{ }^{232}$ Perhaps the lack of such rights in the ADC is not surprising since many African countries do not appear to be seriously committed to democratic accountability; ${ }^{233}$ and therefore, these countries may be disinclined to grant more rights to their citizens or to ratify an instrument that re-articulates the fundamental rights of citizens. The failure of the ADC to establish democracy as a legal right does not necessarily indicate that all African leaders believe that Africans are not entitled to democracy; however, it represents a somewhat different approach to the discourse and rhetoric of democracy that may be due in part to historical regional differences.

Leading member states of the OAS include two countries that have historically been referred to as leaders in the fight for democracy and that have expressed support for the adoption and promotion of the ODC: the United States and Canada. ${ }^{234}$ During OAS meetings regarding the ODC, former U.S.

230 ADC, supra note 1, arts. 3-19, 23.

231 Press Release on the ADC, supra note 107

232 See ADC, supra note 1. For the most part, the ADC contains only general references to "human rights." See id. arts. 4-6. The only human rights that are continually referenced in the ADC are the rights to freedom of expression, freedom of the press, and equal protection. $I d$. arts. $2(10), 10(3), 27(8)$. The right to freedom of association, human dignity, and the right to property are not explicitly referenced in the ADC. See id.

233 See Changing the Constitution To Remain in Power, FR. 24 (Oct. 23, 2009), http://www.france24. com/en/20091023-changing-constitution-remain-power

234 See Democracy Promotion \& Human Rights, supra note 223; José Miguel Insulza, Twenty Years Later: Canada's Role in the OAS and the Hemisphere, FoCAL, http:/www.focal.ca/en/publications/focalpoint/ 321-october-2010-jose-miguel-insulza-en (last visited Mar. 20, 2012). While the United States and Canada have expressed support for the OAS and the ODC it is important to note that, as of June 30, 2010, neither country are party to the American Convention on Human Rights, the legal instrument that establishes the InterAmerican Commission on Human Rights and the Inter-American Court on Human Rights. See OAS, Signatories and Ratifications of the American Convention on Human Rights, http://www.oas.org/dil/treaties B-32_American_Convention_on_Human_Rights_sign.htm (last visited Mar. 20, 2013) [hereinafter American Convention Signatories and Ratifications]; see also OAS, Table: Signatures and Current Status of Ratifications of Conventions and Protocols as of February 2012, http:/www.oas.org/en/iachr/mandate/Basics/todasRatEng. pdf (last visited Mar. 20, 2013). 
Secretary of State Colin Powell conveyed U.S. President George W. Bush's support for adoption of the ODC. ${ }^{235}$ Powell later stated that "the Charter has grown to become a defining standard of democratic ideals in the Americas."236 Similarly, during the 2009 Honduras crisis, President Barack Obama called on "all political and social actors in Honduras to respect democratic norms, the rule of law and the tenets of the [ODC]. ${ }^{237}$ Canadian representatives were very involved in drafting the ODC. ${ }^{238}$ During the drafting process, Canadian representatives placed the following Statement of Understanding in OAS records:

Canada understands ... that the right to democracy [as described in the ODC] is the right of individuals to the elements of democracy, as set out in relevant international instruments. We acknowledge that states have the obligation to promote and defend the individual human rights which constitute the elements of democracy. ${ }^{239}$

Canada has also provided support to the Carter Center, an organization that encourages the promotion and application of the ODC. ${ }^{240}$ In contrast to the support given to the ODC by leading member states of the OAS, the ADC has not received similar support by member states of the AU, as evidenced by the fact that thirty-eight member states of the AU have not yet ratified the charter. $^{241}$ Moreover, the few member states that do support the ADC do not have the same political clout or reputation as countries such as the United States and Canada, and as a result, these African countries are individually unable to exert significant pressure on non-compliant $A$ frican states to respect and promote liberal democratic ideals. ${ }^{242}$ Thus, the difference in the regional

235 See Colin L. Powell, Reflections on the Inter-American Democratic Charter, AMÉRTCAS, July/Aug. 2011 , at 32,32 .

$236 \mathrm{Id}$. at 33

237 Press Release, U.S. President Barack Obama, Statement from the President on the Situation in Honduras (June 28, 2009), http://www. whitehouse.gov/the_press_office/Statement-from-the-President-on-thesituation-in-Honduras.

238 Insulza, supra note 234

239 OAS Permanent Council, 1292d mtg. at 17, O.A.S. Doc. OEA/Ser.G CP/ACTA 1292/01 rev. 1 (Sept. 6, 2001).

240 Gov't of Can, Canada And the Americas: Priorities \& Progress 9 (2009), available at http://www.international.gc.ca/americas-ameriques/assets/pdfs/Report2009-eng.pdf.

241 Ratification Status of the ADC, supra note 2.

242 Id. For example, the small country of Mauritania was one of the first member states to support the ADC. Friederike Roder, The African Charter on Democracy Elections and Governance-You Better Take it Seriously!, ONE (Feb. 1, 2012), http//www.one.org/us/2012/02/01/the-african-charter-on-democracyelections-and-governance-you-better-take-it-seriously. Similarly, larger and more powerful African states that have ratified the ADC continue to struggle with issues central to the maintenance of democratic order. Ratification Status of the ADC, supra note 2. For example, Nigeria and South Africa still struggle with 
make-up of the OAS and the AU may be responsible for the fact that the ODC arguably establishes democracy as a legal right while the ADC does not. Of course, the OAS may have been able to establish democracy as a legal right in the ODC because of the non-binding nature of the ODC. Despite the regional differences and the non-binding nature of the ODC, the AU should clearly communicate to its member states that it is committed to promoting democracy by revising the ADC to establish democracy as a legal right to which all Africans are entitled. Additionally, even if the right to democracy is not consistently enforced because of a lack of political will, recognizing a legal right to democracy is beneficial because it may provide individual Africans with a basis for claiming and asserting their own rights. The ability of citizens to assert their own rights and participate in the democratic process is a central feature of liberal democracies.

\section{Unconstitutional Changes of Government and Sanctions}

The representation and protection of diverse interests through constitutional safeguards and electoral contestation are key elements of liberal democracies. ${ }^{243}$ Therefore, the extent to which the ADC seeks to combat unconstitutional changes of government reflects the AU's commitment to the promotion of liberal democratic ideals in African member states. Ratification of the ADC "is significant because it demonstrates the desire within the AU to strengthen the legal framework applicable to unconstitutional changes of government." 244 The provisions of the ADC should enhance the ability of the $\mathrm{AU}$ to combat unconstitutional changes of government throughout the African continent. $^{245}$ Article 23 of the ADC expands the definition of an unconstitutional change of government. ${ }^{246}$ The charter's definition incorporates all of the unconstitutional scenarios set forth in the Lomé Declaration, which are described in Part II.B, ${ }^{247}$ but is more expansive because it includes "[a]ny amendment or revision of the constitution or legal instruments, which is an infringement on the principles of democratic change of government."248

\footnotetext{
corruption. See Nontando Ngmlana, Corruption in South Africa: Defining the Role of Civil Society, AfESISCORPLAN, http://www.afesis.org.za/Local-Governance-Articles/corruption-in-south-africa-defining-the-role-ofcivil-society (last visited Aug. 14, 2012); Nigeria: Anglican Primate to FG-Tackle Corruption, Not Constitution Review, ALLAFRICA (July 28, 2012), http:/allafrica.com/stories/201207280272.html.

243 PINKNEY, supra note 41, at 9 tbl.1.1; accord id. at 12.

244 Omorogbe, supra note 100, at 135.

245 See id. at 137

246 See ADC, supra note 1, art. 23

247 See supra Part II.B.

248 ADC, supra note 1, art. 23(5).
} 
In contrast to the ADC, which specifically defines the events that constitute an unconstitutional change of government, the ODC does not contain a similar definition. Article 19 of the ODC simply acknowledges that "an unconstitutional interruption of the democratic order or an unconstitutional alteration of the constitutional regime that seriously impairs the democratic order ..." creates an obstacle to that government's participation in the OAS. ${ }^{249}$ The terms "unconstitutional interruption" and "unconstitutional alteration" are not defined the ODC. ${ }^{250}$ Thus, the ADC is notable in that it not only clearly provides guidance to member states as to what events qualify as an unconstitutional change of government, ${ }^{251}$ but it also represents a clear effort by the $\mathrm{AU}$ to promote democracy by combating what has become one of the most common means by which certain African leaders continue to perpetuate themselves in power. For example, in 2003 after being in power for almost forty years, President Omar Bongo of Gabon amended the constitution of Gabon to increase the term length from five to seven years. ${ }^{252}$ Similarly, in 1999, Namibia's constitution was amended to permit then President Sam Nujoma to run for a third term, and in 2002 Tunisia's constitution was amended to eliminate all term limits and increase the age limit to seventy-five to permit then President Zine el-Abidine Ben Ali to maintain power. ${ }^{253}$

\section{a. Term Limits}

The lack of a provision in the ADC that specifically establishes a limit on the number and duration of terms that an African leader can stay in power is

249 ODC, supra note 224 , art. 19

250 See ODC, supra note 224. Scholars such as Javier El Hage have argued that while the term "unconstitutional alteration" is not defined in the ODC, the term can be interpreted to include: (1) standard military coups; (2) impeachment coups; and (3) the "gradual, sustained, and systematic erosion of certain essential elements of democracy... [such as] [u]se of public office to silence, harass, or disrupt the association, and activities of members of the political opposition, labor unions, minority groups, or [dissenting] civil society members." See Javier El-Hage, Human Rights Found., The Facts and the Law: Behind the DEMOCRATIC CRISIS OF HONDuRAs, 2009, at 94, 100 (2010) (alteration in original) (citing Shelley A. MeConnell \& Jennifer McCoy, Analytical Review and Recommendations, in COLLECTIVE DEFENSE OF Democracy: Concepts and Procedures 13, 26 (2006); Theodore J. Piccone, International Mechanisms for Protecting Democracy, in Protecting Democracy: International Response), crvailable at http://thehrf.org/HRF TheFactsAndTheLaw_Honduras2009.pdf.

251 See ADC, supra note 1, art. 23(5).

252 Changing the Constitution to Remain in Power, supra note 233.

253 Id.; see also Namibia: Freedom in the World 2006, FREEDOM HOUSE, http://www freedomhouse.org/ report/freedom-world/2006/namibia (last visited Mar. 20, 2013); Tunisia: Freedom in the World 2008, FREEDOM HOUSE, http:/www. freedomhouse.org/report/freedom-world/2008/tunisia (last visited Mar. 20 , 2013). 
glaring. ${ }^{254}$ As previously noted, African heads of state have a long history of amending the legal instruments of their respective countries to retain power. ${ }^{255}$ Although the ADC attempts to address this issue by stating that amending the constitution or legal instruments of a country to infringe on democratic rights and principles is an unconstitutional change of government, ${ }^{256}$ the charter does not go far enough. What if a country's constitution contains no presidential term limits, as was the case in Tunisia after $2002 ?^{257}$ The ADC fails to address this issue. What if the constitution of a particular country is unclear as to the number of terms that a president may serve in office, as was the case in Zimbabwe before $2013 ?^{258}$

While the Zimbabwean constitution imposed a five-year limit on the duration of a president's term in office, it did not specifically contain a limit on the number of terms that a president may serve in office. ${ }^{259}$ In 2013 , a new constitution was passed in Zimbabwe that addressed this issue. ${ }^{260}$ The new Zimbawean constitution limits the president to no more than two terms of five years each. ${ }^{261}$ However, these new term limits would have to apply retroactively to prevent long-serving President Mugabe from running for president in the upcoming elections. ${ }^{262}$ The ADC fails to specifically address a scenario like Zimbabwe's constitution before 2013 or Tunisia's 2002 constitution. Given the tendency of African heads of state to eliminate term limits in existing constitutions, ${ }^{263}$ draft constitutions that do not address term limits, and draft constitutions that establish term limits but which do not apply

254 See Nadjita F. Ngarhodjim, African Charter on Democracy, Elections and Governance: A Critical Analysis, AFRIMAP 5 (May 2007), http://www.afrimap.org/english/images/paper/ACDEGNgarhodjim_EN. pdf.

255 Changing the Constitution to Remain in Power, supra note 233

256 ADC, supra note 1 , art. 23(5).

257 Tunisia: Freedom in the World 2008, FREEDOM HOUSE, http://www.freedomhouse.org/report/freedomworld/2008/tunisia (last visited Mar. 20, 2013). Zine el-Abidine Ben Ali was ousted by the Tunisian people in 2011 during the "Arab Spring." Lin Noueihed, New Tunisia Constitution Ready in October: Speaker, REUTERS, May 11, 2012, available at http:/www.reuters.com/article/2012/05/11/us-tunis-constitutiondeadline-idUSBRE84A0UN20120511.

258 See CONST. OF ZIMBABWE of 1979 (as amended by Amendment Act No. 19 of 2009) $\$ 29(1$ ).

$259 \mathrm{Id}$.

260 See CONST. OF ZIMBABwE of $2013 \$ \$ 91,95$; see also Njabulo Ncube, Zimbabwe: Presidential Term Limits Agreed, ALLAFrICA (Mar. 30, 2012), http://allafrica.com/stories/201203310125.html.

261 CONST. OF ZIMBABWE of $2013 \$ \$ 91,95$.

262 See Simon Allison, Even Zimbabwe's Constitution Waits for Mugabe To Pass the Baton, or Pass Away, GuARDian (Mar. 26, 2013), http:/www.guardian.co.uk/world/2013/mar/26/zimbabwe-mugabeconstitution-die.

263 Changing the Constitution To Remain in Power, supra note 233. 
retroactively, the task of establishing term limits cannot safely be left to African heads of state or rival political parties.

Even when there are competing political parties, as is the case in Zimbabwe where the Zimbabwe African National Union-Patriotic Front, Mugabe's party, ${ }^{264}$ faces significant opposition from the Movement for Democratic Change, ${ }^{265}$ the opposing party may still succumb to pressure to establish term limits that do not apply retroactively. It is likely that the imposition of presidential term limits will facilitate political stability by ensuring peaceful successive democratic changes of government and engender public confidence in the integrity of the government by ensuring respect for constitutional guarantees and human rights. Thus, the AU should provide guidance to member states on establishing appropriate term limits. ${ }^{266}$ Perhaps such guidance would involve using the constitutions of successful African democracies as benchmarks. For instance, Ghana's 1992 constitution provides that a president can serve two four-year terms. ${ }^{267}$ As discussed in Part I of this Article, Ghana experienced a radical democracy under Kwame Nkrumah's rule but the country has been described as a successful African democracy since the adoption of the 1992 constitution, which established the current presidential term limits. In addition to revising the ADC to provide guidance on term limits, effective enforcement of such a provision, along with a grass-roots movement, a cultural shift, and the presence of sufficient local conditions would be necessary to ensure successive democratic changes of government.

An argument can be made that establishing such term limits via the ADC constitutes an unfair interference in the internal affairs of African states in violation of the Constitutive Act. ${ }^{268}$ The Constitutive Act provides that the AU has the power to interfere in the internal affairs of a country only in grave circumstances, namely: war crimes, genocide, and crimes against humanity. ${ }^{269}$ It is unlikely that the failure to respect democratic norms, without more, will

\footnotetext{
264 ZANU PF, http //www zanupf.org.zw/ (last visited Mar. 20, 2013); see also Allison, supra note 262.

265 Movement FOR Democratic ChANGE, http://www. mde.co.zw/ (last visited Mar. 20, 2013); see also Allison, supra note 262 .

266 Rather than establishing a single presidential term limit that would apply to all of the AU's fifty-four member states, the AU should adopt an individualized approach which takes into consideration the unique needs of each African country and which uses similarly situated successful African democracies such as Mauritius, Botswana, and Ghana as a benchmark for establishing presidential term limits in African countries that continue to struggle with achieving democracy.

267 CONST. OF GHANA of 1992 (as amended by Act No. 527 of 1996) § 66(1)-(2)

268 Constitutive Act, supra note 84, art. 4(g)

269 Id. art. 4(h).
} 
qualify as a war crime, genocide, or crime against humanity. However, the Constitutive Act provides that the $\mathrm{AU}$ must function in accordance with "[r]espect for democratic principles, human rights, the rule of law and good governance." 270 As such, the Constitutive Act requires the AU to promote democratic principles in African countries ${ }^{271}$ and therefore, by providing guidance on appropriate presidential term limits in the ADC, the AU is simply complying with the requirements of the Constitutive Act.

It should be noted that there is no international consensus on what constitutes an appropriate presidential term limit. Presidential term limits differ even among developed countries with long-standing democracies. ${ }^{272}$ With respect to the issue of term limits, the African situation is quite unique and should not be compared to developed democratic countries. As previously noted, African leaders have a long history of amending their constitutions to eliminate or extend presidential term limits to perpetuate themselves in power. ${ }^{273}$ This is not the case in many developed countries such as the United States. Therefore, it is evident that the AU must provide guidance to African countries regarding acceptable presidential term limits. This guidance should be achieved via an external instrument, such as the ADC, which cannot be amended unilaterally by the president of a single A frican country that seeks to retain power. Additionally, guidance on appropriate term limits could be provided in conjunction with the NEPAD Democracy Declaration, which establishes an action plan to aid countries to revise their constitutions to reflect democratic principles, as discussed above. ${ }^{274}$

\section{b. Failure of Diplomatic Initiatives}

When compared to prior instruments adopted by the AU, such as the Constitutive Act and the Lomé Declaration, the ADC aggressively deals with unconstitutional changes of government and includes expansive measures and sanctions that may be implemented against the perpetrators of an unconstitutional change of government. For example, Article 30 of the Constitutive Act provides that governments that come to power through

\footnotetext{
270 Id. art. $4(\mathrm{~m})$.

271 See id. art. $3(\mathrm{~g})$

272 For example, the U.S. Constitution limits presidents to two four-year terms. U.S. CoNST. art. $2, \S 1$, amend. XXII, $\$ 1$. In contrast, the United Kingdom has no term limits for prime ministers. Term Limits: How Long Can a World Leader Stay in the Job? , CBC NEws, http://www.cbc.ca/news/interactives/mapleaderterms/ (click "U.K." on the world map) (last visited Aug. 14, 2012).

273 Changing the Constitution to Remain in Power, supra note 233.

274 See supra Part II.E.
} 
unconstitutional means will not be allowed to participate in the activities of the $\mathrm{AU}$, and Article 23 of the Constitutive Act provides that member states that fail to comply with the decisions of the Assembly may be subject to sanctions. $^{275}$ Article 23 and Article 30 are the main provisions of the Constitutive Act that address unconstitutional changes of government. In contrast, the ADC not only recognizes the ability of the AU to suspend members and impose sanctions pursuant to Article 23 and Article 30 of the Constitutive Act, but it also provides that "perpetrators of unconstitutional change[s] of government shall not be allowed to participate in elections held to restore the democratic order or hold any position of responsibility in [the] political institutions of their State." 276

Although the ADC recognizes the power of the Assembly to suspend member states under the Constitutive Act and the power of the PSC to impose sanctions under the AU PSC Protocol, the ADC indicates that the Assembly can exert the power of suspension, and the PSC can issue sanctions, only after diplomatic initiatives have failed. ${ }^{277}$ The ODC contains a similar provision that requires the failure of diplomatic initiatives to suspend a member state that has experienced an unconstitutional interruption of its democratic order. ${ }^{278}$ Despite this similarity between the ODC and the ADC, the inclusion of this language in the ADC poses a potential problem for the AU and should be removed. Neither the Constitutive Act nor the AU PSC Protocol conditions member state suspension or the imposition of sanctions on failed diplomatic initiatives. ${ }^{279}$ The introduction of this "new condition" not only confuses the discourse, but also potentially forces the $\mathrm{AU}$ to first initiate diplomatic efforts to resolve political and humanitarian crises and then adopt a wait-and-see approach to determine if such efforts have failed prior to issuing sanctions or suspending membership in the AU. How long does the AU have to wait to determine if diplomatic initiatives have failed? What are the standards for determining when diplomatic efforts have failed? The ADC fails to provide answers to these questions.

275 Constitutive Act, supra note 84, arts. 23(2), 30.

276 ADC, supra note 1, art. 25(4).

277 Id. art. $25(1)$.

278 ODC, supra note 224, art. 21.

279 Article 30 of the AU Constitutive Act provides that "[g]overnments which shall come to power through unconstitutional means shall not be allowed to participate in the activities of the [African] Union." Constitutive Act, supra note 84, art. 30. Similarly, Article 7(g) of the AU PSC Protocol provides that the PSC must "institute sanctions whenever an unconstitutional change of Government takes place in a Member State, as provided for in the Lomé Declaration." AU PSC Protocol, supra note 94, art. 7(g). 
Further, diplomatic negotiations often involve an intricate dance between rivaling political camps and it may be difficult to determine the exact moment that diplomatic initiatives have failed. As was the case in Madagascar, often the parties will appear to be close to executing an agreement to resolve the crisis and then negotiations will break down, and even after an agreement has been executed, at some point in the future one party may decide not to comply with the terms of the agreement. ${ }^{280}$

When compared to the speed at which other countries and the European Union have issued sanctions, the $A U$ often delays the issuance of sanctions against recalcitrant member states. For example, during the 2009 political crisis in Madagascar, the AU waited one year from the date of the unconstitutional change of government to impose sanctions. ${ }^{281}$ In the world of international politics, effective and swift imposition of targeted sanctions can, in some instances, engender member-state compliance. ${ }^{282}$ Thus, it is crucial that a human rights regime has clear and absolute power to hold recalcitrant member states accountable. Despite the AU's tendency to delay imposing sanctions, the AU has the option under the Constitutive Act and the AU PSC Protocol to impose sanctions and suspend membership immediately in the event of an unconstitutional change of government. ${ }^{283}$ This may no longer be the case as the ADC conditions the imposition of sanctions on the failure of diplomatic efforts ${ }^{284}$ and this may have a long-lasting and negative impact on the ability of the AU to swiftly hold non-compliant member states accountable for violations of the democratic principles contained in the ADC. In ratifying member states that are subject to unconstitutional changes of government, individuals may be able to retain power by using delay tactics to give the appearance of cooperating with diplomatic efforts, as a literal reading of the

280 Madagascar: Freedom in the World 2012, FREEDOM HOUSE, http://www.freedomhouse.org/report/ freedom-world/2012/madagascar (last visited Mar. 20, 2013). For a detailed discussion of the crisis in Madagascar, see Elvy, supra note 72, at 99-104.

281 See AU Peace \& Security Council, Communiqué of the 221st Meeting of the Peace and Security Council, para. 4, A.U. Doc. PSC/PR/COMM.(CCXXI) (Mar. 17, 2010); AU Peace and Security Council, Communique of the 216th Meeting of the Peace and Security Council, para. 8, A.U. Doc. PSC/PR/COMM.1(CCXVI) (Feb. 19, 2010); see also Barry Malone, African Union Imposes Sanctions on Madagascar, REUTERS, Mar. 17, 2010, available at http://uk.reuters.com/article/2010/03/17/idUKLDE62G $21 \mathrm{P}$.

282 See Andrew T. Guzman, A Compliance-Based Theory of International Low, 90 CALIF. L. REV. 1823, 1868 (2002) ("Despite their shortcomings, punitive sanctions should not be dismissed too quickly .... In some situations it is possible to have such sanctions imposed and, as a result, to provide more efficient incentives to states.").

283 AU PSC Protocol, supra note 94, art. 7(g); Constitutive Act, supra note 84, art. 30.

284 See ADC, supra note 1, art. 25(1). 
ADC indicates that the AU cannot impose sanctions or suspend membership in the AU until diplomatic efforts have failed.

\section{c. Chargeable Offenses}

The ADC provides that the "[p]erpetrators of [an] unconstitutional change of government may also be tried before the competent court of the [African] Union." ${ }^{285}$ Although the ADC does not specify the offenses that such individuals will be charged with, some suggest that the charge would be classified as a "crime against democracy." 286 The ADC should be revised to specify the chargeable offenses that may be brought against perpetrators of unconstitutional changes of government. Additionally, it is unclear whether the framers of the ADC intended to establish ad hoc tribunals for war crimes. The ADC also does not specifically identify the African court that will have jurisdiction to hear claims regarding violations of the ADC. The ADC should be revised to answer jurisdictional questions. With the exception of the individual claims procedure, which is discussed below, the ODC does not contain a similar enforcement provision. ${ }^{287}$

\section{d. Subversive Tactics}

Article 24 of the ADC gives the PSC the power to act to maintain constitutional order "[w]hen a situation arises in a [s]tate [p]arty that may affect its democratic political institutional arrangements or the legitimate exercise of power....,288 In other words, this provision authorizes intervention by the PSC to protect a state's democratic political institutions and legitimate government. The AU PSC Protocol authorizes the PSC to issue sanctions in the event of an unconstitutional change of government. ${ }^{289}$ In addition to sanctions such as the denial of transport and communications links with other member states, all of which are referenced in Article 23 of the Constitutive Act, ${ }^{290}$ the ADC also gives the Assembly the power to impose other forms of sanctions against the perpetrators of unconstitutional changes of government, including punitive economic damages. ${ }^{291}$

\footnotetext{
$285 I d$. art. 25(5).

286 Omorogbe, supra note 100 , at 136.

287 See infra Part III.A.iv.

288 ADC, supra note 1 , art. 24

289 AU PSC Protocol, supra note 94, art. 7(g).

290 Constitutive Act, supra note 84, art. 23(2).

291 ADC, supra note 1, art. 25(7).
} 
While these provisions in the ADC are notable, the ADC, like the AU PSC Protocol, authorizes the $\mathrm{AU}$ to sanction instigating states only if state action results in an unconstitutional change of government. ${ }^{292}$ In theory, African leaders may freely destabilize the economy and the governments of other African states without the threat of AU sanctions unless their actions are proven to lead to an unconstitutional change of government. The ADC should authorize the AU to sanction states that use subversive tactics to destabilize democratic order, even if the use of such tactics does not ultimately result in an unconstitutional change of government. Imposing sanctions against states that destabilize governments regardless of whether an unconstitutional change of government occurs will serve as a deterrent to other states that seek to use such practices.

\section{e. Level of Proof}

The ADC provides for sanctions against ratifying member states that are proven to instigate or support "unconstitutional change[s] of government in another state ...."293 The AU should shed light on the level of proof that is needed to show that a member state has instigated an unconstitutional change of government. For example, in June 2012, the U.N. Security Council published a report that accused Rwanda of backing rebels opposed to the government in the Democratic Republic of Congo ("DRC") by "providing weapons, military supplies and new recruits" to the rebels. ${ }^{294}$ The United States, Britain, the Netherlands, and Germany have all suspended portions of aid to Rwanda despite Rwanda's denials of involvement in the DRC conflict. $^{295}$ If Rwanda's alleged backing of the DRC rebels led to an unconstitutional change of government in the DRC, would the U.N. report accusing Rwanda of aiding rebels be enough to satisfy the proof-requirement in the ADC? The ADC is silent on this issue. ${ }^{296}$ Additionally, the recent accusations against Rwanda illustrate that in seeking to utilize the ADC to promote democracy, rather than waiting until an unconstitutional change of

292 Compare ADC, supra note 1, art. 23, with AU PSC Protocol, supra note 94, art. 7(g).

293 Id. art. 25(6).

294 U.N. Group of Experts on the Democratic Republic of the Congo, transmitted by letter dated June 26, 2012 from the Chair of the Security Council Comm. established pursuant to resolution 1533 (2004) concerning the Democratic Republic addressed to the President of the Security Council, para. 3, U.N. Doc. S/2012/348/Add.1, Annex (June 27, 2012).

295 See ADC, supra note 1.

296 Jonny Hogg, Congo's Kabila: Rwanda's Rebel Backing No Secret, ReuTERS, July 29, 2012, available at http $/ /$ af.reuters.com/article/topNews/idAFJOE86S03020120729? sp=true. 
government occurs, the AU must respond quickly to actions by member states, which may destabilize governments in other countries.

\section{Extradition}

The ADC obligates ratifying member states to "bring justice to the perpetrators of unconstitutional changes of government," "take necessary steps to effect their extradition," and ensure that such perpetrators are not given sanctuary. ${ }^{297}$ In contrast, the ODC does not specifically address the issue of extradition. ${ }^{298}$ The ADC also encourages ratifying member states to execute bilateral extradition agreements to facilitate the extradition of perpetrators of unconstitutional changes of government. ${ }^{299}$ Extradition treaties, when properly utilized, may permit the $A U$ to ensure that the perpetrators of unconstitutional changes of government cannot find safe harbors in ratifying member states. Some ratifying member states of the ADC have already executed extradition treaties. For example, South A frica and Lesotho, both ratifying member states of the ADC, have executed an extradition treaty. ${ }^{300}$ Additionally, regional extradition treaties may provide a solution to those ratifying member states that have not executed bilateral extradition treaties. For instance, many of the ratifying member states of the $A D C$, such as Burkina Faso, Ghana, GuineaBissau, Guinea, and Nigeria, are members of the Economic Community of West African States ("ECOWAS"), a regional body aimed at addressing social and political issues and promoting economic integration among its member states. $^{301}$

297 ADC, supra note 1 , art. 25(8)-(9).

298 ODC, supra note 224 . It should be noted that some OAS member states adopted the Inter-American Convention on Extradition. Inter-American Convention on Extradition, Feb. 25, 1981, 1752 U.N.T.S. 177. Recently, the OAS faced significant problems attempting to resolve the extradition of Julian Assange from Ecuador to Britain. For a detailed discussion of the OAS' efforts to resolve the extradition of Assange, see Julian Assange: Ecuador Calls on OAS, UNASUR, ALBA Support Against UK Threat, GLOBAL RES. (Aug. 18 , 2012), http:/www globalresearch.ca/julian-assange-ecuador-calls-on-oas-unasur-alba-support-against-ukthreat/32396. See also Julian Assange Row: Americas Give Ecuador Partial Support, BBC NEws (Aug. 25, 2012), http:/www.bbc.co.uk/news/uk-19377110.

299 ADC, supra note 1, art. 25(10).

300 Treaty on Extradition, Lesotho-S. Afr., done Apr. 19, 2001, GN R644 in GG26375 of 28 May 2004 (S. Afi.).

301 See ECOWAS Member States, ECOWAS COMMISSION, http//www.ecowas.int/ (last visited Aug. 14, 2012). For a general description of ECOWAS, see its website. ECOWAS, http://www.ecowas.int/?lang=en (last visited Mar. 20, 2013) 
The ECOWAS extradition convention was adopted on August 6, 1994 ("ECOWAS Extradition Convention"). ${ }^{302}$ All states that were members of ECOWAS on that date signed the ECOWAS Extradition Convention. ${ }^{303}$ Member states that have ratified the ADC and that are members of ECOWAS may be able to partially fulfill their obligations under the ADC by utilizing the ECOWAS Extradition Convention. The AU has a long history of working with ECOWAS to resolve political crises, as it did after the 2008 coup d'état in Guinea, as well as in the current Mali crisis. ${ }^{304}$ However, the ECOWAS Extradition Convention indicates that the convention is not applicable to political offenses. ${ }^{305}$ The term "political offenses" is not defined in the ECOWAS Extradition Convention. ${ }^{306}$ To the extent that the offense for which the individual is charged is of a political nature, extradition under the ECOWAS Extradition Convention is not permissible. If ratifying member states of the $\mathrm{ADC}$ elect to utilize the ECOWAS Extradition Convention to satisfy the extradition requirements of the ADC, the offenses charged should, when possible, be characterized as human rights violations rather than as "political offenses." This of course may be difficult to do considering the context in which a ratifying member state may seek to utilize the ECOWAS Extradition Convention to satisfy its extradition obligations under the ADC. That scenario would most likely involve an unconstitutional change of government which is arguably an offense of a political nature.

Similarly, Zambia, the Kingdom of Lesotho, and South Africa have all ratified the $\mathrm{ADC}$ and are members of the Southern African Development Community ("SADC"). ${ }^{307}$ The SADC Protocol on Extradition contains a similar limitation on extradition for political offenses. ${ }^{308}$ However, the SADC

\footnotetext{
302 Convention D'Extradition, done Aug. 6, 1994, 27 J.O. CEDEAO 11 [hereinafter ECOWAS Extradition Convention].

303 See id. at 17-19; see also Aderanti Adepoju, Alistair Boulton \& Mariah Levin, Promoting Integration Through Mobility: Free Movement Under ECOWAS 11 n.24 (U.N. High Comm'r for Refugees, Research Paper No. 150, 2007), available at http://Www.unher.org/476650ae2.html.

304 See AleXts ArIEFF, CONG. Research SERV, R41200, GuINEA's NEW Transitional GovernMENT: Emerging Issues for U.S. Policy 1, 4 (2010); see also Press Release, ECOWAS, African Union Endorses All ECOWAS Decisions on Mali, ECOWAS Press Release No. 198/2012 (July 14, 2012), available at http://news.ecowas.int/presseshow.php?nb=198\&lang=en\&annee $=2012$

305 ECOWAS Extradition Convention, supra note 302, art. 4.

306 See id.

307 Compare Ratification Status of the ADC, supra note 2, with Member States, S. Afr. DEv. COMmunTtY, http://www.sadc.int/member-states (last visited Mar. 20, 2013).

308 Southern African Development Community Protocol on Extradition art. 4(a), done Oct. 3, 2002, http://www.sadc.int/files/3513/5292/8371/Protocol_on_Extradiction.pdf [hereinafter SADC Protocol on Extradition].
} 
Protocol on Extradition excludes from the definition of "political offenses" any offense where "State Parties have assumed an obligation, pursuant to any multilateral convention, to take prosecutorial action....,309 The bilateral extradition agreement between the Kingdom of Lesotho and South Africa contains a similar provision that generally prohibits extradition for political offenses, but exempts from the definition of political offenses conduct that requires the extradition of an individual in accordance with a multilateral agreement to which the Kingdom of Lesotho and the Republic of South Africa are parties, such as the ADC. ${ }^{310}$ The ADC specifically obligates member states to take prosecutorial action to bring justice to perpetrators of unconstitutional changes of government or take all steps necessary to effect the extradition of such perpetrators. ${ }^{311}$ Thus, if ratifying member states of the ADC seek to rely on a combination of bilateral and regional extradition conventions or treaties, the $\mathrm{AU}$ and ratifying member states must ensure that these conventions and treaties would permit extradition for, and prosecution of, crimes that occur in connection with an unconstitutional change of government.

Extraditions play an important role in ensuring that individuals who violate international law, democratic principles and human rights are not allowed to escape prosecution. However, the AU has a mixed track record on the issue of extraditions. The AU opposed the ICC's efforts to extradite and prosecute Sudanese President Omar al-Bashir for war crimes in Darfur. ${ }^{312}$ In contrast, the AU encouraged Senegal to extradite the former Chadian President Hisséne Habré for crimes including acts of torture and political killings. ${ }^{313}$ The $\mathrm{AU}$ should establish a consistent track record of supporting extradition of individuals charged with international and political crimes; thereby, clearly expressing to member states the importance of executing and complying with applicable extradition treaties and ICC extradition requests.

\footnotetext{
$309 I d$

310 Treaty on Extradition, supra note 300 , art. 3(1)(b).

311 ADC, supra note 1, art. 25(9).

312 African Union Defies ICC over Bashir Extradition, ABC NEws (AUSTL. BROADCASTTNG CORP.) (July 5, 2009), http://www.abc.net.au/news/2009-07-05/african-union-defies-icc-over-bashir-extradition/1341682.

313 AU to Senegal: Try or Extradite Habre, TIMES LIVE (July 3, 2011), http://www.timeslive.co.za/africa/ 2011/07/03/au-to-senegal-try-or-extradite-habre. Senegal eventually elected to prosecute rather than extradite Habré. Senegal: Hissène Habré Court Opens, Hum. RTS. WATCH (Feb. 8, 2013), http:/www.hrw.org/news/ 2013/02/08/senegal-hissene-habre-court-opens.
} 


\section{Individual Claims}

Another significant difference between the ODC and the ADC is the reference to individual access to the Inter-American system. The ODC provides that any person or group of persons who believe that their human rights have been violated may present claims or petitions to the Inter-American system. ${ }^{314}$ The Inter-American human rights system generally consists of the Inter-American Commission on Human Rights ("IACHR") and the InterAmerican Court on Human Rights ("IAC"). ${ }^{315}$ The IACHR has the ability to receive and review petitions from individuals concerning violations of human rights. ${ }^{316}$ According to Ariel Dulitzky, the IACHR received 7,803 individual complaints between 2003 and $2008^{317}$ and the IACHR initiated the processing of 816 petitions between 2003 and $2008^{318}$

\footnotetext{
314 ODC, supra note 224 , art 8.

315 OAS, American Convention on Human Rights arts. 33, 61, Nov. 22, 1969, 1144 U.N.T.S 123,
} O.A.S.T.S. No. 36 (entered into force July 18, 1978) [hereinafter American Convention]. As of the publication of this Article, the following twenty-four of the thirty-five member States of the OAS have ratified the American Convention: Argentina, Barbados, Bolivia, Brazil, Chile, Colombia, Costa Rica, Dominica, Dominican Republic, Ecuador, El Salvador, Grenada, Guatemala, Haiti, Honduras, Jamaica, Mexico, Nicaragua, Panama, Paraguay, Peru, Suriname, Uruguay, and Venezuela. American Convention Signatories and Ratifications, supra note 234.

316 American Convention on Human Rights, supra note 315, arts. 41(f), 44. There are two individual complaints procedures in the OAS system. First, the complaint procedure under the American Declaration on the Rights and Duties of Man, American Declaration of the Rights and Duties of Man, Res. XXX, Int'l Conf. of Am. States, 9th Conf. (May 2, 1948), reprinted in Inter-American Court of Human Rights, OAS, Basic Documents Pertaining to Human Rights in the Inter-American System, at 15, O.A.S. Doc. OEA/Ser.L/V/I.4 rev. 12 (2007) [hereinafter American Declaration], impacts all OAS member states that are not parties to the American Convention. See Lea Shaver, The Inter-American Human Rights System: An Effective Institution for Regional Human Rights Protection?, 9 WASH. UNIV. GLoBAL STUD. L. REV. 639, 650 (2010). The decisions of the IACHR under the American Declaration are non-binding. See id.at 650, 654. The IACHR may not transfer complaints on violations of the American Declaration to the $\mathrm{IAC}$, as such complaints are decided and heard before the IACHR. Id. at 651 . The second complaints mechanism is applicable to parties to the American Convention. Id. at 650 . Under this complaints mechanism, individual complaints filed under the American Convention must be heard first in the IACHR and then the IACHR may send an individual's petition to the IAC for adjudication if no settlement has been reached after the petition has been reviewed by the IACHR. $I d$. at $652-54$. The IAC's jurisdiction may be exercised over states that recognize the jurisdiction of the IAC via ratifying the American Convention and issuing a separate statement acceding to the IAC's jurisdiction. Id at 650-52; see also Ariel Dulitzky, The Inter-American Human Rights System Fifty Years Later: Time for Changes, REV. QuÉBÉCOISE DROIT INT'L, Special Edition 2011, at 127, 134; The InterAmerican Human Rights System, Hum. RTS. Educ. Assoclates, http:/www.hrea.org/index.php?doc_id=413 (last visited Aug. 14, 2012). Ariel Dulitzky contends that the Inter-American system has been successful because of the OAS" "individual complaints mechanism, on-site visits, preparation and publication of reports, adoption of precautionary and provisional measures, friendly solutions, thematic reports, and jurisprudence on reparations ...." Dulitzky, supra, at 129 .

317 Dulitzky, supra note 316 , at 134.

$318 \mathrm{ld}$. 
While the African human rights system contains a mechanism through which certain complaints by individuals may be heard through the AU Human Rights Commission, the ADC does not reference an individual's ability to lodge complaints with the AU Human Rights Commission, the AU, or an appropriate African court. ${ }^{319}$ Perhaps, the lack of such a provision signals that the AU did not intend for individuals to have standing to file complaints before the AU Human Rights Commission or an appropriate African court regarding a member state's failure to comply with the provisions of the ADC. Nonetheless, the lack of such a reference in the ADC is not necessarily fatal, as individuals may be able to access the AU Human Rights Commission complaint mechanism to the extent that the democratic principles espoused in the ADC depend on a member state's respect for the human rights and democratic principles set forth in the African Charter. However, the existence of clawback clauses in the African Charter, along with the non-binding nature of the decisions of the AU Human Rights Commission, ${ }^{320}$ may frustrate the efforts of individuals who seek to hold their countries accountable for violations of the human rights and democratic principles set forth in the African Charter. Moreover, the ability of individuals to assert their own rights by bringing individual claims is arguably an important feature of a successful human rights regime. The $\mathrm{ADC}$ should be revised to establish the right of individuals and NGOs to bring complaints regarding violations of the ADC before the AU, the appropriate African court, and/or the AU Human Rights Commission.

\section{Workers'Rights}

The ODC recognizes the important role played by workers' rights and core labor standards in the promotion and strengthening of democracy. ${ }^{321}$ The ODC acknowledges the labor principles recognized in the ILO Declaration. ${ }^{322}$ The ILO Declaration requires states to respect and promote the following rights: freedom of association and the recognition of the right to collective bargaining; the elimination of forced or compulsory labor; the abolition of child labor; and

\footnotetext{
319 See African Charter, supra note 69, art. 56. For a detailed discussion of the AU Human Rights Commission's individual complaint mechanism, see Chidi Anselm Odinkalu, The Individual Complaints Procedures of the African Commission on Human and Peoples' Rights: A Preliminary Assessment, 8 TRANSNAT'L L. \& CONTEMP. PROBS. 359 (1998).

320 See supra note 78 and accompanying text

321 ODC, supra note 224, art. 10

$322 \mathrm{Id}$.
} 
the elimination of employment discrimination. ${ }^{323}$ In contrast, the ADC does not mention the ILO Declaration and does not specifically reference workers' rights and labor standards. Instead, the ADC contains a generic reference to a state's obligation to adopt and implement policies that "generate productive employment" 324 and requires member states to "eliminate all forms of discrimination...."325 One of the cornerstones of any modern successful democracy is the elimination of forced labor and child labor. Citizens that are gainfully employed are more likely to participate fully in elections and the democratic process in general and are more likely to hold their governments accountable for violations of human rights and democratic principles. ${ }^{326}$ Although the $\mathrm{AU}$ has adopted separate instruments which address workers' rights and forced labor, it is surprising that the $\mathrm{AU}$ elected not to reference such instruments or workers' rights in the ADC given the important role that such rights play in the democratic process. The ADC should be revised to recognize the principles established by the ILO Declaration and to emphasize workers' rights.

\section{Monitoring Elections}

Both the ODC and the ADC contain detailed provisions regarding election monitoring. For instance, both instruments allow member states to request election assistance to strengthen their electoral system. ${ }^{327}$ However, the two

323 Int'l Labour Org., ILO Declaration on Fundamental Principles, para. 2, Int'l Labour Conf., 86th Sess., (June 18, 1998).

324 ADC, supra note 1 , art. 40.

325 ADC, supra note 1, art. 8. It should be noted that the AU Assembly adopted the Declaration on Employment and Poverty Alleviation in Africa. Declaration on Employment and Poverty Alleviation in Africa, AU Assemb. Decl. 3 (III), A.U. Doc. EXT/ASSEMBLY/AU/3(III) (Sept. 8-9, 2004). This declaration references a number of the rights discussed in the International Labor Organization Convention; however, this declaration is not referenced in the $\mathrm{ADC}$. Id.; see also $\mathrm{ADC}$, supra note 1 , art. 40.

326 A 2010 study regarding the relationship between employment and political participation concluded that young unemployed individuals are less engaged in political activities. See Marco Giugni \& Jasmine Lorenzini, Employment Situation, Social Capital, and Political Participation: A Survey of Unemployed and Precarious Youth in Geneva 13 (Sept. 16-17, 2010) (unpublished working paper), available at http://www. younex.unige.ch/Products/Workingpapers/Employment_socialcapital_politicalparticipation.pdf. Similarly, a 1987 study found that individuals with less stress and greater job autonomy, social interaction, and income were more politically active. Shawn M. Burn \& Alison M. Konrad, Political Participation: A Matter of Community, Stress, Job Autonomy, and Contact by Political Organizaiions, 8 POL. PSYCHOL. 125, 136 (1987).

327 Compare ADC, supra note 1, art. 18(1) ("States Parties may request the Commission, through the [DEAU] . . . to provide advisory services or assistance for strengthening and developing their electoral institutions and processes."), with ODC, supra note 224, art. 17 ("When the government of a member state considers that its democratic political institutional process or its legitimate exercise of power is at risk, it may request assistance from the Secretary General or the Permanent Council for the strengthening and preservation of its democratic system."). 
charters differ with respect to the ability of the OAS and the AU to intervene in the affairs of a member state and dispatch electoral observer missions. The ODC provides that all electoral observer missions may be carried out only at the request of the member state concerned, and it requires the member state and the OAS to enter into an agreement establishing the scope and coverage of the electoral mission. ${ }^{328}$ Once an agreement has been made, the member state must cooperate with the observer mission and provide free access to information. ${ }^{329}$ The need for prior authorization from member states may potentially be abused, particularly by heads of state that would prefer zero international interference in the event they attempt to retain power by using undemocratic means. ${ }^{330}$ Further, requiring that an agreement be reached with the member state prior to sending an electoral mission could negatively impact the ability of the OAS to intervene promptly in political crises. This is in stark contrast to the provisions under the $\mathrm{ADC}$, which are broader in this area.

The $\mathrm{ADC}$ does not require the $\mathrm{AU}$ to obtain member state consent prior to sending exploratory pre-election missions or dispatching election observers. The ADC simply provides that the AU Commission "may at any time, in consultation with the State Party concerned, send special advisory missions to provide assistance to that State Party for strengthening its electoral institutions and processes. "331 The ADC does not require prior member state consent, but simply encourages member state consultations prior to dispatching advisory missions. ${ }^{332}$ The ADC also provides that prior to elections, ratifying member states must inform the Commission of the AU ("AU Commission") of all scheduled elections and the chairperson of the AU Commission is required to send an exploratory pre-election mission to each country to ensure that the political environment in a member state is conducive to the holding of free and transparent elections. ${ }^{333}$ The OAS has no such power under the ODC. ${ }^{334}$

\footnotetext{
328 ODC, supra note 224, art. 24 ("The electoral observation missions shall be carried out at the request of the member state concerned. To that end, the government of that state and the Secretary General shall enter into an agreement establishing the scope and coverage of the electoral mission in question.").

$329 \mathrm{Id}$.

330 However, there are some OAS member states that have freely consented to OAS intervention. For example, the governments of Ecuador and Nicaragua have authorized OAS intervention by invoking Article 18 of the ODC. Timothy D. Rudy, A Quick Look at the Inter-American Democratic Charter of the OAS: What Is It and Is It "Legal"?, 33 SYRACUSE J. INT'L L. \& COM. 237, 244 (2005) (citing OAS AG Dec. 43 (XXXVO/05), pmbl., O.A.S. Doc. OEA/Ser.P/XXXV-O.2 (June 7, 2005); OAS Permanent Council Res. 880 (1478/05), para. 3, O.A.S. Doc. OEA/Ser.G CP/RES. 880 (1478/05) (Apr. 22, 2005)).

331 ADC, supra note 1 , art. 18(2).

332 See id.

333 Id. arts. $19-20$.

334 See ODC, supra note 224.
} 
During elections, the $\mathrm{ADC}$ requires that member states extend invitations to the $\mathrm{AU}$ Commission for electoral observer missions and obligates member states to cooperate with such missions. ${ }^{335}$

At first glance the reference to the AU Commission's involvement in monitoring elections would appear to be a positive step, as the AU Commission is the secretariat of the AU and is responsible for the executive functions of the AU. ${ }^{336}$ However, the Elections Declaration specifically established a unit, the DEAU, which is responsible for monitoring elections in African countries. ${ }^{337}$ Surprisingly, the DEAU is only sparingly mentioned in the ADC. Article 18 of the ADC provides that state parties may request that the AU Commission, through the DEAU, provide advisory services to facilitate free and fair elections. ${ }^{338}$ Article 44 provides that the AU Commission should take measures necessary to ensure that the DEAU assists member states when needed. ${ }^{339}$ Article 18 and Article 44 of the ADC are the only sections where the DEAU is specifically referenced in the charter. Additionally, the ADC is silent on whether the electoral observer missions required by the ADC will be conducted under the auspices of the DEAU. ${ }^{340}$ Thus, outside of providing general assistance when a state party makes a request, the ADC is unclear regarding how involved the DEAU will be in observer missions that are dispatched prior to elections.

Rather than addressing the role of the DEAU in conducting electoral missions, the ADC provides that such missions must be conducted by appropriate experts drawn from national and continental institutions with due regard to "the principles of regional representation and gender equality." 341 The principle of regional representation has been incorporated into other conventions and declarations adopted by the $\mathrm{AU}$ with negative consequences. For instance, the AU PSC Protocol provides that members of the PSC will be appointed subject to the principle of equitable regional representation. ${ }^{342}$ However, it is likely that this principle has allowed African countries that fail

\footnotetext{
335 ADC, supra note 1, art 19.

336 Constitutive Act, supra note 84, art. 20(1); see also African Union, The Commission, http://www.au. int/en/commission (last visited September 12, 2012).

337 Elections Declaration, supra note 117, art. VI(d).

338 ADC, supra note 1 , art. 18

339 Id. art. $44(2)$.

340 See id. Article 19(1) of the ADC provides that "each State Party shall inform the [AU] Commission of scheduled elections and invite it to send an electoral observer mission." Id. art. 19(1).

341 Id. art. 21(2).

342 AU PSC Protocol, supra note 94, art. 5(2)
} 
to adhere to democratic principles to obtain positions on the PSC, the body responsible for promoting peace, security, human rights, and democracy in Africa. ${ }^{343}$ Therefore, in addition to articulating the role of the DEAU in electoral observer missions, and rather than relying on the principle of equitable regional representation, the ADC should provide that electoral observer missions will be conducted by leading experts and national electoral bodies from African countries that rank highly on international democracy indices. Additionally, the recent military coup in Egypt illustrates that although elections are an integral component of strong liberal democracies, free and fair elections, without more, will not guarantee successive democratic changes in government. The $\mathrm{AU}$ must ensure that democratically elected governments continue to respect the rule of law and the doctrine of separation of powers.

\section{General Enforcement Mechanism}

When compared to the ODC, the ADC is notable in that it specifically contains an enforcement procedure that impacts ratifying member states that fail to comply with the general principles set forth in the ADC. ${ }^{344}$ In contrast, with the exception of the ability of the OAS to suspend member states from participation in the $\mathrm{OAS}^{345}$ the ODC does not contain a provision that addresses the consequences that will be faced by a member state that fails to adhere to the principles set forth in the ODC. The ADC not only allows the AU to suspend member states from the $A U,{ }^{346}$ but pursuant to Article 46 , the Assembly and the PSC have the power to determine the appropriate measures that will be imposed on non-compliant member states in accordance with the Constitutive Act and the AU PSC Protocol. ${ }^{347}$ Perhaps the failure of the ODC to include additional enforcement provisions is due in part to its nature. The ODC has been referred to as "soft law" and is in fact a non-binding resolution of the OAS. ${ }^{348}$ As a result, member states of the OAS are arguably not obligated to adhere to the provisions of the ODC. In contrast, once the ADC has been executed and ratified by a member state, the charter becomes a binding instrument and the AU then has the ability to enforce the ADC and

343 See Elvy, supra note 72 , at 137-138 (arguing against the use of the principle of equitable regional representation in the selection of PSC members who violate human rights and democratic principles such as Zimbabwe, Libya, and Equatorial Guinea); see also AU PSC Protocol, supra note 94, art. 3.

344 ADC, supra note 1, arts. 44, 46.

345 ODC, supra note 224 , art. 21.

346 ADC, supra note 1, art. 25(1).

347 Id. art. 46.

348 Rudy, supra note 330 , at 240. 
hold ratifying member states accountable for their non-compliance. ${ }^{349}$ Despite the non-binding nature of the ODC, it established a consensus on the importance of democratic principles and norms in the Americas, and at the very least, the ODC represents a non-binding commitment by OAS member states to promote democracy in their respective countries.

While Article 46 of the ADC provides that member states may be subject to disciplinary actions from the Assembly and PSC for failing to comply with the general principles of the ADC, the charter fails to describe the specific disciplinary measures that can be taken by the Assembly and the PSC. ${ }^{350}$ If there is no unconstitutional change of government, what happens if a state simply fails to fulfill its obligations under the ADC? The ADC simply states that the Assembly and the PSC have the power to decide appropriate disciplinary measures when a state party violates the ADC. ${ }^{351}$ However, to fully promote democracy, the AU must clearly communicate to member states the specific disciplinary measures that will be imposed in the event that a state fails to satisfy any obligation under the ADC.

An argument can be made that Article 46 of the ADC does not need to specifically reference a list of disciplinary measures, as it references the power of the Assembly to determine the appropriate disciplinary measures in accordance with the Constitutive Act and the AU PSC Protocol. However, according to the institutionalist perspective on state compliance with international law, non-compliance often occurs when international norms and principles are ambiguous. ${ }^{352}$ Therefore, there is value in clearly articulating to member states the consequences that member states will face if they fail to adhere to the principles contained in the ADC, rather than simply referring member states back to ambiguous provisions in other regional instruments such as the Constitutive Act. ${ }^{353}$ Moreover, in Article 25 of the ADC, the AU observed that there was a need to elaborate on the consequences, such as punitive economic measures, that member states would face in the event of an

349 Id.

350 ADC, supra note 1 , art. 46.

351 ld.

352 Sonia Cardenas, Norm Collision: Explaining the Effects of International Human Rights Pressure on State Behavior, 6 INT'L STUD. REV. 213, 219-220 (2004)

353 The disciplinary provisions of the Constitutive Act are ambiguous. Article 23 of the Constitutive Act only references the ability of the Assembly to sanction member states for their failure to comply with the decisions and policies of the Assembly. Constitutive Act, supra note 84, art. 23. However, the term "policies" is not defined in the Constitutive Act. $I d$. For a detailed discussion on the ambiguities contained in the Constitutive Act, see Elvy, supra note 72 , at 87-94. 
unconstitutional change of government. ${ }^{354}$ There is no reason why a similar provision should not have been included in Article 46. The promotion of democracy cannot simply be about preventing unconstitutional changes of government. To fully promote democracy the AU must clearly communicate to ratifying member states that they will face extensive consequences not only in the event of an unconstitutional change of government, but also in the event that they fail to satisfy any of their obligations under the ADC, including, but not limited to, a member state's obligation to provide access and information to electoral observer missions, eliminate gender inequality, and educate its citizens on the provisions of the ADC.

\section{State Reporting}

While the ODC is silent with respect to a state's obligation to submit periodic reports regarding compliance with the provisions of the charter, ${ }^{355}$ the ADC specifically addresses this issue. Article 49 of the ADC requires ratifying member states to submit biennial reports on the measures taken to comply with the objectives of the charter. ${ }^{356}$ States that fail to submit these biennial reports would be subject to disciplinary action under Article 46 of the ADC, which, as previously mentioned, simply resorts to the vague disciplinary measures under the Constitutive Act and the AU PSC Protocol. ${ }^{357}$ Article 62 of the African Charter contains a similar requirement for biennial reports. ${ }^{358}$ While it is admirable that the ADC obligates states to submit reports on their compliance status, as discussed in Part II.D of this Article, the AU continues to struggle with the failure of member states to submit timely reports under the African Charter. ${ }^{359}$ Moreover, the disciplinary measures established in the Constitutive Act and African Charter to address such failures as currently applied by the AU, do not seem to have an impact on state compliance. If member states are struggling with their ability to meet state reporting requirements under the African Charter, it is unlikely that member states will be able to fulfill the

\footnotetext{
354 ADC, supra note 1 , art. 25

355 Although the ODC does not establish a state reporting mechanism, Article 26 of the ODC provides that the OAS will consult with member states on an ongoing basis to promote a democratic culture in the hemisphere. ODC, supra note 224, art. 26. Additionally, under the Additional Protocol to the American Convention, ratifying-member states are required to submit periodic state reports to the OAS. Additional Protocol to the American Convention on Human Rights in the Area of Economic, Social and Cultural Rights "Protocol of San Salvador" art. 19, Nov. 17, 1988, O.A.S.T.S. No. 69, 28 I.L.M. 161.

356 ADC, supra note 1 , art. 49.

357 Id. art. 46.

358 Compare African Charter, supra note 69, art. 62, with ADC, supra note 1, art. 49.

359 See supra Part II.D.
} 
reporting requirements under the $\mathrm{ADC}$. With Article 49 of the $\mathrm{ADC}$, the $\mathrm{AU}$ continues to create state reporting requirements without specifically addressing the failure of such requirements under other legal instruments such as the African Charter and the Corruption Convention.

Of the fifteen member states that have ratified the ADC only Nigeria is up to date on its state reports under the African Charter. ${ }^{360}$ The following member states that have ratified the ADC are behind on their state reporting obligations under the African Charter: Burkina Faso, Cameroon and Rwanda are behind by one report; Ethiopia is behind by two reports; South $A$ frica is behind by three reports; Mauritania and Niger are behind by four reports; Lesotho is behind by six reports; Ghana and Chad are behind by seven reports; and Guinea-Bissau and Sierra Leone have never submitted a report. ${ }^{361}$ One potential solution to this problem is to permit member states to incorporate their state reports under the ADC into their required state reports under the African Charter. After all, the African Charter does contain a number of provisions that require member states to respect and promote democratic principles. Moreover, state reports under both the African Charter and the ADC are due biennially. ${ }^{362}$ As such, incorporating both state reports into one document may be more convenient for member states; thereby making it more likely that states will comply with their reporting obligations.

\section{B. The OAS Democratic Charter in Action: Lessons for the AU}

The preceding review of the ODC and the ADC reveals the strengths and weaknesses of both regional instruments and identifies a number of areas in which the ADC may be strengthened. As referenced in the Introduction of this Article, the OAS and the AU are part of an inter-regional initiative to promote democracy in the Americas and Africa. ${ }^{363}$ It has been over a decade since the adoption of the ODC. ${ }^{364}$ In contrast, the ADC recently entered into force on February 15, 2012..$^{365}$ Thus, analyzing the OAS' application of the ODC may provide guidance to the AU on how to effectively implement the ADC. Since the adoption of the ODC on September 11, 2001, a number of OAS member states, including Venezuela, Honduras, Nicaragua, and Ecuador, have faced

\footnotetext{
360 State Reports and Concluding Observations, supra note 165.

361 Id.

362 ADC, supra note 1 , art. 49

363 See supra Introduction.

364 See supra note 224.

365 Ratification Status of the ADC, supra note 2
} 
threats to their democratic process. The OAS' attempts to resolve these crises through use of the ODC indicate that the establishment of a viable liberal democracy requires much more than the adoption of a regional charter on democracy.

\section{Venezuela}

Opposition to the implementation of several governmental reforms led to the 2002 political crisis in Venezuela. ${ }^{366}$ Former President Hugo Chávez Frías was dismissed by the country's minister of defense and Pedro Carmona Estanga, was appointed to head a new transitional government. ${ }^{367}$ Estanga abolished the Constitution and dissolved the branches of government. ${ }^{368}$ Aware of the crisis, the OAS applied Article IV of the ODC for the first time, which required condemnation of "the alteration of constitutional order." "369 For the most part, however, the resolution of the Venezuelan crisis did not occur because of the OAS' efforts. Estanga had lost the backing of his early supporters and his attempted coup d'état fell apart internally. ${ }^{370}$ Moreover, despite the OAS' involvement in Venezuela, Chávez had already returned to power before OAS members were able to convene a special meeting of the General Assembly in order to send a mission to observe the crisis in Venezuela. ${ }^{371}$ The OAS eventually sent an electoral observation mission to

366 Org. of Am. States, Tenth Anniversary of the Inter-American Democratic Charter: A Hemispheric Commitment to Democracy 28 (2011) [hereinafter Hemispheric Commitment]. Upon President Chavez's election to office in 1998 "he implemented a new constitution and created various social programmes to exploit the country's vast oil wealth in an effort to benefit the poor through education, health and land reform, all of which provoked the ire of the old corporate and political elite, who had seen their political power deteriorate." Jonathon David, Venezuela-The Coup of 2002, PASSing Nightmare (Apr. 11, 2012), http//passingnightmare.co.uk/2012/04/venezuela-the-coup-of-2002/. This deterioration of political power allegedly led to the 2002 military coup. See id.

367 HEMISPHERIC COMMITMENT, supra note 366 , at 28.

$368 \mathrm{ld}$.

369 Id. (quoting OAS Permanent Council Res. 811 (1352/02), para. 1, O.A.S. Doc. OEA/Ser.G CP/RES/811 (1352/02) (Apr. 13, 2002)).

370 Craig Arceneaux \& David Pion-Berlin, Issues, Threats, and Institutions: Explaining OAS Responses to Democratic Dilemmas in Latin America, LATIN AM. POL. \& SOC'Y, July 2007, at 1, 14 ("The OAS acted swiftly, but the coup fell apart from internal pressures, as Carmona quickly alienated his supporters."); see also HEMISPHERIC COMMITMENT, supra note 366 , at 28.

371 William Bickford, The Inter-American Democratic Charter: A Rush to Judgment, GATEWAY AM. POL. DESK BLog (Jan. 1, 2012), http:/gatewaytopolitics.blogspot.com/2012/01/inter-american-democratic-charterrush.html. At the OAS Permanent Council Meeting, the OAS decided to dispatch a fact-finding mission to resolve the crisis. HeMISPHERIC COMMITMENT, supra note 366, at 28. The special session of the General Assembly which met after the coup was thwarted did not adopt sanctions. Lagos \& Rudy, supra note 225, at 296. The General Assembly of the OAS requested that the restored government "[take] into account the 
Venezuela two years later to observe a referendum to recall Chávez from office. ${ }^{372}$ Chávez subsequently "placed limits on OAS electoral observer missions, disputed [the OAS'] findings, and, in general, [took] an antagonistic stance [toward OAS intervention]. ${ }^{, 373}$

The crisis in Venezuela indicated that the OAS decision-making process is "prone to some considerable stalling, if not immobilization,",374 particularly in cases where member states have differing opinions. Although the ADC, unlike the ODC, does not require member state consent prior to the AU dispatching an electoral observer mission, ${ }^{375}$ the $\mathrm{ADC}$ requires member states to fully cooperate with electoral observer missions, which includes providing them "free access to information, non-interference, [and] freedom of movement...., 376 It is unlikely that an electoral observer mission will be successful if the affected member state does not cooperate with the mission. Therefore, the Venezuelan crisis should indicate to the AU that ratifyingmember countries may resist the ability of the AU to dispatch electoral observer missions in accordance with Articles 19 and 20 of the ADC and the AU must be ready to utilize Articles 25 and 46 of the ADC to sanction noncompliant states. If the $\mathrm{AU}$ is reluctant to utilize the enforcement measures under the ADC, the AU may face a situation similar to that in Venezuela, where President Chávez placed limitations on electoral observer missions without consequence.

\section{Honduras}

In June 2009, democratically elected President Jose Manuel Zelaya attempted to hold a referendum to rewrite the Honduran constitution. ${ }^{377}$ Many have argued that the goal of the referendum was to remove Honduras' oneterm-presidential limit, which would have permitted Zelaya's re-election. ${ }^{378}$ In

\footnotetext{
essential elements of representative democracy set forth in Articles 3 and 4 of the [OAS] Democratic Charter." OAS A.G. Res. 1 (XXXIX-E/02), para. 3, O.A.S. Doc. OEA/Ser.P AG/RES. 1 (XXIX-E/02) (Apr. 18, 2002).

372 HEMISPHERIC COMMTTMENT, supra note 366, at 29.

373 Bickford, supra note 371; see also Andres Oppenheimer, Op-Ed., Chávez's 'Monitors' Are Really Electoral Tourists, Miamı Herald, Aug. 11,2004, at 13A.

374 Andrew F. Cooper \& Thomas Legler, The OAS Democratic Solidarity Paradigm: Questions of Collective and National Leadership, LATIN AM. POL. \& SOC'Y, Apr. 2011 , at 103, 112.

375 Compare ADC, supra note 1, arts. 18-20, with ODC, supra note 224, arts. 23-24.

376 See ADC, supra note 1, art. 19.

377 Noah Feldman, David Landau \& Brian Sheppard, Fixing Honduras, L.A. TMES, June 7, 2011, at Al1

378 Q\&A: Political Crisis in Honduras, BBC NEws (Jan. 27, 2010), http://news.bbc.co.uk/2/hi/americas/ 8124154.stm. Others have argued that President Zelaya did not propose a referendum which would be conducted on a ballot, but a survey that was being done for research purposes that would be carried out by the
} 
response, the Honduran Supreme Court held that such a referendum was unconstitutional. $^{379}$ Zelaya ignored the Supreme Court's holding and insisted on conducting the referendum without the aid of the Honduran armed forces ${ }^{380}$ in violation of the Honduran constitution, which required the armed forces to provide logistical support to the National Elections Tribunal during all elections. ${ }^{381}$ As a result, the Honduran Supreme Court ordered the armed forces to detain Zelaya and bring him before the Supreme Court for arraignment; however, Zelaya was sent into exile by the armed forces. ${ }^{382} \mathrm{~A}$ majority of the Honduran Congress voted to support Zelaya's removal from power, ${ }^{383}$ and Roberto Micheletti was appointed as interim president by the Honduran Congress. ${ }^{384}$

The OAS labeled the political crisis a military coup d'état and demanded President Zelaya's immediate and safe return without acknowledging the Honduran Supreme Court's holding that Zelaya's actions were unconstitutional. ${ }^{385}$ The General Assembly of the OAS adopted a resolution instructing the Secretary General to engage in diplomatic initiatives aimed at restoring democracy and reinstating Zelaya to power pursuant to Article 20 of the ODC. ${ }^{386}$ The resolution also provided that in the event that diplomatic initiatives were unsuccessful within 72 hours, the Special Session of the General Assembly would invoke Article 21 of the ODC to suspend Honduras from participation in the OAS. ${ }^{387}$ Diplomatic initiatives eventually failed and

National Institute of Statistics, which was not a legally authorized electoral body. See Jules Siegel, Honduras Supreme Court: It Was "Common Knowledge" That Zelaya Was No Longer President, Huffington Post (July 13, 2009, 10:49 AM), http://www.huffingtonpost.com/jules-siegel/honduras-supreme-court-it_b_230621. html.

379 Bickford, supra note 371 .

380 Id. ("Honduras' Congress, Supreme Court and Attorney General ruled that such a referendum would not be legal. . . Zelaya fired his commander and declared that he and his followers would take charge of the ballots.")

381 Constitución Politica de la Republica de Honduras, ch. X, art. 272, La Gaceta, Diario OFICIAL [L.G.] No. 23,612, 20 January 1982, as amended by Decreto No. 36, L.G. May 4, 2005.

382 Bickford, supra note 371; see also Siegel, supra note 378.

383 Roberto Micheletti, The Path Forward for Honduras, WALL ST. J., July 27, 2009, at A15; see also Peter J. Meyer, Cong. Research Serv., R41064, Honduran Political Crisis, June 2009-January 2010, at $4(2010)$.

384 Bickford, supra note 371 .

385 HEMISPHERIC COMMITMENT, supra note 366, at 32; see also OAS Political Missions Map, OAS PEACE FUND, http:/www oas.org/sap/peacefund/PeaceMissions/PoliticalMissionsMap.html (last visited Aug. 15, 2012).

386 OAS A.G. Res. 1 (XXXVII-E/09), para. 4, O.A.S. Doc. AG/RES. 1 (XXXVII-E/09) rev. 1 (July 2, 2009); see also HEMISPHERIC COMMTMENT, supra note 366 , at 32.

387 OAS A.G. Res. 1 (XXXVII-E/09), supra note 386, para. 4; see also HEMISPHERIC COMMITMENT, supra note 366 , at 32 . 
Honduras was suspended from the OAS. ${ }^{388}$ The OAS then continued to work with other international actors, including the former Costa Rican President Oscar Arias, to facilitate resolution of the crisis in Honduras which culminated in the execution of the Tegucigalpa/San José Accord, an agreement that contemplated the establishment of a national unity and reconciliation government. ${ }^{389}$ Eventually, on January 27, 2010, Porfirio Lobo Sosa was sworn in as the new president of Honduras, bringing an end to Roberto Micheletti's de facto government. ${ }^{390}$ Zelaya was allowed to return to Honduras $^{391}$ and was appointed as a deputy of the Central American Parliament representing Honduras. ${ }^{392}$

The situation in Honduras posed an interesting question for the OAS: how to handle a crisis that was created by a democratically elected president who allegedly attempted to retain power through undemocratic means in violation of the state constitution. The OAS' response was simply to quickly label the crisis as a military coup and an unconstitutional interruption of the democratic order under Article 19 of the ODC. ${ }^{393}$ Although Zelaya was the democratically elected president, the Supreme Court of Honduras had ruled that his actions were unconstitutional and had ordered his detainment. The military eventually placed Zelaya in exile without the Supreme Court's approval; however, this still does not negate the fact that the Supreme Court had deemed his actions unconstitutional and the Honduran Congress had voted to remove him from power. Thus, it is clear that the situation in Honduras was not a regular coup d'état. By immediately demanding Zelaya's return to power and labeling the crisis a military coup, the OAS mistakenly conveyed the message that it supported Zelaya's alleged attempt to retain power through unconstitutional means. Despite concluding that Zelaya's removal from power was unconstitutional, the Honduran Truth and Reconciliation Commission, which

\footnotetext{
388 OAS A.G. Res. 2 (XXXVII-E/09), para. 1, O.A.S. Doc. AG/RES. 2 (XXXVII-E/09) rev. 1 (July 16, 2009).

389 Guaymuras Dialogue-Tegucigalpa/San José Agreement for National Reconciliation and Strengthening the Democracy of Honduras, Oct. 30, 2009, O.A.S. Doc. CP/INF.5928/09 [hereinafter Tegucigalpa-San José Accord]; HemisPHERIC Commitment, supra note 366, at 32.

390 New Honduran President Takes Office, CNN (Jan. 27, 2010), http:/articles.cnn.com/2010-01-27/ world/honduras.president_1_new-honduran-president-political-crisis-porfirio-pepe-lobo-sosa?_s=PM: WORLD.

391 Ousted Leader Manuel Zelaya To Return to Honduras, GUARDIAN (May 23, 2011), http://www. guardian.co.uk/world/2011/may/23/ousted-manuel-zelaya-return-honduras.

392 Press Release, OAS, OAS Secretary General Pleased with Swearing in of President Zelaya to PARLACEN, OAS Press Release No. E-338/10 (Sept. 20, 2010), http:/www.oas.org/en/media_center/press_ release asp?sCodigo $=\mathrm{E}-338 / 10$.

393 OAS A.G. Res. 1 (XXXVII-E/09), supra note 386, pmbl; see also ODC, supra note 224, art. 19.
} 
was established as part of the Tegucigalpa-San José Accord, concluded in 2011 that Zelaya broke the law when he refused to follow the Supreme Court ruling that the referendum was unconstitutional. ${ }^{394}$

The lesson to be learned from the OAS' handling of the Honduran crisis is that in seeking to use a democratic charter, a regional human rights body may inadvertently appear to support the use of undemocratic measures, if the human rights body fails to adopt a more individualized approach when responding to a political crisis that involves a democratically elected president that has used undemocratic means to perpetuate himself in power. Rather than simply labeling such a crisis as a coup d'état, and thereby inadvertently expressing support for the undemocratic measures used by the democratically elected president, the OAS should have expressed its opposition to the use of undemocratic measures and should have also expressly acknowledged in its resolutions the decision by the Honduran Supreme Court condemning the president's undemocratic actions. Therefore, a more individualized approach might involve a combination of the following: evaluating the laws of the applicable country to determine the lawfulness of the actions of the democratically elected leader and the individuals who removed him or her from power ("Leader's Opponents"); considering the jurisprudence of the country's judiciary and legal interpretation of the applicable laws, for example, as previously noted, the Supreme Court of Honduras had ruled that the president's actions were unlawful ${ }^{395}$ considering the actions taken by other governmental institutions, for instance, as previously noted, Honduras' congress had voted to remove the president from power; and evaluating the underlying reasons for the actions of the democratically elected leader and the Leader's Opponents, for example, if the Leader's Opponents acted unlawfully by removing the president from power, but the president was in fact utilizing undemocratic measures.

394 Honduras Truth Commission Rules Zelaya Removal Was Coup, BBC News (July 7, 2011), http:/www.bbc.co.uk/news/world-latin-america-14072148; accord Honduras: Freedom in the World 2012, FREEDOM HOUSE, http://www.freedomhouse.org/report/freedom-world/2012/honduras (last visited Mar. 20, 2013) ("The Truth and Reconciliation Commission ... [found] that Zelaya"s removal from office constituted an illegal coup .... The commission also stated that Zelaya shared blame for instigating the crisis with his push for a referendum, and that the international community, and the OAS in particular, failed to stop or reverse the coup."); see also Tegucigalpa-San José Accord, supra note 389, art. 6; Truth Commission: Honduras 2010, U.S. INST. PEACE (Feb. 2012), http://www.usip.org/publications/truth-commission-honduras2010.

395 See Bickford, supra note 371 


\section{Nicaragua}

In 2005, President Enrique Bolaños requested that the OAS intervene to facilitate discussions between the executive branch and major political parties regarding a proposed constitutional reform that would increase the power of the legislative branch. ${ }^{396}$ The OAS facilitated discussions between the government and rival political parties, which led to the adoption of the Framework Law on Stability and Governance and to the suspension of the adoption of the proposed constitutional law reform. ${ }^{397}$ However, the 2006 and 2008 municipal elections in Nicaragua were widely criticized as fraudulent, ${ }^{398}$ and in 2011, President Daniel Ortega was elected after the Nicaraguan Supreme Court lifted a ban on consecutive presidential terms. ${ }^{399}$

The OAS' response to the continued election problems in Nicaragua has been heavily criticized and has been described as neither "swift nor substantive." ${ }^{400}$ Further, the OAS' recent report on election fraud in Nicaragua has been criticized as "lack[ing] any concrete solutions ... [and] fail[ing] to mention the real cause and root of the problem: that Daniel Ortega violated the Nicaraguan constitution, which forbade his re-election."401 Despite the OAS' intervention in Nicaragua in 2005, Nicaragua continues to be plagued by

396 Hemispheric COMmitment, supra note 366 , at 29. Ignoring the objections of the legislative branch, President Bolanos refused to publish the proposed constitutional reform, which ultimately prevented the reform from entering into force. Id. The constitutional reforms sought to limit the president's powers by providing that the National Assembly of Nicaragua could overturn a presidential veto by a simple majority rather than a two-thirds vote, and by creating new institutions that would monitor the actions of the executive branch in connection with public services, property, and social security. MANUEL OROZCO, OF POLITICS AND DEMOCRACY IN NICARAGUA IN THE XXIST CENTURY 8 (2006), available at http:/www.thedialogue.org/ PublicationFiles/Politics $\% 20$ and $\% 20$ democracy $\% 20 \mathrm{in} \% 20$ Nicaragua.pdf. The proposed constitutional reforms also provided that presidential appointments of ministers, senior diplomats, and heads of public companies would be subject to confirmation by the National Assembly of Nicaragua. Id.

397 Hemispheric COMmitment, supra note 366, at 29; see also OAS A.G. Dec. 43, O.A.S. Doc. AG/DEC. 43 (XXXV-O/05) (June 7, 2005) (declaring the need to send to Nicaragua "a mission headed by the OAS Secretary General, that helps to establish a broad national dialogue, with a view to finding democratic solutions to the serious problems that exist ...").

398 Bickford, supra note 371; see also Press Release, U.S. State Dep't, Irregularities in Nicaraguan Municipal Elections, State Dep't Press Release 2008/942 (Nov. 10, 2008), available at http://2001-2009. state. gov/r/pa/prs/ps/2008/nov/111736.htm.

399 Miguel Angel Gutierrez \& Ivan Castro, Nicaragua's Ortega Wins Landslide Election, ReUTERs, Nov. 7, 2001, available at http://www.reuters.com/article/2011/11/07/us-nicaragua-election-idUSTRE7A50D32011 1107.

400 See Bickford, supra note 371

401 Press Release, House Chairman of the Comm. on Foreign Affairs Rep. Ileana Ros-Lehtinen, OAS Report on Nicaraguan Elections Lacks Concrete Solutions, Fails to Address Ortega Violations, Ros-Lehtinen Says (Jan. 27, 2012), http://archives.republicans.foreignaffairs.house.gov/news/story/?2181. 
election fraud. ${ }^{402}$ The OAS' lackluster response in Nicaragua indicates that regional human rights organizations, such as the $A U$, that intend to promote democracy through the use of a democratic charter must continue to actively monitor elections even after a potential crisis has been averted. Such organizations also must propose concrete solutions to aid member states that continue to be plagued by election abnormalities, otherwise, these countries will continue to face a "steady erosion of [their] democratic institutions and practices." 403

\section{Ecuador}

In December 2004, the Ecuadorian Congress removed most of the Supreme Court justices and voted to replace twenty-seven of the thirty-one justices with their own political allies. ${ }^{404}$ In response, President Lucio Gutiérrez claimed that the court was loyal to his political opponents, who had previously attempted but failed to hold impeachment hearings against him and he engaged in "an unconstitutional power play to pack all of the country's judicial institutions with political allies." ${ }^{405}$ Gutiérrez allegedly "manipulated his party's modest advantage in the legislature - 52 of 100 seats - to replace five of seven members of the Supreme Electoral Council and eight of nine members of the Constitutional Tribunal, which is the highest court in the land dealing with constitutional issues." Gutiérrez had abandoned his office and Vice President Alfredo Palacio was appointed as his successor. ${ }^{407}$ It has been argued that the actions of the Ecuadorian Congress were authorized under Article 167 of the Constitution of Ecuador. $^{408}$

402 See Press Release, U.S. State Dep't, Response to Municipal Elections in Nicaraguan, State Dep't Press Release 2012/1737 (Nov. 5, 2012), available at http:/www.state.gov/r/pa/prs/ps/2012/11/200169.htm.

403 Bickford, supra note 371

404 Ecuador Faces Institutional Crisis, TranSPARENCY InT'L (Apr. 6, 2005), http://archive transparency. org/news_room/in_focus/2005/crisis_ecuador1; see also, Ecuador: Removal of Judges Undermines Judicial Independence, Hum. RTS. WATCH (May 11, 2007), http://www.hrw.org/news/2007/05/10/ecuador-removaljudges-undermines-judicial-independence.

405 Ecuador Faces Institutional Crisis, supra note 404; see also Ecuador: Freedom in the World 2009, FrEEDOM HOUSE, http:/www. freedomhouse.org/report/freedom-world/2009/ecuador (last visited Mar. 20, 2013) ("Gutierrez dismissed the Supreme Court for political bias, replacing the panel with loyal judges who granted immunity to several exiled politicians facing corruption accusations.").

406 Ecuador Faces Institutional Crisis, supra note 404.

407 Bickford, supra note 371; see also Ecuador: Freedom in the World 2009, supra note 405.

408 Hemispheric COMmitment, supra note 366, at 29-30; see also CONSTITUCión POLitica DE LA REPÚBLICA DE ECUADOR DE 1998 , tit. VII, ch. 1, art. 167(5). 
The OAS used the ODC and a special mission was sent to Ecuador, which helped to facilitate discussions that allowed for the election of supreme court justices. ${ }^{409}$ However, the OAS was criticized for labeling Gutiérrez's removal as a coup d'etat ${ }^{410}$ and for failing to condemn Gutiérez's unconstitutional actions. ${ }^{411}$ Further, by the time the OAS mission arrived Ecuador had been without a functioning Supreme Court for at least one year. ${ }^{412}$ As was the case in Honduras, the lesson to be learned in the application of charters aimed at promoting democracy is that the OAS' response to the crisis in Ecuador signals that a more nuanced approach is needed when labeling coup d'états. Gutiérrez's removal was not necessarily a coup because the 2005 Constitution of Ecuador may have given the Ecuadorian Congress the power to remove the president based on his allegedly unconstitutional actions. ${ }^{413}$ Further, the OAS should have condemned the actions of Gutiérrez and perhaps the actions of the Ecuadorian Congress in removing the supreme court justices, which violated the principle of judicial independence. Although the 2005 crisis was resolved, the OAS failed to address the root causes of the dispute as a similar problem arose in 2007 when the Ecuadorian Congress voted to remove all nine judges of Ecuador's Constitutional Court in violation of Ecuadorian law after a majority of the members of congress disagreed with the court's ruling. ${ }^{414}$ The Ecuadorian Congress and the executive branch of the Ecuadorian government must learn to value and respect the principle of judicial independence. To truly promote democracy in a country, the root causes of democratic instability must be addressed in order to ensure that similar problems do not continue to emerge.

\section{CONCLUSION}

The ADC reflects the AU's most recent efforts to promote democracy in Africa. The ADC has the potential to achieve this goal. However, the foregoing analysis has indicated that there are a few areas in which the ADC may be strengthened. The ADC should be revised to establish democracy as a legal

\footnotetext{
409 OAS C.P. Res. 880 (1478/05), para. 3, O.A.S. Doc. CP/RES. 880 (1478/05) (Apr. 22, 2005); HEMISPHERIC COMMLTMENT, supra note 366, at 29; see also OAS Political Missions Map, supra note 385.

410 Bickford, supra note 371.

411 See Toni Solo, The OAS and Nicaragua: The Very Model of a Modern Intervention, DISSIDENT VOICE (June 14, 2005), http://dissidentvoice.org/June05/solo0614.htm

412 HEMTSPHFRIC COMMTTMENT, supra note 366 , at 29.

413 Lawmakers Remove Ecuador's President, Fox NEws (Apr. 20, 2008), http://www.foxnews.com/story/ $0,2933,154069,00 . \mathrm{html}$

414 Ecuador: Removal of Judges Undermines Judicial Independence, supra note 404.
} 
right. Additionally, in the event of an unconstitutional change of government, the ADC conditions the suspension of member state benefits on the failure of diplomatic initiatives. ${ }^{415}$ This provision should be removed, as it arguably requires the $\mathrm{AU}$ to first initiate diplomatic efforts to resolve political and humanitarian crises, and then adopt a wait-and-see approach to determine if such efforts have failed, prior to suspending membership in the AU. ${ }^{416}$ Moreover, the ADC fails to provide guidance to member states on appropriate term limits. ${ }^{417}$ While term limits vary in democratic countries, African presidents have a long history of amending legal instruments to extend their time in power. ${ }^{418}$ The constitutions of many African countries, such as Cameroon, Chad, and Uganda, have been amended to either eliminate or extend presidential term limits, which has arguably contributed to the dearth of liberal democracies in AU member states. ${ }^{419}$ Therefore, the AU should provide guidance to member states on establishing appropriate presidential term limits. The ADC should also authorize sanctions where subversive tactics harm the democratic process, but do not rise to the level of an unconstitutional change of government and provide guidance on the level of proof that is necessary to demonstrate that a member state instigated an unconstitutional change of government. The ADC also fails to provide guidance on whether individuals can lodge complaints with the AU Human Rights Commission or an appropriate African court regarding a state's non-compliance with the ADC. This lack of guidance should be remedied. ${ }^{420}$ Additionally, the ADC should specify the chargeable offenses that may be imposed against the perpetrators of an unconstitutional change of government and which African court has jurisdiction to hear such cases.

The $\mathrm{ADC}$ requires member states to submit biennial reports regarding compliance with the charter. ${ }^{421}$ However, member states have been unable to satisfy their reporting obligations under earlier instruments and the AU has not effectively addressed member state non-compliance with these reporting requirements. ${ }^{422}$ The $\mathrm{AU}$ must effectively address member states' unwillingness to provide state reports and the ADC should be revised to permit

\footnotetext{
415 See supra Part III.A.2.b.

416 See ADC, supra note 1, art. 25

417 See supra Part III.A.2.a

418 See supra Part III.A.2.a.

419 See supra notes 9-11 and accompanying text

420 See supra Part III.A.4.

421 See supra Part III.A.8

422 See supra Part III.A.8.
} 
member states to combine the required ADC state reports with the state reports that must be made under other $\mathrm{AU}$ instruments.

Despite the fact that the $\triangle D C$ is lacking in some areas, the adoption and recent entry into force of the ADC signals that the AU and a few of its member states remain committed to the promotion of liberal democracies in Africa. The $\mathrm{ADC}$ is quite expansive when compared to the ODC and the prior instruments adopted by the AU to promote democracy. Unlike the ADC, the ODC does not define the events that constitute an unconstitutional change of government. ${ }^{423}$ The ADC not only defines an unconstitutional change of government, but in contrast to the Lomé Declaration, the ADC also includes in the definition of unconstitutional changes of government any change to the legal instruments of a country which may interrupt the democratic form of government. ${ }^{424}$ The $\mathrm{ADC}$ also authorizes the AU to sanction not only recalcitrant states, but also individual perpetrators of an unconstitutional change of government. ${ }^{425}$

The ADC is notable in that it acknowledges that it is not a stand-alone document. The ADC does this by recognizing and incorporating a number of the AU's prior instruments, which were adopted to promote democracy in Africa, but did so in a piecemeal manner. For example, the ADC provides that one of the goals of the charter is to eliminate corruption in Africa by facilitating compliance with the Corruption Convention. ${ }^{426}$ The ADC requires ratifying states to reaffirm the principles set forth in the Elections Declaration and promote free and fair elections in their respective countries. ${ }^{427}$ Liberal democracies emphasize a representative form of government "chosen through competitive elections ....,"428 The numerous provisions set forth in the ADC, which require free and fair elections in African member states and which authorize electoral observer missions, evidence the AU's support for the adoption of liberal democracies. ${ }^{429}$ Moreover, the ADC is the first binding legal instrument adopted by member states of the AU that seeks to address and promote all of the elements necessary for the establishment of liberal democracies. ${ }^{430}$ Previous attempts by the $A U$ to promote democracy involved the piecemeal adoption of individual regional instruments to address specific

\footnotetext{
423 See supra Part III.A.2.

424 See supra Part III.A.2

425 See supra Part III.A.2.b

426 ADC, supra note 1, art. 2(9)

427 Id. art. 17.

428 PINKNEY, supra note 41 , at 12

429 See supra Parts I, III.A.

430 See supra Part III.E
} 
areas of democracy. ${ }^{431}$ Notwithstanding the expansive provisions contained in the $\mathrm{ADC}$, the failure of the earlier instruments adopted by the $\mathrm{AU}$ to promote democracy illustrates that the AU must obtain widespread state ratification of the ADC and effectively use and enforce the provisions of the ADC, as democracy in Africa cannot be achieved simply by the adoption of a new regional instrument. Many of the instruments previously adopted by the AU failed to promote democracy because binding instruments were not ratified by member states and the documents either lacked appropriate enforcement mechanisms or the AU failed to apply the enforcement mechanisms established by those earlier instruments. ${ }^{432}$

Serious challenges remain to the establishment of widespread democracy in Africa, as evidenced by the recent political crises in Egypt, Mali and GuineaBissau. ${ }^{433}$ Both the AU and the OAS, through the adoption of their respective democratic charters and their participation in the OAS-AU Democracy Bridge, have expressed their commitment to promote liberal democratic ideals in the Americas and Africa. The complications encountered by the OAS in Latin America also indicate that democracy requires more than the adoption of a democratic charter. The Nicaraguan crisis, in particular, illustrates that the adoption of a regional democratic charter will not automatically lead to democracy without continual and effective enforcement. ${ }^{434}$ Therefore, in implementing the ADC, the $\mathrm{AU}$ should heed the lessons learned by the OAS in its utilization of the $\mathrm{ODC}$, and should timely and effectively apply the enforcement provisions of the $\mathrm{ADC}$, including actively monitoring elections and imposing punitive economic measures where appropriate. Similarly, the Ecuadorian crisis illustrates that the latent problems and local conditions that may hinder the establishment of democracy, such as lack of respect for the rule of law and lack of respect for the independence of the judiciary, must also be resolved to establish viable, long-term democracies. ${ }^{435}$ The AU must also adopt preventative rather than reactionary approaches to promoting democracy. In doing so, the AU must be ready to quickly address actions by member states that destabilize governments, even if such actions have not yet led to an unconstitutional change of government.

\footnotetext{
431 See supra Part III.E.

432 See supro Part II.

433 See supra Part III.A.3

434 See supra Part III.B.3.

435 See supra Part III.B.4.
} 